\author{
UNIVERSIDADE DE SÃO PAULO \\ ESCOLA DE ENFERMAGEM DE RIBEIRÃO PRETO
}

LEILA MARIA GEROMEL DOTTO

Atenção Qualificada ao Parto: a realidade da assistência de enfermagem em Rio Branco - AC

Ribeirão Preto

2006 


\title{
Atenção Qualificada ao Parto: a realidade da assistência de enfermagem em Rio Branco - AC
}

\author{
Tese apresentada à Escola de Enfermagem de \\ Ribeirão Preto da Universidade de São Paulo, \\ para obtenção do título de Doutor em \\ Enfermagem. \\ Área de Concentração: Enfermagem em Saúde \\ Pública \\ Linha de pesquisa: Assistência à saúde da mulher \\ no ciclo vital \\ Orientadora: Profa. Dra. Marli Villela Mamede
}


AUTORIZO A REPRODUÇÃO E DIVULGAÇÃO TOTAL OU PARCIAL DESTE TRABALHO, POR QUALQUER MEIO CONVENCIONAL OU ELETRÔNICO, PARA FINS DE ESTUDO E PESQUISA, DESDE QUE CITADA A FONTE.

\section{FICHA CATALOGRÁFICA}

Dotto, Leila Maria Geromel

Atenção Qualificada ao Parto: a realidade da assistência de enfermagem em Rio Branco - AC. Ribeirão Preto, 2006. 148p.

Tese de Doutorado, apresentada à Escola de Enfermagem de Ribeirão Preto/USP - Área de concentração: Enfermagem em Saúde Pública.

Orientadora: Mamede, Marli Villela.

1. Enfermagem obstétrica. 2. Equipe de enfermagem. 3. Parto. 4. Competência profissional. 


\section{FOLHA DE APROVAÇÃO}

Leila Maria Geromel Dotto

Atenção Qualificada ao Parto: a realidade da assistência de enfermagem em Rio Branco - AC.

Tese apresentada à Escola de Enfermagem de Ribeirão Preto da Universidade de São Paulo, para obtenção do título de Doutor em Enfermagem.

Área de Concentração: Enfermagem em Saúde Pública.

Aprovada em: 2006

\section{BANCA EXAMINADORA}

Profa. Dra. Marli Villela Mamede

Instituição: EERP/USP

Assinatura:

Profa. Dra. Maria José Clapis

Instituição: EERP/USP Assinatura:

Profa. Dra. Maria Antonieta Rubio Tyrrell

Instituição: EEAN/UFRJ Assinatura:

Profa. Dra. Janine Schirmer

Instituição: Enfermagem/UNIFESP Assinatura:

Profa. Dra. Sônia Maria Oliveira de Barros

Instituição: Enfermagem/UNIFESP Assinatura: 
À minha família, meu pai, Hugo, minha mãe, Nadir, minhas irmãs, Vera e Jane, pelo apoio incondicional durante esta trajetória.

Ao meu marido, César, e meu filho, Henrique, pela compreensão, apoio, e estímulo frente aos desafios que permearam esta etapa de nossas vidas. 


\section{Agradecimentos}

À Profa. Dra. Marli Villela Mamede, pela amizade, respeito, confiança, estímulo, e pela preciosa orientação. Muito obrigada pela oportunidade de compartilhar seu conhecimento em pesquisa e em enfermagem obstétrica, pela forma competente e segura que conduziu este trabalho.

Aos docentes das disciplinas de pós-graduação, pela experiência e conhecimentos compartilhados, e pelos momentos de construção coletiva.

Às colegas da pós-graduação, pelas novas amizades, pelos bons momentos de convívio, de aprendizagem conjunta, pelas experiências compartilhadas, nunca esquecerei.

Às docentes da área de saúde da mulher, pela adorável acolhida, e aos funcionários desta escola, pela atenção e prontidão, com que me atenderam.

À equipe de enfermagem, participante deste estudo, pela excelente receptividade e disponibilidade.

Às parturientes, por consentirem a observação dos cuidados prestados a elas.

À todas as pessoas que contribuíram, de forma direta ou indireta, nesta caminhada, o meu muito obrigada. 


\section{Resumo}

DOTTO, L. M. G. Atenção qualificada ao parto: a realidade da assistência de enfermagem em Rio Branco - AC. 2006. 148 f. Tese (Doutorado em Enfermagem) - Escola de Enfermagem de Ribeirão Preto, Universidade de São Paulo. Ribeirão Preto, 2006.

Tem havido consenso de que a atenção qualificada ao parto e nascimento é uma intervenção fundamental para tornar as gestações e partos mais seguros, visto que apenas $53 \%$ das mulheres em países em desenvolvimento são atendidas no parto por pessoal qualificado. As evidências epidemiológicas mostram que existe uma relação entre a atenção qualificada ao parto e o declínio da mortalidade materna. Este estudo buscou conhecer a realidade do atendimento a parturientes, realizado pela enfermagem nas maternidades do município de Rio Branco-AC. Objetivos: identificar e descrever o perfil dos profissionais de enfermagem que atuam na atenção ao trabalho de parto e parto normal, e analisar as competências essenciais desenvolvidas por eles nesta prática. Metodologia: estudo descritivo, com abordagem quantitativa, realizado em duas maternidades. A população estudada foi composta por 30 profissionais de enfermagem (02 enfermeiras, 07 enfermeiras obstétricas, 08 técnicas de enfermagem e 13 auxiliares de enfermagem). A coleta de dados foi realizada por meio de entrevistas e observações sistemáticas das competências essenciais em obstetrícia. Foram observados 14 admissões, 34 evoluções de trabalho de parto, 11 partos normais e 11 pósparto. A estatística descritiva e o teste exato de Fisher foram usados para análise dos dados. Resultados: perfil dos profissionais: a média de idade dos profissionais foi de 41 anos, 50\% casados ou com parceria fixa, 60\% com mais de 10 anos de formação profissional, com uma média de 130 meses de experiência na assistência ao parto, com carga horária média semanal de trabalho de 63,37 horas, e $40 \%$ deles trabalham em mais de uma instituição, apenas 05 (16,66\%) não realizam parto. Daqueles que realizam parto normal, 18 (72\%) receberam treinamento informal para realizar o parto, acompanhando ou sendo acompanhado por outro profissional, durante a jornada de trabalho, os demais - 07 (28\%) - são enfermeiras obstétricas que foram capacitadas por meio de programas de pós-graduação lato sensu. O tempo de treinamento daquelas sem capacitação formal variou de 10 dias a dois anos. Os resultados revelam que apenas 28\% dos profissionais são considerados qualificados para a atenção ao parto. As competências essenciais: várias práticas obstétricas recomendadas pela OMS são adotadas pelas instituições, enquanto outras não. Muitas das habilidades essenciais em obstetrícia deixaram de ser desenvolvidas ou, quando realizadas, aconteceram de forma incompleta. O modelo de divisão de trabalho para o desempenho das competências obstétricas de maior complexidade nas instituições estudadas mostrou diferenças significantes, revelando que a delegação de tais tarefas está mais na dependência da categoria profissional do que na qualificação profissional para o seu desempenho. Conclusões: de acordo com os critérios e requisitos estabelecidos pelas políticas internacionais sobre o atendimento qualificado ao parto, a realidade revela carência de pessoal qualificado. O modelo de atenção é caracterizado por uma divisão de trabalho que não privilegia a qualificação profissional. Muitas das competências essenciais em obstetrícia não estão sendo contempladas. Revelando, portanto, a necessidade de investimentos na formação de profissionais e na reorganização da assistência, para que se possa realmente modificar a realidade da atenção materna e neonatal no Norte do país.

Palavras-chaves: equipe de enfermagem, parto, enfermagem obstétrica, competência profissional. 


\begin{abstract}
DOTTO, L. M. G. Qualified attention to delivery: the reality of nursing assistance in Rio Branco - AC. 2006. 148 f. Thesis (Nursing Doctorate) - Ribeirão Preto School of Nursing, University of São Paulo, Ribeirão Preto, 2006.
\end{abstract}

There is a consensus that qualified attention to birth and delivery is a fundamental intervention that makes both pregnancy and delivery safer. This is a fact, if it is considered that only 53\% of women in developing countries are assisted by qualified professionals at the moment of delivery. Epidemiologic evidence shows that there is a relationship between qualified assistance to delivery and decrease in maternal mortality. This study aimed to describe the reality of the nursing assistance offered to parturients at hospital birth centers in the city of Rio Branco, Acre, Brazil. Goals: identify and describe the profile of nursing professionals who assist women in labor and natural delivery, and analyze the essential competences developed by those professionals in their practice. Method: a descriptive study using quantitative approach, performed at two hospital birth centers. The studied population was composed of 30 nursing professionals ( 2 nurses, 7 obstetric nurses, 8 nurse technicians and 13 nursing assistants). Data collection was done through interviews and systematic observations of the essential competences in obstetrics. The following situations were observed: 14 admissions, 34 labors, 11 natural deliveries, and 11 postpartum. Data analysis was done using descriptive statistics and Fisher exact test. Results: profile of the nursing professionals: average age of 41 years; $50 \%$ married or in a stable relationship; $60 \%$ have over 10 years of professional experience with an average of 130 months of experience in delivery assistance; average weekly work load of 63.37 hours; $40 \%$ worked in more than one institution; only 5 individuals (16.66\%) did not perform delivery. Of those who perform natural deliveries, 18 (72\%) received informal training and are therefore observed or helped by another health professional. Informal training time ranged from 10 days to 2 years. The other 7 individuals (28\%) are obstetric nurses who received training in graduate programs (specialization). Results show that only $28 \%$ of nursing professionals are considered qualified enough to provide delivery assistance. The institutions adopt some of the WHO obstetric recommendations but fail to adopt others. Several essential obstetric skills are not performed, or, if performed, they are followed incompletely. The model of division of work adopted by the studied institutions to perform high complexity obstetric skills showed significant differences, and revealed that delegating such tasks is more linked to the professional category than to professional qualification. Conclusions: based on the criteria and requirements established by international policies on qualified delivery assistance, the reality shows a need for qualified professionals. The model of attention is characterized by a division of work that does not privilege professional qualification. Many essential obstetric competences are not being followed. Therefore, there is a need to invest in professional training and to reorganize the offered assistance in order to improve the reality of maternal and neonatal attention in Northern Brazil.

Keywords: nursing team, delivery, obstetric nursing, professional competence 


\section{Resumen}

DOTTO, L. M. G. Atención calificada al parto: la realidad de la atención de la enfermaría en Rio Branco - AC. 2006. 148 páginas. Tesis (Doctorado en Enfermería) - Escuela de Enfermería de Ribeirão Preto, Universidad de São Paulo, Ribeirão Preto, 2006.

Existe el consenso de que la atención calificada al parto y nacimiento es una intervención fundamental para tornar las gestaciones y partos más seguros, debido a que apenas el $53 \%$ de las mujeres en países en desarrollo son atendidas en el parto por personas calificadas. Las evidencias epidemiológicas muestran que existe una relación entre la atención calificada al parto y la disminución de la mortalidad materna. Este estudio se dedicó a conocer la realidad de la atención a parturientas, realizado por la enfermería en las maternidades del municipio de Rio Branco-AC. Objetivos: identificar y describir el perfil de los profesionales de enfermería que actúan en la atención al trabajo de parto y al parto normal, y analizar las competencias esenciales desarrolladas por ellos en esta práctica. Metodología: estudio descriptivo realizado en dos maternidades con un abordaje cuantitativo,. La población estudiada estaba compuesta por 30 profesionales de enfermería (02 enfermeras, 07 enfermeras obstetras, 08 técnicas de enfermería y 13 auxiliares de enfermería). La colecta de datos fue realizada por medio de entrevistas y observaciones sistemáticas de las competencias esenciales en obstetricia. Fueron observadas 14 admisiones, 34 evoluciones de trabajo de parto, 11 partos normales y 11 posparto. La estadística descriptiva y la prueba exacta de Fisher fueron usadas para el análisis de los datos. Resultados: perfil de los profesionales: la media de edad de los profesionales fue de 41 años, el 50\% eran casados o con pareja fija, el 60\% tenía más de 10 años de formación profesional, con una media de 130 meses de experiencia en la asistencia al parto, con una carga horaria media semanal de trabajo de 63.37 horas, y $40 \%$ de ellos trabajan en más de una institución, apenas 05 (16,66\%) no realizan parto. De aquellos que realizan parto normal, 18 (72\%) recibieron entrenamiento informal para realizar el parto, acompañando o siendo acompañado por otro profesional, durante la jornada de trabajo, los demás - 07 (28\%) - son enfermeras obstetras que fueron capacitadas por medio de programas de post graduación lato sensu. El tiempo de entrenamiento de aquellas sin capacitación formal varió de 10 días a dos años. Los resultados revelan que apenas el 28\% de los profesionales son considerados calificados para la atención al parto. Las competencias esenciales: varias prácticas obstétricas recomendadas por la OMS son adoptadas por las instituciones, mientras otras no. Muchas de las habilidades esenciales en obstetricia dejaron de ser desarrolladas o cuando eran ejecutadas se realizaron de forma incompleta. El modelo de división de trabajo para el desempeño de las competencias obstétricas de mayor complejidad en las instituciones estudiadas mostró diferencias significativas, revelando que delegar tales tareas depende más de la dependencia de la categoría profesional que de la calificación profesional para su desempeño. Conclusiones: de acuerdo con los criterios y requisitos establecidos por la política internacional sobre la atención calificada al parto, la realidad revela carencia de personal calificado. El modelo de atención se caracteriza por una división de trabajo que no privilegia la calificación profesional. Muchas de las competencias esenciales en obstetricia no están siendo contempladas. Revelando, por tanto, la necesidad de inversiones en la formación de profesionales y en la reorganización de la asistencia, para que se pueda realmente modificar la realidad de la atención materna y neonatal en el Norte del país.

Palabras claves: equipo de enfermería, parto, enfermería obstetra, competencia profesional. 


\section{LISTA DE TABELAS}

Tabela 1. Distribuição dos profissionais de saúde das maternidades de Rio Branco (AC), segundo a maternidade. Rio Branco, 2005.

Tabela 2. Distribuição dos profissionais de enfermagem das maternidades de Rio Branco (AC), segundo a idade, estado conjugal e número de filhos. Rio Branco, 2005.

Tabela 3. Distribuição dos profissionais de enfermagem das maternidades de Rio Branco (AC), segundo a renda familiar. Rio Branco, 2005.

Tabela 4. Distribuição dos profissionais de enfermagem das maternidades de Rio Branco (AC), segundo a remuneração na instituição pesquisada. Rio Branco, 2005

Tabela 5. Distribuição dos profissionais de enfermagem das maternidades de Rio Branco (AC), segundo os anos de formação. Rio Branco, 2005.

Tabela 6. Distribuição dos profissionais de enfermagem das maternidades de Rio Branco (AC), segundo o tempo de trabalho na assistência ao parto. Rio Branco, 2005.

Tabela 7. Distribuição dos profissionais de enfermagem das maternidades de Rio Branco (AC), segundo o tipo de treinamento para realizar partos. Rio Branco, 2005.

Tabela 8. Distribuição dos profissionais de enfermagem das maternidades do município de Rio Branco (AC), segundo os cursos de atualização realizados nos últimos cinco anos. Rio Branco, 2005.

Tabela 9. Distribuição de freqüências das atividades realizadas pelos profissionais de saúde das maternidades de Rio Branco (AC), segundo a categoria profissional, durante a admissão de 14 gestantes observadas. Rio Branco, 2005.

Tabela 10. Distribuição de freqüências das atividades, ausculta do BCF, toque vaginal e diagnóstico de trabalho de parto, realizados pelos profissionais de saúde das maternidades de Rio Branco (AC), segundo a categoria profissional, durante a admissão de 14 gestantes observadas. Rio Branco, 2005.

Tabela 11. Distribuição de freqüências das atividades realizadas pelos profissionais de saúde das maternidades de Rio Branco (AC), segundo a categoria profissional, durante a assistência ao trabalho de parto de 34 parturientes observadas. Rio Branco, 2005. 
Tabela 12. Distribuição de freqüências dos procedimentos, ausculta do BCF, toque vaginal e amniotomia, realizados pelos profissionais de saúde das maternidades de Rio Branco (AC), segundo a categoria profissional, durante a assistência ao trabalho de parto de 34 parturientes observadas. Rio Branco, 2005

Tabela 13. Distribuição de freqüências dos partos realizados pelos profissionais de saúde das maternidades de Rio Branco (AC), segundo a categoria profissional. Rio Branco, 2005.

Tabela 14. Distribuição de freqüências das atividades realizadas pelos profissionais de saúde das maternidades de Rio Branco (AC), durante a assistência ao parto (período expulsivo) das 11 parturientes observadas. Rio Branco, 2005.

Tabela 15. Distribuição de freqüências das atividades realizadas pelos profissionais de saúde das maternidades de Rio Branco (AC), durante a assistência ao parto (dequitação) das 11 parturientes observadas. Rio Branco, 2005.

Tabela 16. Distribuição de freqüências das atividades realizadas pelos profissionais de saúde das maternidades de Rio Branco (AC), durante a assistência ao pós-parto das 11 puérperas observadas. Rio Branco, 2005.

Tabela 17. Distribuição de freqüências das atividades realizadas pelos profissionais de saúde das maternidades de Rio Branco (AC), durante a assistência aos 11 recém-nascidos dos partos observados. Rio Branco, 2005 


\section{LISTA DE FIGURAS}

Figura 1. Média da remuneração salarial dos profissionais de enfermagem das maternidades de Rio Branco (AC)

Figura 2. Distribuição dos profissionais de enfermagem das maternidades de Rio Branco (AC), segundo o número de empregos. Rio Branco, 2005.................... 


\section{SUMÁRIO}

1. INTRODUÇÃO ............................................................................... 14

1.1 Atenção qualificada ao trabalho de parto e parto ............................ 26

1.2 Pressuposto e questões da pesquisa ............................................... 36

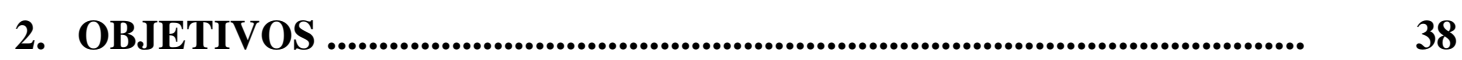

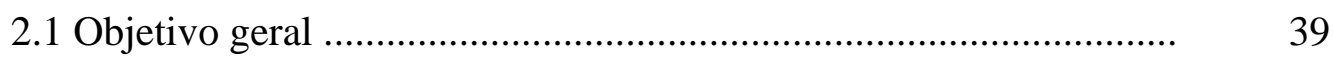

2.2 Objetivos específicos ............................................................... 39

3. METODOLOGIA _................................................................................ 40

3.1 Tipo do estudo ........................................................................ 41

3.2 Local do estudo ... ................................................................... 42

3.2.1 O Estado do Acre .......................................................... 42

3.2.2 Rio Branco ............................................................... 45

3.3 Sujeitos da pesquisa .............................................................. 46

3.4 Aspectos éticos ..................................................................... 47

3.5 Coleta de dados ........................................................................... 47

3.6 Análise dos dados ................................................................ 50

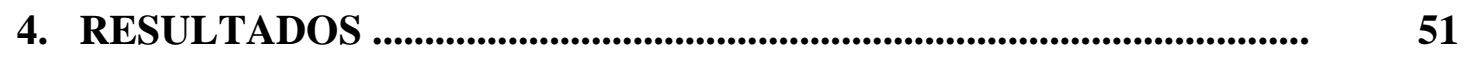

4.1 Caracterização das instituições ................................................... 52

4.1.1 Maternidade "seringueira" .............................................. 52

4.1.2 Maternidade "castanheira” . .......................................... 55

4.2 Caracterização da equipe de enfermagem ..................................... $\quad 60$

4.3 Atenção obstétrica: descrição do observado .................................. 71

4.3.1 A admissão da parturiente ............................................... $\quad 72$

4.3.2 O trabalho de parto .......................................................... $\quad 76$

4.3.3 Atenção ao parto ............................................................. $\quad 80$

4.3.4 Atenção ao pós-parto ......................................................

5. DISCUSSÃO ..................................................................................... 86

5.1 A equipe de enfermagem ........................................................ 87

5.2 As práticas obstétricas .................................................................. 94

6. LIMITAÇÕES E CONCLUSÕES .............................................................. 109

7. IMPLICAÇÕES PARA O ENSINO, PESQUISA E ASSISTÊNCIA .. 112 
REFERÊNCIAS BIBLIOGRÁFICAS .................................................... 114

APÊNDICES ........................................................................................ 122

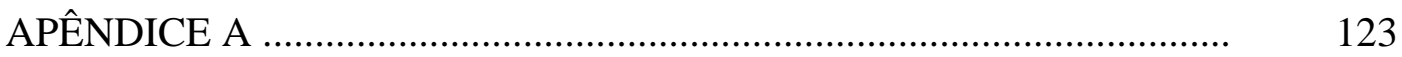

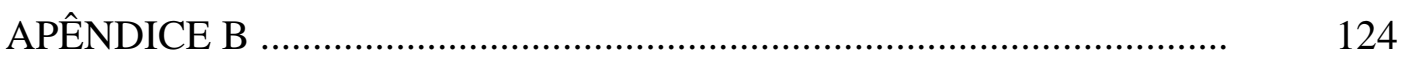

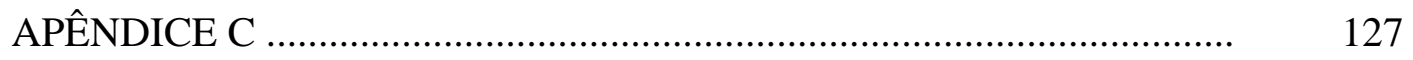

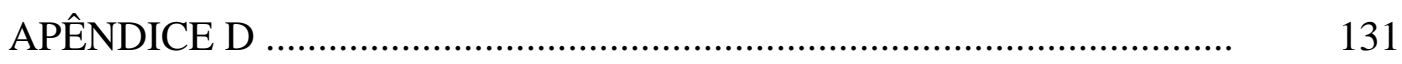

ANEXOS ..................................................................................................... 132

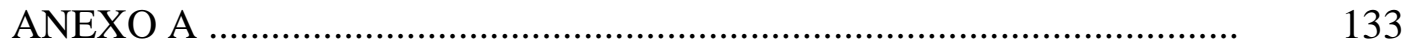

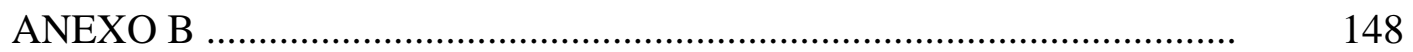


Introdução 


\section{INTRODUÇÃO}

A cada ano, a partir de uma estimativa de 120 milhões de gestações que ocorrem no mundo, morrem aproximadamente 600.000 mulheres com idade entre 15 e 49 anos, vítimas de complicações da gravidez e nascimento, mais de 50 milhões de mulheres sofrem enfermidades ou incapacidades sérias relacionadas ao processo gestação-parto-puerpério que afetam o resto de suas vidas, e pelo menos 1,2 milhão de recém-nascidos morrem por complicações durante o parto. Essa tragédia é ainda maior quando constatamos que estas mulheres morrem durante o período normal do processo reprodutivo e que muitas destas mortes poderiam ser evitadas com medidas preventivas básicas, como a identificação das complicações precocemente, tomada de providências em emergências e atenção qualificada durante o processo da gravidez, parto, nascimento e puerpério (WORLD HEALTH ORGANIZATION. WHO, 1999; MACDONALD; STARRS, 2003a).

Em países em desenvolvimento, uma mulher em 16 pode morrer de complicações relacionadas à gravidez ou nascimento, comparadas a uma em 2.800 gestações em países desenvolvidos. Cada morte ou complicação de longo prazo representa uma tragédia individual para a mulher, para o seu parceiro, para seu filho, sua família e para a comunidade (WHO, 2004a).

As estimativas de mortalidade materna, desenvolvidas pela Organização Mundial de Saúde (OMS), o Fundo das Nações Unidas para a Infância (UNICEF) e pelo Fundo de População das Nações Unidas (FNUAP), indicaram que, no ano de 2000, o número estimado de mortes maternas foi de 529.000 no mundo. Estas mortes estão quase que igualmente divididas entre a África (251.000) e Ásia (253.000), com quase 4\% (22.000) ocorridas na América Latina e Caribe e menos de 1\% (2.500) nas regiões mais desenvolvidas do mundo. Quanto à Razão da Mortalidade Materna (RMM), estima-se que esteja em torno de 400 por 
100.000 nascidos vivos no mundo, nas regiões a RMM mais alta encontra-se na África (830), seguida da Ásia (330), Oceania (240), América Latina e Caribe (190) e pelos países desenvolvidos (20) (WHO, 2003).

As principais causas das mortes maternas são conhecidas, e mais de $80 \%$ delas poderiam ser prevenidas ou poderiam ser evitadas por ações efetivas e disponíveis, até mesmo nos países mais pobres do mundo (WHO, 2004a). Em nível global, a hemorragia, principalmente a hemorragia pós-parto, é a primeira causa de morte materna (25\%), seguida de infecção (15\%), e doenças hipertensivas da gravidez (12\%), principalmente a eclâmpsia (WHO, 1999).

A mortalidade materna é um indicador de disparidade e iniqüidade entre homens e mulheres e sua extensão revela o lugar das mulheres na sociedade e o acesso delas aos serviços sociais, de saúde e nutrição, assim como as oportunidades econômicas. A mortalidade materna não é apenas uma “desvantagem da saúde” ela é uma “desvantagem social” (WHO, 1999, p. 2).

No Brasil, os índices elevados da mortalidade materna constituem-se em motivo de preocupação das autoridades de saúde em nível federal, estadual e municipal. Segundo o Ministério da Saúde (BRASIL. MS., 2004a), a razão da mortalidade materna no país, em 2002, foi de 50,3 por cem mil nascidos vivos, este valor não foi muito diferente nas regiões nacionais. A região Nordeste teve o maior índice com 60,8, seguida da região Centro-Oeste com 60,3, depois da região Sul com 56,6, a Norte com 53,2 e o menor índice foi encontrado na região Sudeste com 45,9.

Pelos métodos demográficos, estima-se que a cobertura do sistema de informação sobre mortalidade, gerido pelo Ministério da Saúde, seja de cerca de 85\%, a subinformação concentra-se quase que exclusivamente nas regiões Norte e Nordeste. No entanto, mesmo nas regiões com boa cobertura, sabe-se que a declaração de uma causa materna como causa 
mortis não é totalmente exata no país (LAURENTI; JORGE; GOTLIEB, 2004). Portanto, a real magnitude da mortalidade materna em nosso país não está nos números oficiais, assim como em todos os países em desenvolvimento que também apresentam dificuldades para identificar estes números, e até mesmo em países desenvolvidos que também referem problemas, em menor grau, para captar todos os óbitos maternos (WHO, 2003).

Em 2002, foi realizada uma pesquisa em 25 capitais brasileiras e Distrito Federal, onde a estimativa da razão da mortalidade materna encontrada no conjunto das capitais foi de 54,3 por cem mil nascidos vivos. Para as regiões, através do conjunto das capitais, encontrouse a maior estimativa na região Nordeste $(73,2)$, seguida da região Norte $(60,5)$, depois num patamar mais abaixo vem a região Centro-Oeste $(49,3)$, Sudeste $(45,4)$ e Sul $(42,0)$. Esse estudo identificou as causas das mortes maternas e encontrou que $67,1 \%$ foram decorrentes de causas obstétricas diretas, ou seja, foram aquelas devido a complicações de causa ou estados que só ocorrem no ciclo gravídico puerperal. Os transtornos hipertensivos predominaram entre as causas com $24,9 \%$. Complicações do trabalho de parto e do parto foram a causa de 10,4\% das mortes maternas. As complicações hemorrágicas, principalmente devido à placenta prévia e ao descolamento prematuro da placenta, foram responsáveis por 9,0\% do total das mortes. Os pesquisadores investigaram os óbitos de mulheres de 10 a 49 anos e encontraram que além das 144 declarações oficiais de óbito com causa materna, havia mais 95 que não tinham sido declaradas como mortes maternas (LAURENTI; JORGE; GOTLIEB, 2004).

Gomes, Mamede e Costa-Junior (2004) realizaram um estudo nos Estados de São Paulo, Paraná, Pará, Ceará e Mato Grosso, nos anos de 1999 e 2000, para identificação das mortes maternas não registradas e/ou mascaradas por meio do Sistema de Informações Hospitalares do Sistema Único de Saúde (SIH-SUS). Nesse período, o Sistema registrou 596 mortes maternas nestes Estados, os pesquisadores encontraram mais 55 casos de mortes de mulheres, em idade reprodutiva, que deveriam estar informadas como morte materna, 
totalizando 651 óbitos maternos. Dos 55 casos, 39 foram identificados pelos procedimentos obstétricos e 16 foram pelos diagnósticos secundários, revelando a fragilidade dos dados oficiais.

As primeiras estimativas da extensão da mortalidade materna no mundo foram realizadas na década de 1980, quando a situação alarmante que as mulheres estavam vivenciando tornou-se pública. A mortalidade por complicações na gravidez e no nascimento era pouco conhecida e era um problema seriamente negligenciado. Diante dessa realidade, as Agências Internacionais de Desenvolvimento lançaram em 1987, na conferência de Nairobi, no Quênia, a Iniciativa por uma Maternidade Segura (ISM). O Grupo Interagencial que lidera este movimento é composto pelo UNICEF, FNUAP, OMS, Banco Mundial, Federação Internacional da Paternidade Planejada (IPPF), Conselho da População, Maternidade Segura do Nepal, Programa Regional de Prevenção de Mortalidade Materna (África), Federação Internacional de Ginecologia e Obstetrícia (FIGO) e Confederação Internacional das Parteiras (ICM) (SAFE MOTHERHOOD, 1998).

O principal objetivo da conferência foi dar visibilidade para as dimensões e conseqüências das precárias condições de saúde materna nos países em desenvolvimento e mobilizar ações para redução das mortes maternas e enfermidades. A Iniciativa identificou amplas e múltiplas questões na vida e saúde das mulheres que necessitavam ser revisadas nos países em desenvolvimento, com a intenção de reduzir as altas taxas de mortalidade materna em pelo menos 50\% até o ano 2000 e em 75\% até o ano de 2015. Esta iniciativa tem trabalhado para aumentar a consciência e promover ações em nível global e nacional para se conseguir que as gestações e partos sejam mais seguros para as mulheres e os recém-nascidos (MACDONALD; STARRS, 2003a).

A Iniciativa Global tornou-se uma parceria de governos, agências técnicas, organizações não-governamentais e defensores da saúde das mulheres em mais de 100 países. 
Estes parceiros estão trabalhando para proteger a saúde e vidas das mulheres, especialmente durante a gestação e nascimento (SAFE MOTHERHOOD, 1998).

Em 1997, o Grupo Interagencial convocou uma nova conferência internacional que aconteceu em Colombo, Sri Lanka, com o objetivo de examinar as lições aprendidas durante o primeiro decênio da Iniciativa, identificar as estratégias mais eficazes e mobilizar ações em nível nacional para implementar estas estratégias. Naquele momento o que já se sabia era que a principal causa de morte e incapacidade entre as mulheres de 15 a 49 anos em países em desenvolvimento eram as complicações da gravidez e nascimento. Sabia-se que toda mulher estaria em risco. Durante a gestação, qualquer mulher poderia vivenciar situações de risco de vida e complicações que necessitam de cuidados médicos imediatos. Sabia-se também que, para reduzir as mortes, os serviços de saúde maternos deveriam estar prontamente disponíveis, deveriam ser utilizados especialmente durante e após o nascimento, e que estes serviços deveriam oferecer provedores de saúde capacitados. Outro consenso que se tirou era que as estratégias do movimento maternidade segura deveriam ser inclusivas, ou seja, todas as mulheres deveriam ter acesso, independente de diferenças sociais, econômicas ou culturais (STARRS, 1998).

Os parceiros de todo o mundo engajados na Iniciativa Maternidade Segura discutiram no Sri Lanka resultados de pesquisas, de novas tecnologias empregadas, de modelos de programas e lições que aprenderam durante a primeira década da Iniciativa. A reunião propôs mensagens essenciais de ação para melhorar a saúde materna, sendo uma delas “assegurar atenção qualificada no parto” e os principais serviços de saúde que deveriam estar disponíveis para se conseguir uma maternidade mais segura. As ações destes serviços estão dirigidas às fases cruciais do desenvolvimento da mulher no período de reprodução, a saber:

1- Durante a gestação - atenção pré-natal e orientações: os trabalhadores de saúde devem orientar as mulheres sobre como permanecerem saudáveis 
durante a gravidez; orientar e preparar as mulheres e suas famílias para o parto; conscientizá-las sobre as possíveis complicações da gravidez. Os trabalhadores de saúde também devem identificar e tratar as complicações precocemente e melhorar a saúde reprodutiva das mulheres e seu bem-estar com medidas preventivas (suplemento de ferro, imunização contra o tétano), identificar e tratar problemas existentes (como doenças sexualmente transmitidas).

2- Durante o nascimento - atenção qualificada durante 0 parto e nascimento: toda mulher dever ser atendida por um profissional de saúde que seja capaz de administrar um parto normal, bem como identificar e administrar complicações como hemorragia, choque e infecção. Os profissionais qualificados devem ter acesso ao atendimento de emergência que funciona e um sistema de transporte que possibilite a transferência das mulheres para uma instituição de saúde adequada ao nível de cuidado médico exigido, como para a realização de parto cesárea ou de transfusão de sangue, quando necessários.

3- Depois do parto - cuidado pós-parto: as mulheres devem ser vistas por trabalhadores de saúde, preferentemente dentro dos três primeiros dias, de forma que qualquer problema (como infecção) possa ser descoberto e ser tratado precocemente. Uma visita pós-parto dentro das primeiras seis semanas depois do parto permite aos trabalhadores de saúde ter a certeza de que a mãe e o bebê estão bem, assim como, orientar e apoiar o aleitamento materno e oferecer informações de serviços de planejamento familiar.

4- Antes e depois da gestação - planejamento familiar: orientar sobre os serviços de planejamento familiar disponíveis a todos os casais e indivíduos, 
inclusive os adolescentes e mulheres solteiras. Os serviços de planejamento familiar devem oferecer informações completas e aconselhar para que se faça uma escolha entre os métodos de contracepção possíveis.

5- Ao longo da vida reprodutiva - cuidados relacionados ao aborto: serviços de alta qualidade para tratar e administrar complicações de aborto inseguro devem estar disponíveis em todo o sistema de saúde. Estes serviços requerem: pessoal treinado e autorizado para tratar complicações; equipamentos apropriados; protocolos para o cuidado; e rede de referência efetiva. Mulheres com complicações de aborto também devem ter acesso a outros serviços de saúde reprodutiva, inclusive planejamento familiar. Nos países em que o aborto é legalizado, serviços seguros para interromper a gravidez e aconselhamento devem estar disponíveis. Os trabalhadores de saúde devem ser informados sobre os protocolos e legalidade do aborto. Tecnologias apropriadas, incluindo métodos novos como aborto nãocirúrgico, devem estar disponíveis onde for possível.

6- Durante a adolescência - serviços e educação em saúde reprodutiva: todas as pessoas jovens devem ter informação sobre sexualidade, reprodução e contracepção para ajudá-las a tomar decisões informadas sobre sexualidade e a negociar abstinência ou sexo mais seguro com os parceiros. Aconselhamento sobre saúde reprodutiva que seja sensível, respeitoso e confidencial. Os serviços para adolescentes casados e solteiros devem enfatizar a prevenção de gravidez não desejada, de aborto inseguro e doenças sexualmente transmitidas.

7- Para as mulheres e famílias - educação da comunidade: tópicos de saúde fundamentais para as mulheres e suas famílias que incluam como prevenir 
gravidez não desejada e como evitar aborto inseguro, como reconhecer complicações de gravidez, parto e aborto inseguro e onde buscar tratamento. Devem estar disponíveis tópicos que exponham os perigos de certas práticas tradicionais durante a gravidez e o parto. Também é necessária a educação de pessoas que ajudam na tomada de decisão, como os maridos, líderes da comunidade, e também políticos para promover a maternidade segura e melhorar a saúde das mulheres (SAFE MOTHERHOOD, 1998).

Da conferência no Sri Lanka, em 1997, surgiu também um forte consenso sobre o valor da atenção qualificada durante o parto como uma intervenção fundamental para tornar as gestações e partos mais seguros. Os dados mostram que apenas 53\% das mulheres dos países em desenvolvimento são atendidas no parto por pessoal qualificado. Como meta geral, recomenda-se que deve se dispor de uma pessoa qualificada para cada 200 nascimentos anuais, porém em alguns países em desenvolvimento encontra-se uma pessoa qualificada para cada 15.000 nascimentos. Essa escassez é particularmente grave nas zonas rurais, pelo fato de os profissionais de saúde estarem concentrados nas cidades (MACDONALD; STARRS, 2003b).

Numa pesquisa realizada por regiões, identificou-se que a porcentagem de partos atendidos por uma pessoa qualificada é de 99\% na América do Norte, 98\% na Europa, 75\% na América Latina e Caribe, 53\% na Ásia, 52\% na Oceania e 42\% na África (WHO, 1996).

Atenção qualificada, durante a gravidez, parto e pós-parto imediato, é entendida como:

O processo pelo qual uma mulher grávida e seu bebê recebem os cuidados adequados durante a gravidez, o trabalho de parto, o parto e o período pósparto e neonatal, independente do parto ser no domicílio, no centro de saúde ou no hospital. Para que isto ocorra, o provedor deve ter habilidades necessárias além de contar com um contexto facilitador em vários níveis do sistema de saúde. Isto inclui um marco de políticas e normas, medicamentos 
e materiais, equipamentos e infra-estrutura adequados além de um eficiente e efetivo sistema de comunicação, e de referência e transporte (MACDONALD; STARRS, 2003a, p. 6).

Os dados de vários países em desenvolvimento indicam que a mortalidade materna é geralmente mais baixa em países onde existe uma alta proporção de partos atendidos por pessoal qualificado. Baseados nestas informações atuais, os especialistas concordam que a atenção qualificada deve ser o elemento central de qualquer programa que tenha como meta a redução das mortes maternas (MACDONALD; STARRS, 2003b). Assegurar que um trabalhador de saúde com habilidades obstétricas esteja presente em cada nascimento, e que o transporte esteja disponível em caso de urgência, tornou-se a principal meta recomendada na conferência do Sri Lanka para o alcance de uma maternidade sem risco para todas as mulheres (STARRS, 1998).

Por outro lado, os profissionais de saúde podem carecer de destrezas necessárias para salvar a vida de mulheres que apresentam complicações graves. Aproximadamente 15\% das mulheres grávidas vivenciam uma complicação que ameaça sua vida durante a gestação e o parto. Preocupados com a qualificação destes profissionais, a Confederação Internacional das Parteiras (ICM), a OMS e a Federação Internacional de Ginecologia e Obstetrícia (FIGO) delinearam os conhecimentos, habilidades e comportamentos que os provedores de saúde devem possuir para realizar a prática obstétrica, para isso, realizaram um amplo estudo entre 1995 e 2001, com representantes de 17 países de cinco regiões (África, Américas, Europa e Ásia/Pacífico). Desse estudo resultou, em 2002, a declaração do ICM sobre Competências Essenciais para o Exercício Básico da Obstetrícia (FURLLERTON et al., 2003).

Desde a conferência de Nairobi, várias instâncias internacionais e nacionais têm fixado metas para redução da mortalidade materna e a expansão da atenção qualificada, durante o parto. Em 2000, no maior encontro de líderes de Estados das Nações Unidas foi adotada a Declaração do Milênio. Este acordo entre as nações inclui oito objetivos críticos 
que são os Objetivos de Desenvolvimento do Milênio para combater a pobreza e acelerar o desenvolvimento humano. Nestes objetivos está inclusa a meta para a redução da mortalidade materna em 75\% entre 1990 e 2015. A declaração identifica a proporção de nascimentos atendidos por pessoal qualificado como um indicador para esta meta (WHO, 2004b).

Mais recentemente na 26a Conferência Sanitária Pan-Americana realizada em setembro de 2002, uma de suas resoluções foi a "Estratégia regional para a redução da mortalidade e morbidade maternas” que solicita aos Estados-membros a adoção da meta da Declaração do Milênio sobre redução das mortes maternas, que apóiem as intervenções baseadas em provas científicas para reduzir a mortalidade e morbidade maternas, como aquelas relacionadas aos Cuidados Obstétricos Essenciais e à assistência ao parto por pessoal qualificado, entre outras (ORGANIZAÇÃO PAN-AMERICANA DE SAÚDE. OPAS, 2002).

Há alguns anos, o Brasil vem tentando implantar e implementar ações na tentativa de reduzir a mortalidade e morbidade maternas e melhorar as condições de saúde da mulher. Assim o Ministério da Saúde em parceria com instituições e associações, como a Federação Brasileira de Ginecologia e Obstetrícia (FEBRASGO) e a Associação Brasileira de Obstetrizes e Enfermeiros Obstetras (ABENFO), vêm trazendo à pauta de suas discussões a problemática relacionada à assistência materna e neonatal, na tentativa de reduzir a morbimortalidade, diminuir as intervenções desnecessárias e assegurar uma maternidade sem risco.

A política adotada pelo Ministério da Saúde, por meio de ações programáticas que priorizam a atenção básica e a mudança do modelo assistencial, visando à humanização do parto e nascimento no âmbito do Sistema Único de Saúde (SUS), integra o projeto de trabalho da Área Técnica da Saúde da Mulher (TYRRELL; SANTOS, 2001).

Em 1995, foi criado o Projeto Maternidade Segura, numa parceria entre o Ministério da Saúde, FEBRASGO, Organização Pan-Americana de Saúde (OPAS/OMS) e 
FNUAP. Este projeto propôs oito passos para o alcance da maternidade segura na tentativa de mobilizar os profissionais que atuam direta ou indiretamente nos cuidados da mulher, relacionados à saúde reprodutiva, assim como na assistência à criança para obtenção da eficácia da assistência prestada, e para a redução das morbimortalidades materna e infantil (FEBRASGO, 1995).

O Ministério da Saúde, em 1999, estabeleceu, por recomendação da $23^{a}$ Conferência Sanitária Pan-Americana, que um sistema de vigilância epidemiológica da morte materna seja implantado em cada município (REDE FEMINISTA DE SAÚDE, 2003). No entanto, a partir de 1987 já começava o desenvolvimento dos comitês de morte materna, apesar deste movimento ganhar maior dimensão chegando a todos os Estados no período de 1993 e 1996. Dentre os vários objetivos dos comitês, estabeleceu-se que estes são responsáveis por aumentar a quantidade e qualidade do conhecimento disponível sobre os níveis da morte materna, suas causas e os fatores de risco (BRASIL. MS., 2002).

O Programa de Humanização do Pré-Natal e Nascimento - PHPN foi lançado, em 2000, pelo Ministério da Saúde, numa tentativa de buscar a melhoria do acesso, da cobertura e da qualidade do acompanhamento pré-natal. Este programa vincula o início precoce, com os procedimentos e atividades mínimas que devem ser realizados, assim como o número mínimo de consultas pré-natal e a exigência da consulta pós-parto (BRASIL. MS., 2000).

Os municípios que aderirem ao programa ganharão incentivo financeiro por cumprir com todos os requisitos e deverão apresentar no termo de adesão a rede de unidades que atenderá a gestante, assim como os laboratórios de apoio e as maternidades que receberão as gestantes para o parto. A intenção é garantir o vínculo pré-natal/parto, evitando com isso a peregrinação da gestante por uma vaga nas maternidades. É mais uma tentativa na busca pela qualidade e eqüidade.

Entre outras estratégias para o alcance da maternidade segura e especialmente 
para reduzir as cifras de partos cirúrgicos, o Ministério da Saúde, em 1998, passou a publicar dispositivos no sentido de valorizar o papel da enfermeira obstétrica, na assistência ao parto. Assim, a publicação da Portaria n 2.815/98, pelo Ministério da Saúde, veio reforçar o papel desta profissional na assistência obstétrica no momento do parto, ao deliberar a inclusão, na tabela de pagamento do SUS, do parto realizado por enfermeira obstétrica. Como o número de enfermeiras obstétricas era reduzido em nosso país, o Ministério da Saúde em parceria com as Escolas de Enfermagem deram início a um movimento para capacitar enfermeiras para realizar o parto normal, por meio de cursos de especialização em enfermagem obstétrica em todas as regiões do Brasil. Nesse processo, o Comitê de Especialistas de Enfermagem Obstétrica da Área Técnica da Saúde da Mulher do Ministério da Saúde, representado por lideranças nacionais e pela ABENFO, estabeleceu importantes critérios para o desenvolvimento de projetos de capacitação de enfermeiras obstétricas no país (TYRRELL; SANTOS, 2001). Esse projeto teve início em 1999 e continua em 2005. Já foram realizados 77 cursos, com a formação de 1.333 enfermeiras obstétricas (SCHIRMER, 2004).

Outra iniciativa foi realizar treinamento das parteiras tradicionais, visto que na região Norte e Nordeste onde a razão da mortalidade materna encontra-se em patamares mais elevados do país, esta profissional ainda é muito solicitada.

Outras medidas que estão sendo tomadas que visam à melhoria da atenção ao parto e nascimento relacionam-se ao incentivo e apoio à criação dos centros de parto normal em todo o país, investimento na qualificação das maternidades que realizam partos e serviços de urgência para atenção às mulheres e aos recém-nascidos, assim como a priorização na capacitação e educação permanente de todos os profissionais envolvidos na atenção obstétrica (BRASIL. MS., 2004a).

Essas são algumas das estratégias que o Ministério da Saúde em parceria com os Estados e municípios vem adotando para a redução dos altos índices de mortalidade e 
morbidade maternas em nosso país. Estas estratégias, contudo, não se desenvolvem e repercutem da mesma forma em todos os Estados. Assim como existem diferenças nos índices de mortes maternas, também existem muitas dificuldades para que as estratégias tenham a mesma resolutividade entre os Estados.

Nesse contexto, onde as mortes maternas continuam sendo um problema a ser combatido, a atenção qualificada ao parto é uma estratégia fundamental para tornar as gestações e partos mais seguros e que pode contribuir significativamente na redução das mortes maternas. Considerando que o profissional de saúde que atende ao parto e nascimento deve possuir competências essenciais (conhecimentos e habilidades) para o exercício da prática obstétrica com qualidade, definimos como objeto deste estudo as competências desenvolvidas pelo pessoal de enfermagem (enfermeiras, enfermeiras obstétricas, obstetrizes, técnicos e auxiliares de enfermagem e parteiras ${ }^{1}$ ) no atendimento à mulher no trabalho de parto e parto, nas maternidades do município de Rio Branco-AC.

De acordo com a Confederação Internacional das Parteiras (ICM), o termo competência é utilizado para referir tanto a ampla declaração encabeçada em cada seção das competências essenciais para o exercício básico da obstetrícia, como ao conhecimento, habilidades e comportamentos básicos requeridos de uma parteira para uma prática segura (INTERNATIONAL CONFEDERATION OF MIDWIVES, 2002).

\subsection{Atenção qualificada ao trabalho de parto e parto}

A maioria das gestações e partos transcorre sem incidente, no entanto todas as gestações representam risco. Em torno de 15\% do total de mulheres grávidas manifestam alguma complicação potencialmente mortal que requer atenção qualificada, e, em alguns

\footnotetext{
${ }^{1}$ Profissional da equipe de enfermagem ou não que recebeu treinamento informal para realizar parto normal em instituição de saúde.
} 
casos, uma intervenção obstétrica acertada e segura pode salvar suas vidas. Uma mulher que apresenta uma complicação obstétrica que pode chegar a ser mortal se encontra em uma situação de emergência que requer diagnóstico e manejo imediatos (WHO, 2000).

Viggiano et al. (2004), ao investigarem o universo de 4.560 partos, 3.051 abortamentos, 172 casos de gestações ectópicas e 153 casos de mola hidatiforme que ocorreram numa maternidade pública terciária de Goiânia-GO, encontraram 86 transferências de mulheres (gestantes e puérperas) para unidades de tratamento intensivo. Estas mulheres eram 52,3\% nulíparas, 73,3\% pertenciam à faixa etária dos 19-35 anos, a cesariana foi o parto de $72,4 \%$ delas, $81,4 \%$ foram transferidas durante o período puerperal e as causas obstétricas responderam por 82,6\% das indicações de transferências. Os distúrbios hipertensivos induzidos pela gestação representaram mais da metade $(57,7 \%)$ das indicações obstétricas, sendo a eclâmpsia a responsável por metade delas. As doenças hemorrágicas, tendo o descolamento prematuro de placenta como a principal causa, responderam por $19,7 \%$ das indicações. A infecção pós-aborto e a infecção puerperal dividiram quase que igualmente as causas por infecção que representaram 9,8\% das transferências das mulheres para unidades de terapia intensiva.

Diante dos achados, os autores enfatizam a importância dos profissionais estarem atentos às mulheres nulíparas, geralmente jovens que estão iniciando suas vidas reprodutivas, e com o desfecho determinado pelas síndromes hipertensivas induzidas pela gestação, complicação obstétrica que continua requerendo preocupação e competência do profissional. Salientam que o acompanhamento pré-natal adequado, reconhecimento dos primeiros sinais de complicação, o referenciamento oportuno dos casos mais graves e conhecimento das condutas terapêuticas emergenciais são essenciais para se minimizar este grave problema da obstetrícia brasileira (VIGGIANO et al., 2004).

Nas últimas décadas, ocorreu uma rápida expansão no desenvolvimento e uso de 
uma variedade de práticas para iniciar, ou corrigir a dinâmica uterina, como também, acelerar, regular ou monitorar o processo fisiológico do parto, com o objetivo de obter melhores resultados para a mulher e seu recém-nascido. Muitas vezes, acreditando-se oferecer a melhor assistência, adotou-se uma variedade de intervenções inúteis, inadequadas e/ou desnecessárias, e freqüentemente mal avaliadas. Diante dessa situação, a OMS (ORGANIZAÇÃO MUNDIAL DE SAÚDE. OMS, 1996) publicou um guia prático de assistência ao parto normal, onde foram identificadas as práticas mais comumente utilizadas durante o trabalho de parto e parto, e estabeleceram-se, com base em evidências científicas, normas de boas práticas para a condução do trabalho de parto sem complicações.

Esse guia classificou suas recomendações sobre as práticas relacionadas ao parto normal em quatro categorias: A) práticas demonstradamente úteis e que devem ser estimuladas, B) práticas claramente prejudiciais ou ineficazes e que devem ser eliminadas, C) práticas em relação às quais não existem evidências suficientes para apoiar uma recomendação clara e que devem ser utilizadas com cautela, até que mais pesquisas esclareçam a questão e D) práticas freqüentemente utilizadas de modo inadequado.

O grande desafio do cuidado materno é a sua imprevisibilidade, especialmente na hora do parto. Complicações que podem colocar a mulher e o recém-nascido em risco de vida surgem de repente, portanto, a presença de um profissional qualificado é essencial para assegurar que as complicações sejam administradas adequadamente (STARRS, 1998).

A mulher necessita de um cuidado contínuo durante a gravidez para assegurar as melhores condições de saúde possíveis para ela e para seu recém-nascido. Este cuidado deve ter início em sua própria casa, através do autocuidado e da prevenção, seguido do cuidado oferecido a nível primário (posto de saúde, unidades de saúde da família, casas de parto). Se a gravidez, o nascimento e o período pós-natal permanecerem livres de complicações, a mulher pode continuar recebendo cuidados em nível primário, contudo, quando as complicações 
ocorrem, a mulher e/ou seu recém-nascido necessitam de cuidados em níveis secundários e terciários do sistema de saúde, dependendo da gravidade de sua respectiva condição (WHO, 2004b).

O fornecimento de cuidado contínuo requer um sistema de saúde funcionando com infra-estrutura necessária em cada local, incluindo transporte entre o nível primário e os demais níveis. Também são necessárias a colaboração e a eficiência entre todos os envolvidos neste processo.

A pessoa qualificada deve estar no centro do cuidado contínuo, no nível primário, ela necessitará trabalhar com outros provedores de cuidado da comunidade, tais como as atendentes tradicionais do parto, agentes comunitários de saúde e trabalhadores sociais. Ela também necessitará de fortes ligações de trabalho com os provedores de saúde dos níveis secundários e terciários do sistema de saúde para que a mulher e seu recém-nascido possam realmente receber cuidado contínuo de saúde durante a gravidez, o nascimento e o período pós-parto.

O Grupo Interagencial que coordena a Iniciativa Maternidade Segura recomenda que para se oferecer atenção qualificada, durante o parto, a todas as mulheres do mundo é essencial adotar as seguintes medidas:

1- Definir indicadores de referência nacional para monitorar o progresso em direção à meta de oferecer atenção qualificada a todos os partos;

2- Elaborar políticas nacionais que garantam o direito de toda mulher receber atenção qualificada;

3- Implementar estratégias nacionais para capacitar um número suficiente de novos profissionais qualificados e atualizar as destrezas e conhecimentos dos que já estão trabalhando; 
4- Estabelecer normas e diretrizes nacionais destinadas a monitorar o desempenho do pessoal qualificado;

5- Investir em medidas concretas para conseguir que os sistemas de saúde existentes possam oferecer apoio à atenção qualificada ao parto, incluindo abastecimento de medicamento, sistema de comunicação e transporte entre as instituições de saúde; e

6- Eliminar barreiras financeiras, culturais e outros obstáculos que possam impedir que todas as mulheres recebam atenção qualificada no parto (MACDONALD; STARRS, 2003b).

A OMS define que um profissional qualificado para o nascimento pode ser uma parteira profissional ${ }^{2}$, uma enfermeira com especialização em obstetrícia, ou médico com especialização e experiência específica. As parteiras tradicionais da comunidade não são classificadas como profissionais qualificadas (STARRS, 1998).

Um profissional qualificado é aquele que recebeu uma formação, treinou e atingiu proficiência nas habilidades necessárias para manejar a gestação normal, o parto e o período do pós-parto imediato e na identificação, manejo e referência de complicações nas mulheres e nos recém-nascidos (WHO, 2004b).

Para que o profissional de saúde (quer seja parteira profissional, enfermeira ou médico) possa dar uma atenção eficaz e de boa qualidade, ele deve ter uma variedade de habilidades específicas, podendo exercê-las de forma competente. É fundamental também que este profissional qualificado esteja autorizado a realizar todos os procedimentos para os quais tenha sido capacitado, podendo, assim, manter sua destreza atualizada bem como oferecer uma atenção que satisfaça às necessidades das mulheres a quem presta os serviços. Além da

\footnotetext{
${ }^{2}$ No Brasil, a parteira profissional corresponde à obstetriz, profissional com curso de graduação com formação específica ao cuidado obstétrico.
} 
competência profissional, ele deve ter respaldo legal e normativo para atuar, deve possuir também acesso a equipamentos e medicamentos essenciais, um sistema de referência em funcionamento e um sistema de educação e de saúde que incentivem o pensamento crítico, a competência clínica e o desenvolvimento de habilidades interpessoais e de comunicação eficazes (MACDONALD; STARRS, 2003a).

Para Maclean (2003), a educação do profissional qualificado e o ambiente de sua prática são fatores primordiais na busca pela capacitação efetiva do profissional para a atenção qualificada. A educação deste profissional deve enfocar as competências que devem ser trabalhadas de acordo com a realidade de cada país. No meio ambiente de sua prática, podem ser identificadas várias barreiras de acesso à prática qualificada e que devem ser removidas. Para o autor, um meio ambiente qualificado deve compreender: uma estrutura de apoio regulador, suporte policial, infra-estrutura funcional, sistemas eficientes e eficazes de comunicação, referência e transporte, equipamentos e suprimentos adequados.

O reconhecimento de que alguém recebeu um treinamento não indica que está necessariamente qualificado, “treinado” implica, mas não garante a aquisição de conhecimentos e habilidades, enquanto “qualificado" implica no competente uso do conhecimento, na habilidade de prover cuidado obstétrico competente durante a gravidez, parto e pós-parto (STARRS, 1998).

Um profissional competente, segundo Jessop (1991, apud WORTH-BUTLER; MURPHY; FRASER, 1994) é aquele que possui um repertório de habilidades, conhecimentos e compreensão do que ele pode aplicar em uma variedade de contextos e organizações. A competência envolve o domínio das exigências para um funcionamento eficaz, em circunstâncias variáveis do mundo real, em uma variação de contexto e organizações.

Perrenoud (2001, p.21) conceitua competência como: 
A capacidade de um sujeito de mobilizar o todo ou parte de seus recursos cognitivos e afetivos para enfrentar uma família de situações complexas. Isso exige a conceituação precisa desses recursos, das relações que devem ser estabelecidas entre eles e da natureza do "saber mobilizar". Pensar em termos de competência é pensar a sinergia, a orquestração de recursos cognitivos e afetivos diversos para enfrentar um conjunto de situações que apresentam analogias de estrutura.

Ser competente em uma determinada profissão não implica apenas possuir um vasto e numeroso conhecimento. É saber utilizar, integrar ou mobilizar esses conhecimentos diante de uma situação real de ação (PERRENOUD, 2001). As competências requerem a produção de habilidades, um “saber fazer” necessário ao exercício profissional (LOPES, 2001).

Perrenoud (2000) afirma que competências não são saberes, nem apenas um saber-fazer ou atitude, elas mobilizam, integram e orquestram esses recursos. As competências profissionais se constroem em formação, e no caminhar de uma situação de trabalho à outra.

Para Worth-Butler, Murphy e Fraser (1994), competência pode ser vista como a capacidade de realizar uma atividade com resultados desejáveis sobre circunstâncias variadas do mundo real. Profissionais competentes são pessoas que têm aprendido um grupo adequado de habilidades e conhecimentos para fazer seu trabalho satisfatoriamente. Um profissional qualificado é então alguém que é capaz de abranger um repertório de habilidades e conhecimentos em diferentes formas e em diferentes contextos para realizar uma forma que é reconhecida como competente.

No documento publicado pela Confederação Internacional das Parteiras (ICM) sobre as Competências Essenciais para o Exercício Básico da Obstetrícia, são preconizados quais os conhecimentos e as habilidades que o profissional qualificado deve possuir para proporcionar à mulher, em todas as fases do ciclo reprodutivo, uma atenção de qualidade. As Competências Essenciais procuram responder à questão: O que uma parteira faz? E o que ela 
faz é baseado em evidência.

Este documento enumera seis amplas competências que o profissional deve possuir:

Competência 1: as parteiras têm conhecimento e habilidades requeridas das ciências sociais, saúde pública e ética que constituem a base do cuidado de alta qualidade, culturalmente pertinente, apropriado para as mulheres, recémnascido e famílias, no período reprodutivo.

Competência 2: as parteiras fornecem educação para saúde de alta qualidade e culturalmente sensível, proporcionam serviços para toda a comunidade para promover uma vida familiar saudável, gestações planejadas e uma maternidade/paternidade positivas.

Competência 3: as parteiras proporcionam cuidado pré-natal de alta qualidade, preocupadas em otimizar a saúde da mulher durante a gravidez, e isso inclui a detecção precoce, tratamento ou encaminhamento de algumas complicações.

Competência 4: as parteiras proporcionam, durante o parto, cuidado de alta qualidade, culturalmente sensível. Conduzem parto higiênico e seguro e manejam situações de emergência para otimizar a saúde das mulheres e dos recém-nascidos.

Competência 5: as parteiras oferecem à mulher cuidado integral, de alta qualidade, culturalmente sensível, durante o pós-parto. 
$>$ Competência 6: as parteiras proporcionam cuidado integral de alta qualidade para o recém-nascido saudável, do nascimento até dois meses de idade (INTERNATIONAL CONFEDERATION OF MIDWIVES, 2002).

Cada um desses seis enunciados traz uma lista de conhecimentos e habilidades básicas requeridos para uma prática segura em qualquer situação, eles determinam também os conhecimentos e as habilidades adicionais que podem ser adotados ou não de acordo com a realidade de cada país (ANEXO A).

As competências essenciais podem servir como base para formação curricular, como diretrizes para o desenvolvimento de políticas de regulação, como também de referência para a atuação prática dos profissionais e suas associações (FURLLERTON et al., 2003).

A preocupação com a qualidade da formação, assim como com a prática desenvolvida pelos profissionais que atendem ao parto e nascimento, vem de longa data. Na década de 1970, a Faculdade Americana de Enfermeira-parteira (ACNM), instituição fundada em 1955, que tem buscado continuamente melhorar a prática e a educação em obstetrícia, publicou o primeiro documento, em 1978, sobre competências essenciais para prática da obstetrícia básica (AVERY, 2000).

Vários estudos têm sido realizados nos países em desenvolvimento com o objetivo de avaliar as competências do pessoal qualificado para o nascimento. Num estudo realizado em quatro países (Benin, Equador, Jamaica e Ruanda), os pesquisadores encontraram que em média os provedores responderam corretamente a 55,8\% das questões de conhecimento, e realizaram 48,2\% dos passos de habilidades corretamente. Os profissionais avaliados foram médicos especialistas, médicos residentes, parteiras profissionais, enfermeiras e acadêmicos de medicina, divergindo em número e categorias entre os países (HARVEY et al., 2004).

Muitos dos participantes daquele estudo demonstraram competência inadequada 
até mesmo em procedimentos para salvar vidas e prevenções básicas. Por exemplo, a maioria dos participantes não identificou corretamente os três elementos que constituem o tratamento ativo do terceiro período do parto (dequitação da placenta): aplicação rápida de ocitocina após o parto, cortar imediatamente e clampar o cordão umbilical e tracionar o cordão. Eles também não conseguiram responder corretamente às questões ou realizar adequadamente procedimentos básicos para controlar hemorragia pós-parto, primeira causa de morte materna no mundo. Muitos não conseguiram descrever ou demonstrar uma boa técnica de assepsia, até mesmo com todos os equipamentos necessários em mãos.

O partograma é uma ferramenta básica e de baixo custo para o acompanhamento do parto e diagnóstico apropriado de complicações. Foram encontrados no estudo escores baixos na realização do partograma, aumentando a preocupação de que os provedores não eram capazes de reconhecer o início de uma complicação de uma maneira rápida.

Os autores sugerem que a comunidade internacional deve promover com mais eficiência a adoção das diretrizes do Manejo Integrado da Gravidez e Nascimento (IMPAC), publicado pela OMS que abordam normas e padrões de atenção obstétrica baseados em evidências científicas. Sugerem também que seja rotineiramente adotado o treinamento préserviço e/ou em serviço dos padrões de atenção baseados em evidências, como o IMPAC, para que assim, em longo prazo, se consiga desenvolver verdadeiramente nos profissionais de saúde o que a OMS define como “pessoal qualificado” (HARVEY et al., 2004).

Fako, Forcheh e Ncube (2004) enfatizam, com base nos achados de uma pesquisa realizada em Botsuana, a importância de um profissional qualificado, que tenha recebido treinamento obstétrico, na identificação de sinais de risco na mulher grávida, no tratamento subseqüente das complicações e na redução da taxa de mortalidade materna, contribuindo assim verdadeiramente para uma maternidade sem risco. Os autores encontraram que as enfermeiras, especialistas em obstetrícia, que trabalham em instituições equipadas 
adequadamente, que freqüentam seminários e workshops, e que consultam suas colegas quando enfrentam dúvidas, possuem maior conhecimento profissional, habilidades e atitudes, portanto, são mais competentes na realização dos cuidados maternos de saúde. Eles encontraram também que a experiência profissional e o treinamento em serviço contribuem para aumentar a competência e a confiança desta profissional.

Conhecer a qualificação do pessoal responsável pelo atendimento ao parto bem como as competências desenvolvidas por eles é uma forma de estudar um importante indicador de referência nacional para monitorar o progresso em direção ao alcance da morbimortalidade materna e da neonatal.

Esta pesquisa propõe o estudo da realidade do município de Rio Branco (AC), na esperança de contribuir com as políticas nacionais para a redução das mortes materna e neonatal e realização de cesáreas desnecessárias.

\subsection{Pressuposto e questões da pesquisa}

Para o alcance da maternidade segura, as evidências científicas mostram que a atenção qualificada ao parto é elemento fundamental na redução das mortes maternas e neonatais, os profissionais de saúde devem possuir competências essenciais para resolução de problemas, pensamento crítico e tomada de decisões. Eles devem ser capazes de manejar o trabalho de parto e o parto normal, reconhecer o início das complicações, realizar intervenções essenciais, dar início ao tratamento e supervisionar o encaminhamento da mulher, quando não é possível realizar a intervenção naquele contexto. Diante destas exigências, trazemos como pressuposto que existem diferentes profissionais que atuam diretamente no atendimento do trabalho de parto e parto, nas maternidades do município de Rio Branco-AC, e que as ações e habilidades profissionais revelam construções de 
competências distintas entre os profissionais de enfermagem.

Com base neste pressuposto, emergiram as seguintes questões norteadoras:

1- Quem são os profissionais que atuam na assistência ao parto, nas maternidades de Rio Branco?

2- As competências essenciais em obstetrícia são desenvolvidas pelos profissionais de enfermagem na condução do trabalho de parto e parto?

3- O desenvolvimento das competências essenciais compete à qual categoria profissional? 
Objetivos

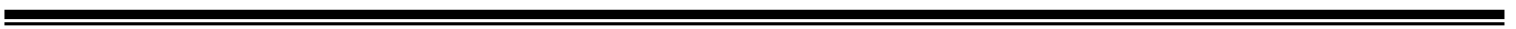




\section{OBJETIVOS}

\subsection{Objetivo geral}

Conhecer a realidade do atendimento ao trabalho de parto e parto, nas maternidades do município de Rio Branco-AC, com especial enfoque no pessoal de enfermagem.

\subsection{Objetivos específicos}

Identificar os profissionais que atuam na atenção ao parto;

Descrever o perfil dos profissionais de enfermagem que atuam na atenção ao trabalho de parto e parto normal;

Analisar as competências essenciais desenvolvidas na prática, pelos profissionais de enfermagem que atuam na atenção ao trabalho de parto e parto normal. 
Metodologia 


\section{METODOLOGIA}

\subsection{Tipo de estudo}

A opção metodológica deste estudo decorreu das características do objeto e dos objetivos pretendidos, os quais requerem um estudo descritivo com abordagem quantitativa.

Para Polit, Beck e Hungler (2004, p. 177), “a finalidade do estudo descritivo é observar, descrever e documentar os aspectos da situação”. Triviños (1987) ressalta que o foco essencial do estudo descritivo é a intenção de se conhecer uma determinada realidade, ele descreve “com exatidão” os fatos e fenômenos desta realidade.

As abordagens quantitativas e qualitativas diferem não só pela sistemática pertinente a cada uma delas, mas sobretudo pela forma de abordagem do problema em estudo. A escolha do tipo de abordagem deve estar apropriada ao tipo de estudo que se deseja realizar, sendo que a natureza do problema e o seu nível de aprofundamento é que determinam esta escolha (RICHARDSON et al., 1999). A abordagem quantitativa atua em níveis da realidade, onde os dados se apresentam aos sentidos, tem como campo de práticas e objetivos trazer à luz dados, indicadores e tendências observáveis. Deve ser utilizada “para abarcar, do ponto de

vista social, grandes aglomerados de dados, classificando-os e tornando-os inteligíveis através de variáveis” (MINAYO; SANCHES, 1993, p. 247).

Este estudo está inserido em um amplo projeto sobre o "Perfil dos Serviços de Obstetrícia nas Américas”, organizado pela OMS/OPAS, que tem o propósito de fazer um diagnóstico destes serviços e assim poder oferecer apoio e promover ações que auxiliem na melhoria da qualidade da assistência dos serviços de obstetrícia da região, promovendo uma maternidade sem risco em toda a América Latina e no Caribe.

Os parceiros na realização deste mapeamento são: a Universidade das Índias 
Ocidentais, a Associação de Faculdades e Escolas de Enfermagem na América Latina, a Confederação Internacional das Parteiras (Regional), e os Centros Colaboradores da OMS para a Enfermagem e Obstetrícia. No Brasil, o coordenador desta pesquisa sobre o mapeamento dos serviços de obstetrícia é o Centro Colaborador da Organização Mundial de Saúde para o desenvolvimento da pesquisa em enfermagem da Escola de Enfermagem de Ribeirão Preto da Universidade de São Paulo (EERP-USP) (OPAS, 2004).

\subsection{Local do estudo}

\subsubsection{O Estado do Acre}

O Estado do Acre está localizado no extremo sudoeste da Amazônia brasileira, ocupando 3,2\% de sua área. Faz fronteira com o Departamento de Pando (Bolívia), Madre de Diós (Peru) e com os Estados do Amazonas e de Rondônia (Brasil) (ACRE. GOVERNO DO ESTADO DO ACRE, 2002). Possui uma população de 557.526 habitantes, da qual 66,41\% residem na área urbana (INSTITUTO BRASILEIRO DE GEOGRAFIA E ESTATÍSTICA. IBGE, 2000).

A população indígena é de 10.673 habitantes (1,73\%), a população ribeirinha é de 82.503 habitantes (13,43\%). A população acreana na faixa etária entre 10 e 59 anos em 2004 era de 417.513 habitantes, $68 \%$ da população do Estado. O crescimento populacional no Estado entre 1999 e 2003 foi de 113,76\%, apresentando um maior incremento na faixa etária de 80 anos e mais (137,53\%), significando maior expectativa de vida da população (ACRE. GOVERNO DO ESTADO DO ACRE, 2004). Em 2004, a expectativa de vida ao nascer era de 66,2 anos para os homens e 72,2 anos para as mulheres (IBGE, 2005).

O Produto Interno Bruto (PIB), em 2001, foi R\$ 1.921.000.000,00 (Um bilhão, 
novecentos e vinte e um milhões de reais) e o PIB per capita foi R\$ 3.351,00 (Três mil, trezentos e cinqüenta e um reais), que representa 3,36\% do PIB da região Norte e $0,16 \%$ do PIB nacional. A população economicamente ativa, no período, era de 191.311 habitantes, representando 33,30\% da população. Em 2003, a população economicamente ativa passou para 24,51\% e a razão de dependência é de 75,49\%. As principais atividades econômicas do Estado são: indústria de transformação (borracha, madeira); agropecuária; construção civil; comércio de objetos pessoais e de uso doméstico; atividades imobiliárias, aluguéis e serviços prestados às empresas (ACRE. GOVERNO DO ESTADO DO ACRE, 2004).

Quanto à educação, a taxa de alfabetização para a população de 10 anos ou mais de idade, de acordo com o Censo Demográfico de 2000, é de 76,9\% (IBGE, 2000). A rede de ensino é composta por 1.643 estabelecimentos de ensino, sendo 725 estaduais, 917 municipais e um federal. Dos 725 estabelecimentos estaduais, 185 estão localizados na zona urbana e 540 na zona rural. Quanto aos 917 estabelecimentos municipais, 126 estão localizados na área urbana e 791 na área rural. O único estabelecimento federal está localizado em área urbana. A rede privada de ensino é composta por 44 estabelecimentos, todos localizados em área urbana. Em 2003, a rede de ensino no Estado registrou 258.909 matrículas, das quais 94,5\% foram efetuadas na rede pública estadual e municipal, 0,2\% em escola federal e 5,3\% na rede privada de ensino (ACRE. GOVERNO DO ESTADO DO ACRE, 2004).

A taxa de analfabetismo das pessoas com 15 anos ou mais de idade, segundo dados da Pesquisa Nacional por Amostra de Domicílios (PNAD) de 2004, é de 16,9\%, enquanto a taxa de analfabetismo funcional das pessoas com 15 anos ou mais de idade no Acre é de 30,8\% (33,5\% para os homens e 28,4\% para as mulheres). A taxa de analfabetismo funcional encontra-se em patamar superior à média da região Norte $(23,8 \%)$ e do Brasil (24,8\%), no mesmo período (IBGE, 2005).

A taxa de escolarização entre pessoas de 7 a 14 anos é de 95,5\%, e entre pessoas 
de 15 a 17 anos é de 80,8\%. Na faixa etária entre 18 e 24 anos, a taxa cai para 40,3\%, sendo que no Brasil esta taxa é de 33,9\%. Vale ressaltar que as taxas de escolarização do Estado do Acre incluem apenas a população da área urbana (IBGE, 2003).

A rede de saneamento básico e coleta de resíduos é muito precária no Estado. Dos domicílios existentes, em 2004, na zona urbana, 41,7\% eram providos de água canalizada da rede geral, $17,6 \%$ possuíam água canalizada de poço ou nascente na propriedade, 37\% possuíam água no domicílio sem canalização interna, sendo 21,2\% da rede geral e 15,8\% de poço ou nascente. Quanto ao tipo de esgotamento sanitário, 20,7\% possuíam rede coletora, 37,8\%, fossa séptica, 14,4\%, fossa rudimentar e 27,1\% dos domicílios não possuíam banheiro. O lixo produzido era coletado diariamente em $77,1 \%$ dos domicílios, em $8,8 \%$ o lixo era coletado indiretamente, e em 6,7\% era queimado ou enterrado na própria propriedade (IBGE, 2005).

Em 2004, o Estado apresentou uma taxa de fecundidade total de 3,0, maior do que a média no Brasil que é de 2,3, e também uma taxa bruta de natalidade de 27,9\%, enquanto no Brasil esta taxa é de 20,9\%, as regiões Norte e Nordeste do país possuem as maiores taxas desses indicadores. A taxa bruta de mortalidade no Estado é de 5,9\%, não diferindo muito do Brasil que é de 6,3\% (IBGE, 2005).

A razão da mortalidade materna no Estado tem variado nos últimos anos. Em 1999, a razão foi de 40,10, em 2000 foi de 58,74, em 2001 foi de 20,6, em 2002 foi de 37,94, e em 2003 a razão da mortalidade materna foi de 51,97 por 100.000 nascidos vivos. No que se refere às causas de mortes em mulheres em idade fértil, aquela relacionada à gravidez/parto/puerpério ocupou o sétimo lugar no Estado, no ano de 2003 (ACRE. GOVERNO DO ESTADO DO ACRE, 2004).

A proporção de óbitos neonatais no total de óbitos de menores de 1 ano no Estado, em 2003, não difere muito do restante do país. No Acre, o total de óbitos neonatais é de 
$58,2 \%$, destes $46,5 \%$ são óbitos neonatais precoces (de 0 a 6 dias). No Brasil, o total de óbitos neonatais é de $64,6 \%$, e os óbitos neonatais precoces correspondem a 48,9\% destes. A proporção de nascidos vivos oriundos de mães adolescentes com idade entre 15 e 19 anos, em 2003, foi de 25,4\% no Estado. No Brasil, este índice é de 20\%, as regiões Norte e Nordeste novamente são responsáveis pelas maiores taxas juntamente com o Centro-Oeste (IBGE, 2005). No período de 1999 a 2003, os partos de mães adolescentes com idade entre 15 e 19 anos representavam 28,95\% do total dos partos do Estado do Acre no período (ACRE. GOVERNO DO ESTADO DO ACRE, 2004).

A cobertura de pré-natal de mulheres com quatro ou mais consultas no Estado é de 32,3\%, e a cobertura de exames citopatológicos na população feminina de 25 a 59 anos foi de 15,7\% (ACRE. GOVERNO DO ESTADO DO ACRE, 2004).

\subsubsection{Rio Branco}

A capital do Estado do Acre, Rio Branco, é o maior centro populacional, comercial, cultural e industrial do Estado. O município localiza-se na região leste do Estado, possui 286.082 habitantes. Rio Branco concentra 51,31\% do total da população do Estado, sendo que 89,42\% da população encontra-se na zona urbana (IBGE, 2002; SEIAM, 2002).

Na área da saúde, conta com 915 leitos hospitalares, sendo 765 disponíveis ao SUS. A taxa bruta de natalidade do município é de 25,7\%, A taxa bruta de mortalidade é de 5,3\%. A razão da mortalidade materna, em 2003, foi de 27,68 por 100.000 nascidos vivos (IBGE, 2002; SISPACTO, 2005).

Em Rio Branco, existem uma maternidade pública e dois hospitais que atendem a mulher no processo do parto e nascimento. Estes hospitais atendem tanto as clientes do SUS, como as clientes de convênio de saúde e particulares. 
A maternidade pertence à rede estadual de saúde, do município de Rio Branco. Foi fundada em 1950, possui 84 leitos, sendo todos reservados à clientela do SUS. Esta instituição, juntamente com o Hospital da Criança, constitui o Sistema de Assistência à Saúde da Mulher e da Criança (SASMC). A maternidade é referência no Estado para o atendimento à mulher.

Em 2000, recebeu o prêmio Galba de Araújo, oferecido pelo Ministério da Saúde às instituições que adotam um atendimento humanizado às mulheres e aos seus filhos. Em 2001, recebeu o título de Hospital Amigo da Criança, pelo serviço de apoio, promoção e incentivo ao aleitamento materno oferecido em todos os momentos da assistência à mulher e ao seu filho.

Os dois hospitais gerais possuem uma ala de maternidade. O primeiro deles foi fundado em 1928, possui duas salas de parto, um pré-parto com 5 leitos e uma ala de alojamento conjunto com 13 leitos, no entanto, esta maternidade encontra-se fechada há 2 anos por problemas administrativos. O outro hospital é uma instituição filantrópica, fundada em 1969, possui 32 leitos na ala da maternidade, atende apenas as gestantes consideradas de baixo risco.

Portanto, atualmente apenas duas instituições atendem a mulher no processo de parto e nascimento na cidade de Rio Branco. A presente pesquisa foi realizada nestas duas instituições.

\subsection{Sujeitos da pesquisa}

Os participantes deste estudo foram todos os profissionais de enfermagem que atendem a mulher no trabalho de parto e parto no hospital filantrópico (maternidade “seringueira”) e na maternidade pública (maternidade “castanheira”) de Rio Branco. 
Os sujeitos deste estudo foram: enfermeiras, técnicos em enfermagem e auxiliares de enfermagem que estavam trabalhando na assistência ao parto, no momento da realização da coleta de dados, e concordaram em participar do estudo.

\subsection{Aspectos éticos}

Em atenção à Resolução $n^{\circ}$ 196/96 do Conselho Nacional de Saúde, referente a pesquisas envolvendo seres humanos, os sujeitos deste estudo só participaram dele após a assinatura do Termo de Consentimento Livre e Esclarecido. Quando os profissionais de enfermagem assinaram este termo, eles concordaram em participar da pesquisa esclarecidos da garantia do seu anonimato, do sigilo das informações prestadas e da segurança de que estas informações somente seriam utilizadas para fins de pesquisa (APÊNDICE A).

O trabalho de campo foi iniciado após a aprovação do projeto de pesquisa pelo Comitê de Ética em Pesquisa da Escola de Enfermagem de Ribeirão Preto, em observância às diretrizes e normas que regulamentam as pesquisas envolvendo seres humanos, descritas na Resolução nº 196/96 (ANEXO B).

\subsection{Coleta de dados}

Para caracterizar as instituições que prestam assistência ao parto no município de Rio Branco, foi realizada uma busca de informações junto aos setores administrativos das mesmas sobre o número de leitos, número de procedimentos gerais e obstétricos, número de partos, número de profissionais que atuam na assistência ao parto e sua formação, serviços disponíveis para a assistência à mulher, normas de funcionamento da instituição, tais como, regime de trabalho, normas para alta, para visitas, rotinas no atendimento ao puerpério e no 
atendimento ao recém-nascido.

A coleta de dados ocorreu de duas formas. A primeira foi através de entrevista estruturada com todos os sujeitos do estudo onde obtivemos informações sociodemográficas e identificamos as funções e atividades exercidas por eles no atendimento à mulher no processo do parto e nascimento. O roteiro de entrevista, instrumento utilizado nesta técnica, constou de perguntas abertas e fechadas e foi aplicado em contato direto, pela própria pesquisadora (APÊNDICE B). A entrevista foi realizada no próprio local de trabalho do profissional, com duração em média de 15 minutos.

A segunda forma de coleta dos dados foi a observação não participante e estruturada do contexto de atendimento à parturiente e puérpera. Segundo Richardson et al. (1999), na observação não participante, o pesquisador atua apenas como espectador, atento aos acontecimentos pertinentes àquilo que se está investigando. Com base nos objetivos da pesquisa, e por meio de um roteiro de observação, ele procura ver e registrar o máximo de ocorrências que interessa ao seu trabalho.

De acordo com Berk (1986) apud Hager, Gonczi e Athanasou (1994), o processo de obtenção de dados por observação sistemática é uma estratégia fundamental na avaliação de desempenho para tomar decisões sobre um indivíduo. Embora na presente pesquisa não estivéssemos interessados no desempenho do próprio indivíduo ou profissional, mas nos interessava saber como as competências essenciais no atendimento à parturiente estavam sendo desenvolvidas no contexto estudado, então optamos por realizar a observação direta do atendimento das parturientes nos setores onde ela recebe atendimento: setor de internação, enfermaria de pré-parto, sala de parto e no pós-parto ( $4^{\circ}$ período).

Como lembram Hager, Gonczi e Athanasou (1994), quando se pretende avaliar competências, significa decidir que aspectos dos padrões de competências devem ser avaliados. Para este estudo, para a avaliação das competências essenciais desenvolvidas no 
atendimento a parturientes em trabalho de parto e parto, foi elaborado o roteiro de observação tomando como base os seguintes documentos: a) competências essenciais para o exercício básico da obstetrícia (ICM), b) guia prático da assistência ao parto normal da OMS, e c) instrumento do projeto sobre o "Perfil dos Serviços de Obstetrícia nas Américas” organizado pela OMS/OPAS. Este roteiro de observação foi direcionado para as habilidades que os profissionais desenvolvem no cotidiano e foi estruturado na forma de check-list (APÊNDICE C). Realizamos um estudo-piloto com o roteiro de observação para as devidas correções. Em atenção aos preceitos éticos, foi solicitado às parturientes o consentimento livre e esclarecido para a realização da observação (APÊNDICE D).

Como a finalidade da observação era aproximar o máximo possível da realidade do atendimento dos profissionais de enfermagem, esta foi realizada em todos os turnos de trabalho em cada instituição pesquisada, para assim podermos observar todas as equipes que prestam assistência à mulher. Para tanto, a observação foi realizada em turno de 6 horas contínuas, no período da manhã, da tarde e da noite. No período da manhã, foi realizada das 07 às 13 horas, da tarde das 13 às 19 horas e no período noturno o horário foi das 19 horas à 01 hora da manhã. Foi realizado um total de 36 turnos de 6 horas de observação, dezoito turnos em cada instituição.

Outro critério foi observar os quatro momentos das parturientes (admissão, trabalho de parto, parto e pós-parto) em todos os turnos. Foi possível observar 14 admissões, 34 trabalhos de parto, 17 partos e 17 pós-partos. Dos 17 partos que observamos, 11 foram partos normais realizados pela equipe de enfermagem, seis foram partos normais realizados por médicos.

Nos partos normais realizados pelos médicos, observamos as atividades desenvolvidas pela equipe de enfermagem, já que as ações desenvolvidas pelo profissional médico não era o foco do nosso estudo. 
A definição das parturientes que seriam observadas durante o trabalho de parto foi por sorteio entre as mulheres que se encontravam internadas no pré-parto. A observação ocorreu durante seis horas para 16 das 34 parturientes. Para 11 parturientes, a observação foi em torno de quatro horas, já para sete parturientes esta observação aconteceu apenas por duas horas. Esta redução do tempo de observação aconteceu devido ao desfecho do parto.

\subsection{Análise dos dados}

Os dados coletados numa investigação não respondem sozinhos às questões de pesquisa, eles necessitam ser sistematicamente analisados, de forma que as tendências e os padrões de relacionamentos possam ser identificados (POLIT; BECK; HUNGLER, 2004).

A análise estatística foi realizada por meio de tabelas de contingências e o teste exato de Fisher. A estatística descritiva foi utilizada para descrever e sintetizar os dados. Os dados foram analisados com base nos documentos que subsidiam a atenção qualificada ao parto. São eles: as competências essenciais publicadas pelo ICM/OMS/OPAS, guia prático da assistência ao parto normal (OMS), as diretrizes do Manejo Integrado da Gravidez e Nascimento (IMPAC), publicado pela OMS e pelo manual Parto, aborto e puerpério Assistência humanizada à mulher, do Ministério da Saúde. 
Resultados 


\section{RESULTADOS}

\subsection{Caracterização das instituições}

\subsubsection{Maternidade "seringueira"}

Esta instituição possui 158 leitos e 41 apartamentos. São 48 leitos cirúrgicos, 52 leitos clínicos (20 leitos para clientes do sexo feminino e 32 para o sexo masculino), 32 leitos obstétricos, 07 leitos de UTI, 10 leitos no berçário (06 incubadoras e 04 berços aquecidos) e 09 leitos no pré-parto.

Atualmente possui 304 funcionários, sendo 169 profissionais de enfermagem (24 enfermeiras, 62 técnicos em enfermagem e 83 auxiliares de enfermagem). Possui também uma nutricionista e uma assistente social. Existem 236 médicos credenciados no hospital, destes 35 são obstetras.

Em 2004, foram realizados nesta instituição 5.305 procedimentos obstétricos, 3.206 procedimentos cirúrgicos e 3.271 procedimentos clínicos. Nesse ano, ocorreram 10 óbitos de recém-nascidos, 09 natimortos, 80 óbitos de adulto, sendo 01 destes óbitos de um puérpera, declarado como morte materna.

Os profissionais de enfermagem trabalham em regime de 36 horas semanais, com turno de 06 horas no plantão diurno e 12 horas no noturno. Alguns profissionais trabalham em plantões extras, para cobrir folgas. O número de plantões extras por mês é variado.

No centro obstétrico, existem duas salas de parto, um pré-parto amplo com 09 leitos e uma mesa de exame que é separada dos leitos por uma divisória. Esta mesa é utilizada para examinar as parturientes que estão internadas e também para realizar o exame de admissão das clientes que procuram o hospital para saberem se estão em trabalho de parto e 
irão ficar internadas. Ao lado da mesa existe um aparelho de sonar. Existe também no préparto um banheiro com um boxe de chuveiro e três de vasos sanitários, com uma ampla pia. Para cada leito do pré-parto, existem uma cadeira plástica e uma mesa de cabeceira. O centro obstétrico possui ar condicionado central. As salas de parto são equipadas com uma mesa cirúrgica, uma escadinha, um suporte de soro, uma mesa de mayo, uma mesa auxiliar, um foco central, um aparelho de sonar, um armário com medicação e materiais, dois bancos, um hâmper, um recipiente de lixo giratório, um recipiente para receber a placenta, possui também oxigênio, aspirador e ar comprimido canalizados. Entre as duas salas de parto, existe uma pequena sala de recepção ao recém-nascido, onde existe um berço aquecido, material de intubação, caixa com algumas medicações de emergência. O recém-nascido é atendido nesta sala apenas em caso de emergência, a rotina para o atendimento é realizada no berçário. No corredor entre as salas de parto, existe uma pia com três torneiras para escovação das mãos.

Trabalham no centro obstétrico 02 enfermeiras, 04 técnicas em enfermagem e 06 auxiliares de enfermagem. Existem também 09 obstetras que realizam plantão de 24 horas no centro obstétrico.

As enfermeiras realizam o gerenciamento e supervisão das atividades do centro obstétrico, do alojamento conjunto e do berçário. As técnicas e auxiliares de enfermagem são responsáveis pelo acompanhamento do trabalho de parto e pela realização do parto. Elas são conhecidas pelos outros profissionais da instituição, pelas parturientes, e pela comunidade como parteiras.

Nos turnos diurnos, manhã e tarde, encontram-se de plantão no centro obstétrico uma enfermeira, duas técnicas ou auxiliares de enfermagem e um obstetra. No plantão noturno, não existe uma enfermeira designada para o centro obstétrico, existem apenas duas enfermeiras em todo o hospital, sem considerar a enfermeira que fica na unidade de tratamento intensivo. Portanto, os profissionais que prestam assistência às mulheres neste 
horário são duas técnicas ou auxiliares de enfermagem e um obstetra.

O centro obstétrico está localizado em uma ala nova do hospital que foi inaugurada em março de 2000. Nesta ala encontram-se também o berçário, o alojamento conjunto, o centro cirúrgico, a central de material esterilizado e o repouso do médico obstetra. O centro cirúrgico possui 05 salas de cirurgia, a primeira delas é sempre reservada para a cesárea. Até a inauguração desta nova ala, os obstetras não permaneciam na instituição quando estavam de plantão. Era adotado o plantão a distância, o médico passava visita, no início do plantão, e depois era chamado pelas parteiras quando necessário.

O número de partos realizados nesta instituição em 2004 foi de 5.470, destes, 3.608 foram normais e 1.862 foram cesáreas, evidenciando uma porcentagem de cesáreas de 34\% do total dos partos. De janeiro a junho de 2005, foram realizados 2.590 partos, 1.475 normais e 1.115 cesáreas, a porcentagem de cesáreas neste período atingiu 43\% dos partos.

Nesta instituição não é permitida a entrada de acompanhantes. Quando a mulher procura a maternidade para ser examinada, o acompanhante e seus pertences ficam na recepção. Um funcionário acompanha a mesma até o pré-parto. O profissional examina a mulher e, se ela estiver em trabalho de parto, é orientada a retornar à recepção para fazer seu prontuário, falar com a família e pegar seus pertences. Ela retorna sozinha para a recepção, e um funcionário a acompanha até o pré-parto com o prontuário em mãos. Se no momento do exame for diagnosticado trabalho de parto muito avançado, a parturiente fica no pré-parto, o funcionário da recepção é quem faz seu prontuário e traz os pertences dela. A partir deste momento ela receberá a visita da família, enquanto estiver internada apenas no horário de visitas do hospital que acontece diariamente das 14 h30 às 15 h. Neste horário as parturientes recebem suas visitas no hall em frente ao pré-parto, cada uma leva sua cadeira plástica do préparto.

Após o parto, a puérpera é encaminhada ao alojamento conjunto e permanece sob 
os cuidados diários da equipe de enfermagem. Recebe alta com 24 horas, se for parto normal, e com 72 horas, se for parto cesárea. Às vezes as puérperas de parto normal saem entre 12 e 24 horas.

Os recém-nascidos (RN) são levados ao berçário logo após o nascimento. Uma funcionária do berçário é chamada, quando o parto acontece. Ela faz a identificação do RN e leva-o para o berçário. Ele recebe banho em água corrente, instilação de nitrato de prata a 1\% nos olhos e vitamina $\mathrm{K}$ intramuscular. A aspiração das vias aéreas superiores é realizada somente quando necessário. Após receberem os primeiros cuidados, são levados ao alojamento conjunto 2 a 3 horas, após o parto, no caso de normal, e 6 a 8 horas quando o parto for cesárea. Diariamente pela manhã, uma funcionária do berçário vai ao alojamento conjunto dar o banho no recém-nascido. Este banho acontece nas enfermarias ao lado do leito materno no próprio berço. Neste momento são realizadas orientações às mães sobre como realizar o banho, e como cuidar do coto umbilical. É realizado curativo com álcool a 70\%. A declaração de nascidos vivos é preenchida pela parteira, na sala de parto.

Ao lado do berçário existe a sala de vacinas. Todos os recém-nascidos, exceto os prematuros e de baixo peso, são vacinados contra a hepatite B e a BCG. Nos domingos e feriados, a vacinação não acontece. No momento da alta, as mães são orientadas a procurarem um centro de saúde mais próximo de sua residência, para realizar a vacina e o teste do pezinho nos recém-nascidos, e também são orientadas quanto à prescrição médica, se houver.

\subsubsection{Maternidade "castanheira”}

A instituição possui duas alas de unidade de internação, uma unidade de cuidados intensivos e cuidados intermediários ao recém-nascido, um banco de leite humano, um centro obstétrico e um ambulatório onde funciona o atendimento pré-natal de gestantes de alto risco 
encaminhadas das unidades de saúde e de outros municípios, e o Grupo de Estímulo ao Aleitamento Materno (GEAMA) que acompanha a mulher e seu recém-nascido até seis meses de vida, apoiando e incentivando a amamentação exclusiva.

Esta maternidade está interligada ao hospital da criança, formando um sistema de assistência, com algumas estruturas comuns. O sistema possui em conjunto um laboratório, uma unidade transfusional, uma cozinha, uma lavanderia e uma unidade radiológica.

O quadro de pessoal é composto de 344 funcionários. A enfermagem conta com 144 profissionais, 31 enfermeiras, sendo 22 delas enfermeiras obstétricas, 107 auxiliares de enfermagem e apenas 06 profissionais são contratados como técnico em enfermagem, apesar de 48 auxiliares já terem concluído o curso de técnico em enfermagem.

Na sala de parto, trabalham 06 enfermeiras obstétricas, 05 técnicos em enfermagem e 07 auxiliares de enfermagem. Nos plantões diurnos, a equipe que atende a mulher no processo de trabalho de parto e parto são duas enfermeiras obstétricas, quatro auxiliares ou técnicas de enfermagem e quatro médicos, no plantão noturno, esta equipe conta com apenas uma enfermeira.

A maternidade conta com 20 médicos obstetras, três médicos residentes em obstetrícia, nove pediatras, sendo um deles neonatologista, seis médicos anestesistas, dois médicos clínicos gerais, e um médico para realizar exames de ultra-sonografia. A instituição possui também em seu quadro seis fisioterapeutas, duas assistentes sociais, três psicólogas, uma fonoaudióloga e uma bióloga. Os médicos trabalham em regime de 12 horas, as enfermeiras trabalham 6 horas durante a semana, no período diurno, e 12 horas no final de semana e período noturno. Os técnicos e auxiliares de enfermagem trabalham em regime de 12 horas.

Atualmente a instituição possui 69 leitos, sendo oito deles destinados às gestantes patológicas, os demais são designados às puérperas, às pacientes que realizaram curetagem 
após aborto e eventualmente às pacientes com câncer ginecológico, quando não há leito disponível na Fundação Hospitalar do Acre. Todos os 69 leitos localizam-se numa única ala da instituição. Numa outra ala, encontram-se 15 leitos distribuídos em três enfermarias, denominadas “aguarda RN”, “mãe-canguru” e “mãe-coruja”.

A enfermaria "aguarda $R N$ ” destina-se às mães cujos recém-nascidos ( $R N)$ encontram-se na unidade de cuidados intermediários ou na unidade de cuidados intensivos, estas mães permanecem na instituição enquanto o RN não obtiver alta, elas são incentivadas a realizar a amamentação e a doar o leite excedente para o banco de leite humano da maternidade. A enfermaria "mãe-canguru” é para as mães que tiveram recém-nascidos prematuros e que podem permanecer junto as suas mães no método canguru. Já a enfermaria “mãe-coruja” destina-se às mães e recém-nascidos que aguardam algum exame, ou que ainda estejam recebendo algum tratamento, portanto não receberam alta.

Em 2004, foram realizados 2.838 partos, 1.766 partos normais e 1.072 partos cesáreas, evidenciando uma porcentagem de cesáreas de 37,8 \% do total dos partos. Estes partos resultaram em 2.771 recém-nascidos vivos e 67 natimortos. Nesse ano, ocorreram 91 óbitos de recém-nascidos e um óbito materno, e foram realizados 1.612 tratamentos clínicos. No período de janeiro a junho de 2005, ocorreram 1.060 partos normais, destes 546 foram com episiotomia, logo a taxa de episiotomia foi de 51,5 \% dos partos no período, e aconteceram 806 partos cesáreas neste período, 43,19\% do total dos partos.

O centro obstétrico desta instituição funciona também como pronto-atendimento à mulher com queixas obstétricas e ginecológicas. Sua planta física é composta por um hall de entrada com um grande balcão onde as mulheres são recepcionadas, dois consultórios, uma sala com três leitos para pacientes que sofreram abortamento e aguardam curetagem, para aquelas que apenas recebem medicação, para outros casos atendidos e para parturientes, quando necessário. Possui também um pré-parto com três leitos, neste pré-parto existe um 
banheiro que possui um vaso sanitário e um chuveiro. Duas salas de parto que funcionam também como sala de exames para as parturientes internadas, e de sala de admissão para as mulheres gestantes que procuram a maternidade com suspeita de início de trabalho de parto. Há uma sala de curetagem, uma central de material esterilizado e um centro cirúrgico em área restrita com duas salas de cirurgia. No momento da pesquisa, apenas uma sala de cirurgia encontrava-se funcionando. Os consultórios, o hall de entrada, as salas de parto, a sala de curetagem e o centro cirúrgico possuem aparelho de ar condicionado.

Nas salas de parto, há uma mesa ginecológica, um suporte de soro, uma escadinha, uma mesa auxiliar, uma mesa de mayo, dois bancos, um estante com material e medicação, um aparelho de sonar, uma pequena pia, oxigênio e ar comprimido canalizados.

As enfermeiras obstétricas são responsáveis pela supervisão e gerenciamento da assistência oferecida em todo o centro obstétrico. Elas estão presentes no atendimento das urgências, na assistência às pacientes graves, são responsáveis pela realização de procedimentos invasivos da enfermagem, como a passagem de uma sonda vesical. Acompanham o trabalho de parto e realizam o parto das parturientes em conjunto com os obstetras.

Para todas as mulheres que são atendidas na maternidade, é preenchido um boletim de atendimento. O prontuário é aberto apenas em caso de internação. As parturientes são examinadas pelo médico e encaminhadas para fazer o prontuário na recepção, que fica em frente ao centro obstétrico. Em geral não é permitida a entrada de acompanhantes, existe o horário de visita diariamente das $14 \mathrm{~h}$ às $15 \mathrm{~h}$ onde as parturientes recebem suas visitas no hall em frente ao centro obstétrico. Nos casos em que a parturiente for adolescente e a família solicitar para a assistente social o desejo de acompanhá-la, é realizada uma avaliação para verificar a possibilidade de algum familiar do sexo feminino permanecer junto da mesma.

Logo após o parto, a puérpera é encaminhada à unidade de internação, onde 
permanecerá sob os cuidados da enfermagem por 24 horas, se for parto normal, e por 72 horas, se for cesárea. Geralmente as puérperas de parto normal saem de alta entre 12 e 24 horas. O RN, tanto de parto normal como de cesárea, recebe os primeiros cuidados num boxe no corredor entre as salas de parto. Neste local existem um berço aquecido, um aspirador, oxigênio e material de intubação. Quando a parturiente é encaminhada à sala de parto, a auxiliar de enfermagem toca a campainha avisando o berçário. Uma funcionária do berçário vem até o centro obstétrico, preenche a ficha do RN com os dados da mãe, realiza os cuidados básicos, seca o RN, faz a identificação da impressão digital da mãe e plantar do RN, assim como uma pulseira no RN e, se necessário, aspira as vias aéreas superiores. Em geral esta funcionária é uma auxiliar de enfermagem, quando o parto é cesárea, quem recepciona é a médica pediatra. Nos casos de parto normal, esporadicamente é a médica quem recepciona o RN. Os demais cuidados são realizados no próprio berçário, a credeização, a administração da vitamina K e o banho em água corrente. Diariamente uma funcionária do berçário realiza o banho do RN nas enfermarias, em água corrente. Existe uma pia com chuveiro com água quente em cada enfermaria. As mães são orientadas sobre o banho e os cuidados com o coto umbilical no momento do banho do RN. É realizado um curativo no coto com álcool a 70\%. Os RNs recebem vacina contra a hepatite B e a BCG, exceto os prematuros e de baixo peso. Fica a cargo de uma funcionária que passa diariamente nas enfermeiras a responsabilidade pelo preenchimento da declaração de nascidos vivos.

As funcionárias do banco de leite humano realizam diariamente orientações sobre amamentação, observam a pega do RN, estimulam o aleitamento exclusivo e agendam um retorno para até sete dias de pós-parto no GEAMA, para que a mulher e a criança sejam acompanhadas até os seis meses de vida.

O GEAMA funciona no ambulatório da maternidade, possui uma equipe multiprofissional para atender a mulher e a criança. Esta equipe é composta por enfermeiras, 
técnicas e auxiliares de enfermagem, médica pediatra, nutricionista e psicóloga. O principal objetivo do grupo é estimular, apoiar e promover o aleitamento materno exclusivo. As crianças prematuras são acompanhadas até um ano de vida. O retorno no primeiro mês é semanal, no segundo é quinzenal e a partir do terceiro mês a criança é acompanhada mensalmente. No momento da alta do grupo, é realizada uma confraternização onde a mãe recebe um certificado parabenizando-a por ter amamentado seu filho, dando-lhe saúde, amor e carinho.

A Tabela 1 apresenta as categorias profissionais envolvidas no atendimento às parturientes, nas maternidades do município de Rio Branco.

Tabela 1. Distribuição dos profissionais de saúde das maternidades de Rio Branco (AC), segundo a maternidade. Rio Branco, 2005

\begin{tabular}{lccccc}
\hline & \multicolumn{5}{c}{ Profissionais de Saúde } \\
\cline { 2 - 6 } Maternidade & Enf. Obst. & Enfermeira & Técnica em Enf. & Auxiliar de Enf. & Médico \\
\hline "seringueira” & - & 02 & 04 & 06 & 09 \\
“castanheira” & 06 & - & 05 & 07 & 23 \\
\hline
\end{tabular}

\subsection{Caracterização da equipe de enfermagem}

A população deste estudo foi composta pela totalidade (30) dos profissionais de enfermagem que prestam atendimento a parturientes, nos serviços de saúde estudados.

Este grupo de profissionais é representado predominantemente pelo sexo feminino (29), com uma idade média de 41,8 anos, sendo que 50\% são casados ou vivem com parceria fixa e apenas dois profissionais não tiveram filhos (Tabela 2). A idade dos filhos destes profissionais variou de sete meses a 41 anos de idade, sendo que 64,3\% (45) deles encontramse com idade acima de 20 anos. 
Quanto à categoria profissional do grupo estudado, duas são enfermeiras, sete enfermeiras obstétricas, oito técnicas em enfermagem e 13 auxiliares de enfermagem.

Tabela 2. Distribuição dos profissionais de enfermagem das maternidades de Rio Branco (AC), segundo a idade, estado conjugal e número de filhos. Rio Branco, 2005

\begin{tabular}{llcc}
\hline Variáveis & Categorias & F & \% \\
\hline Idade/anos & $20-30$ & 06 & 20 \\
& $31-40$ & 07 & 23,3 \\
& $41-50$ & 12 & 40 \\
& $51-60$ & 04 & 13,3 \\
Estado conjugal & 61 e mais & 01 & 3,3 \\
& & & \\
& Casada(o) & 13 & 43,3 \\
& Mora junto & 02 & 6,7 \\
& Solteira & 03 & 10 \\
& Separada & 04 & 13,3 \\
& Divorciada & 05 & 16,7 \\
& Viúva & 03 & 10 \\
& & & \\
Número de filhos & Nenhum & 02 & 6,7 \\
& Um & 06 & 20 \\
& Dois & 10 & 33,3 \\
& Três & 08 & 26,7 \\
& Quatro & 01 & 3,3 \\
& Cinco & 02 & 6,7 \\
& Seis & 01 & 3,3 \\
\hline
\end{tabular}

A renda familiar (Tabela 3), entre as enfermeiras, está entre $\mathrm{R} \$ 1.500,00$ e $\mathrm{R} \$$ 10.000,00, enquanto para os profissionais de enfermagem de nível médio de ensino (técnicas e auxiliares de enfermagem) a renda familiar está entre $\mathrm{R} \$ 500,00$ e $\mathrm{R} \$ 2.200,00$. Ao observarmos a média da renda familiar por categoria, encontramos: $\mathrm{R} \$ 3.988,89$ para enfermeira, $\mathrm{R} \$ 1.550,00$ para a técnica em enfermagem e $\mathrm{R} \$ 1.023,08$ para a auxiliar de enfermagem. Vale lembrar que o valor do salário mínimo no momento da coleta de dados era de $\mathrm{R} \$ 300,00$.

A remuneração, nas instituições pesquisadas, das enfermeiras variou entre $\mathrm{R} \$ 1.200,00$ e $\mathrm{R} \$ 2.900,00$, entre os profissionais de enfermagem de nível médio variou de $\mathrm{R} \$ 400,00$ a R\$1.200,00, como mostra a Tabela 4. 
Tabela 3. Distribuição dos profissionais de enfermagem das maternidades de Rio Branco (AC), segundo a renda familiar. Rio Branco, 2005

\begin{tabular}{lccc}
\hline & \multicolumn{3}{c}{ Profissionais de Enfermagem } \\
\cline { 2 - 4 } RENDA FAMILIAR (R\$) & Enfermeira & Téc. Enfermagem & Aux. Enfermagem \\
\hline 500,00 a 1.500,00 & 01 & 05 & 12 \\
$1.600,00$ a $2.500,00$ & 01 & 03 & 01 \\
$2.600,00$ a $3.500,00$ & 02 & - & - \\
$3.600,00$ a $4.500,00$ & 03 & - & - \\
$4.600,00$ a $5.500,00$ & 01 & - & - \\
Acima de 5.500,00 & 01 & $\mathbf{0 8}$ & $\mathbf{1 3}$ \\
TOTAL & $\mathbf{0 9}$ & & \\
\hline
\end{tabular}

Ao observarmos a Tabela 4, podemos verificar que a remuneração dos profissionais da instituição "seringueira” (A) é inferior à remuneração da instituição “castanheira” (B). Este fato torna-se mais claro, quando realizamos as médias salariais por categoria para cada instituição, evidenciado na Figura 1.

Tabela 4. Distribuição dos profissionais de enfermagem das maternidades de Rio Branco (AC), segundo a remuneração na instituição pesquisada. Rio Branco, 2005

\begin{tabular}{lcccccc}
\hline & \multicolumn{6}{c}{ Profissionais de Enfermagem } \\
\cline { 2 - 7 } REMUNERAÇÃO NA & \multicolumn{2}{c}{ Enfermeira } & \multicolumn{2}{c}{ Téc. Enfermagem } & Aux. Enfermagem \\
INSTITUIÇÃO (R\$) & A* & B** & A & B & A & B \\
\hline 0 a 500,00 & - & - & 01 & 02 & 02 & 02 \\
510,00 a 1.000,00 & - & - & 03 & - & 04 & 04 \\
$1.100,00$ a 1.500,00 & 02 & 01 & - & 02 & - & 01 \\
$1.600,00$ a 2.000,00 & - & 01 & - & - & - & - \\
$2.100,00$ a 2.500,00 & - & 03 & - & - & - & - \\
$2.600,00$ a 3.000,00 & - & 02 & - & - & - & - \\
TOTAL & $\mathbf{0 2}$ & $\mathbf{0 7}$ & $\mathbf{0 4}$ & $\mathbf{0 4}$ & $\mathbf{0 6}$ & $\mathbf{0 7}$ \\
\hline
\end{tabular}

* maternidade "seringueira"; ** maternidade "castanheira"

Quanto ao nível educacional dos profissionais de enfermagem que trabalham na assistência ao parto, encontramos que 09 possuem educação superior (Enfermagem), 07 deles cursaram pós-graduação em programas lato sensu. As técnicas em enfermagem (08) possuem ensino médio completo, contudo cinco delas concluíram a educação básica no supletivo. Das 
13 auxiliares de enfermagem que trabalham nestas instituições, 10 possuem o ensino médio completo, duas possuem ensino médio incompleto e uma possui o ensino fundamental completo. Apenas três auxiliares de enfermagem cursaram o ensino regular, dez destas profissionais freqüentaram o supletivo para concluir seus estudos. Do total dos profissionais de enfermagem entrevistados, 50\% (15) cursaram supletivo.

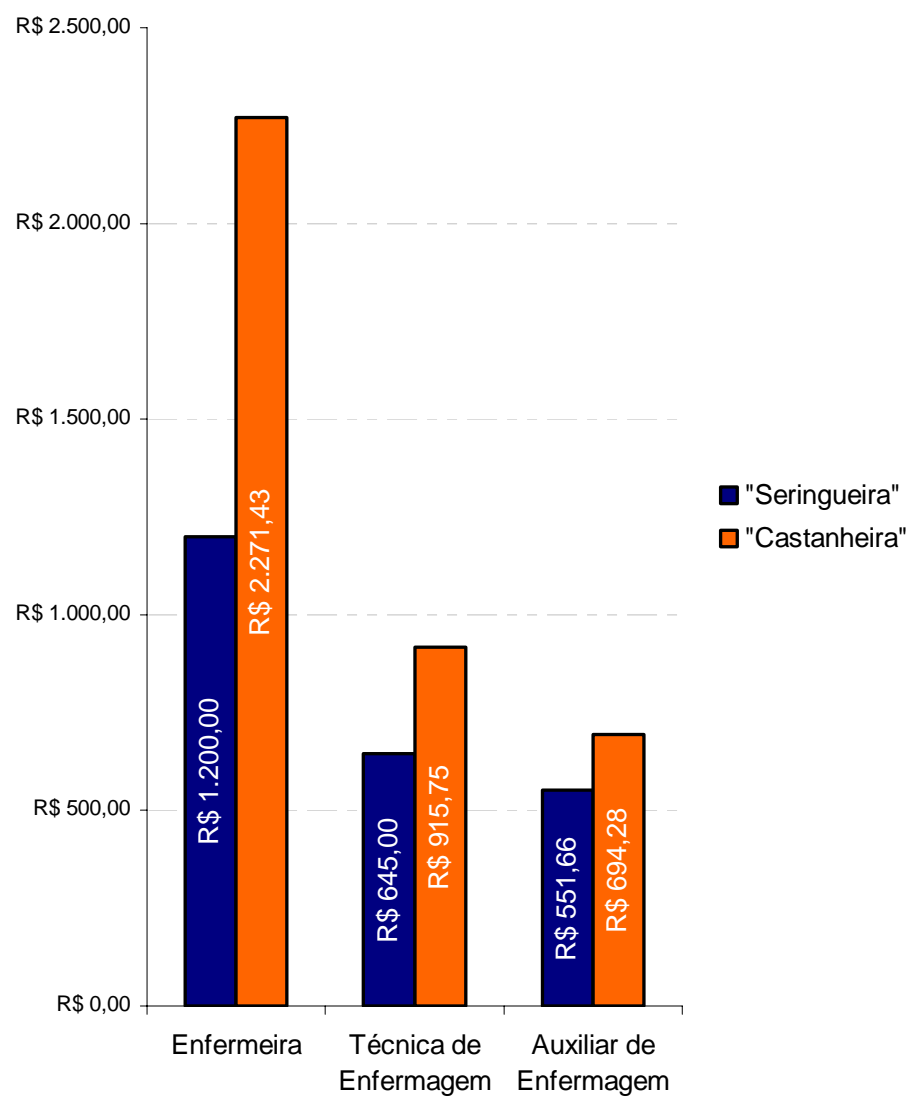

Figura 1. Média da remuneração salarial dos profissionais de enfermagem das maternidades de Rio Branco (AC)

O tempo de formação profissional da equipe de enfermagem das instituições investigadas está apresentado na Tabela 5. É importante ressaltar que todos os profissionais com formação em técnico em enfermagem já possuíam vários anos de formado como auxiliares de enfermagem. Observamos que cinco técnicas possuíam formação em auxiliar de enfermagem entre 06 e 13 anos, e três delas eram formadas em auxiliar entre 24 e 29 anos. 
Levando em conta o tempo de formado como auxiliar de enfermagem, encontramos $60 \%$ (18) dos profissionais com mais de 10 anos de formação profissional.

Tabela 5. Distribuição dos profissionais de enfermagem das maternidades de Rio Branco (AC), segundo os anos de formação. Rio Branco, 2005

\begin{tabular}{lccc}
\hline & \multicolumn{3}{c}{ Profissionais de Enfermagem } \\
\cline { 2 - 5 } ANOS DE FORMAÇÃo & Enfermeira & Téc. Enfermagem & Aux. Enfermagem \\
\hline Menos de 1 ano & - & 04 & - \\
1 a 2 anos & 02 & 01 & 01 \\
3 a 4 anos & - & 02 & 01 \\
5 a 6 anos & 01 & - & - \\
7 a 8 anos & 03 & - & 03 \\
9 a 10 anos & - & - & 01 \\
Acima de 10 anos & 03 & 01 & 07 \\
TOTAL & $\mathbf{0 9}$ & $\mathbf{0 8}$ & $\mathbf{1 3}$ \\
\hline
\end{tabular}

Das nove enfermeiras entrevistadas, sete cursaram especialização em enfermagem obstétrica, curso oferecido pela Universidade Federal do Acre (UFAC), com financiamento da Área Técnica da Saúde da Mulher do Ministério da Saúde. Três enfermeiras realizaram a especialização com carga horária de 510 horas, e quatro realizaram esta especialização em enfermagem obstétrica com carga horária de 495 horas. Além deste curso específico da área de saúde da mulher, três enfermeiras possuem o curso de especialização em Formação Pedagógica em Educação Profissional na Área da Saúde: Enfermagem, com carga horária de 660 horas.

A carga horária média semanal de trabalho destes profissionais é de 63,37 horas, variando de 36 a 116 horas semanais, sendo que 26 (86,66\%) deles trabalham acima de 40 horas semanais. A longa jornada de trabalho destes profissionais é justificada, quando se constata que 12 (40\%) deles trabalham em mais de uma instituição, como mostra a Figura 2. Dos 12 profissionais das maternidades de Rio Branco que possuem dois ou três empregos, apenas dois trabalham na mesma área, ou seja, trabalham em obstetrícia nas duas maternidades. Os demais profissionais trabalham em outras áreas da assistência, como em 
unidades de internação de hospitais gerais, em ambulatórios, em módulos de saúde da família, em unidades de emergência de adulto ou em escola de enfermagem (curso de técnico e auxiliar de enfermagem).
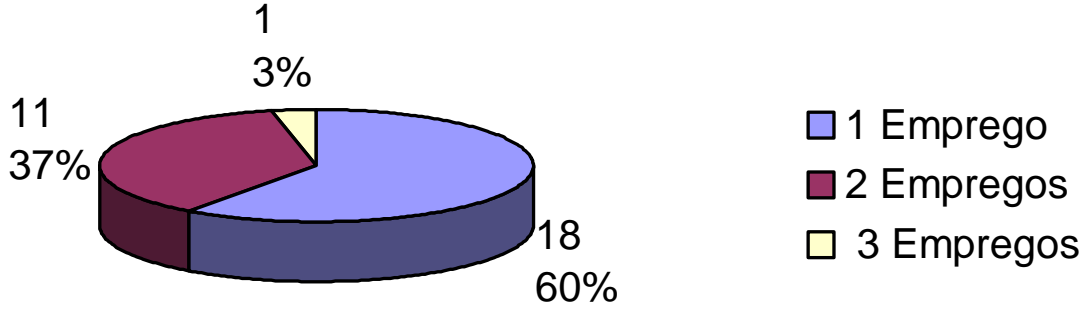

Figura 2. Distribuição dos profissionais de enfermagem das maternidades de Rio Branco (AC), segundo o número de empregos.

O tempo de experiência profissional no atendimento a mulheres em trabalho de parto e parto, conforme mostra a Tabela 6, variou de 04 a 384 meses com uma média de 130,8 meses. Observa-se que a categoria profissional de maior tempo de experiência na área é a de técnicas e auxiliares de enfermagem (média de 171,23 meses). Em relação à categoria das enfermeiras obstétricas, o tempo médio de trabalho na área foi de 80,57 meses (Tabela 6).

Dos profissionais de enfermagem que possuem experiência profissional na área, encontramos que 32\% (08) destes profissionais trabalharam em apenas uma maternidade, 36\% (09) trabalharam em duas maternidades, 24\% (6) trabalharam em três, e $8 \%$ (2) adquiriram sua experiência profissional em quatro maternidades distintas. As maternidades são da cidade de Rio Branco, dos municípios do interior do Estado do Acre e de outros Estados.

É importante ressaltar que dos 30 profissionais que trabalham na assistência à mulher no trabalho de parto e parto, 25 (83,8\%) disseram que foram treinados ou capacitados 
para realizarem o parto. Os cinco profissionais que não realizam partos são três auxiliares de enfermagem que apenas auxiliam no atendimento à mulher, e duas enfermeiras que são responsáveis pela supervisão e gerenciamento da assistência de enfermagem.

Tabela 6. Distribuição dos profissionais de enfermagem das maternidades de Rio Branco (AC), segundo o tempo de trabalho na assistência ao parto. Rio Branco, 2005

\begin{tabular}{|c|c|c|c|c|c|}
\hline \multirow[b]{2}{*}{ TEMPO DE TRABALHO } & \multicolumn{4}{|c|}{ Profissionais de Enfermagem } & \multirow[b]{2}{*}{ TOTAL } \\
\hline & Enf. Obst. & Enfermeira & Téc. Enf. & Aux. Enf. & \\
\hline Menor que 12 meses & - & 01 & 01 & - & 02 \\
\hline 12 a 24 meses & 01 & - & - & 03 & 04 \\
\hline 24 a 36 meses & - & 01 & - & - & 01 \\
\hline 36 a 48 meses & 01 & - & - & - & 01 \\
\hline 48 a 60 meses & - & - & - & - & - \\
\hline 60 a 72 meses & 02 & - & - & 01 & 03 \\
\hline 72 a 84 meses & 01 & - & - & - & 01 \\
\hline 84 a 96 meses & 01 & - & - & - & 01 \\
\hline 96 a 108 meses & - & - & - & - & - \\
\hline 108 a 120 meses & - & - & 01 & 01 & 02 \\
\hline Acima de 120 meses & 01 & - & 06 & 08 & 15 \\
\hline TOTAL & 07 & 02 & 08 & 13 & 30 \\
\hline
\end{tabular}

Dos 25 profissionais que realizam partos, conforme mostra a Tabela 7, sete são enfermeiras obstétricas cuja capacitação foi realizada por meio de curso de especialização em obstetrícia em programa de pós-graduação lato sensu, contudo dois destes profissionais disseram que já haviam recebido treinamento para realizar parto, durante o curso de auxiliar de enfermagem, e que atenderam ao parto antes de serem enfermeiras, e uma enfermeira obstétrica referiu que acompanhou uma parteira durante cinco meses, antes de freqüentar o curso de especialização em obstetrícia.

Outros sete profissionais (duas técnicas e cinco auxiliares de enfermagem) informaram que aprenderam a fazer parto em situações diversas como em cursos de auxiliar de enfermagem, de parteira profissional, de reciclagem ou atualização oferecidos pelas instituições onde trabalham, e pelo treinamento com outros profissionais, quer seja o médico, a enfermeira ou outra parteira. Este treinamento, segundo as informantes, acontecia durante a 
jornada de trabalho, elas explicaram ainda que o profissional que estava sendo treinado acompanhava e era acompanhado pelos profissionais que já trabalhavam na assistência ao parto na maternidade, e, em geral, era colocada a pessoa em treinamento junto com o profissional considerado pela instituição como mais experiente.

Tabela 7. Distribuição dos profissionais de enfermagem das maternidades de Rio Branco (AC), segundo o tipo de treinamento para realizar partos. Rio Branco, 2005

\section{Profissionais de Enfermagem}

TIPO DE TREINAMENTO Enf. Obst. $\mathrm{N}=7 \quad$ Téc. Enf. $\mathrm{N=8} \quad$ Aux. Enf. $\mathrm{N=10}$ TOTAL N=25

\begin{tabular}{lcccc}
\hline Especialização em Obstetrícia & 07 & - & - & $\mathbf{0 7}$ \\
Auxiliar de Enfermagem & 02 & 01 & 02 & $\mathbf{0 5}$ \\
Parteira Tradicional & - & - & 02 & $\mathbf{0 2}$ \\
Reciclagem & - & 01 & 01 & $\mathbf{0 2}$ \\
Treinamento parteira/médico & 01 & 08 & 09 & $\mathbf{1 8}$ \\
\hline
\end{tabular}

O curso de parteira tradicional, ainda vigente no Estado do Acre, é oferecido a pessoas que desejam realizar parto ou que já realizam os partos numa determinada comunidade, onde não existem instituições de saúde que prestam assistência a essa população, ou mesmo em regiões da floresta de difícil acesso.

Cabe ressaltar que dos 25 profissionais treinados, 11 (44\%) deles (seis técnicas em enfermagem e cinco auxiliares) aprenderam a fazer parto apenas em treinamentos que variaram de 10 dias a 2 anos, com outros profissionais.

Quanto ao compromisso com a atualização da prática profissional, nos últimos cinco anos, a Tabela 8 revela que os programas que tiveram maior freqüência, 9 (28,1\%), foram sobre Assistência ao Parto Humanizado com uma carga horária de 20 horas de estudos, seguido de Reanimação Neonatal com 7 (21,8\%) profissionais cujo treinamento foi despendido de 20 a 40 horas. Por outro lado, pode ser observado ainda, na Tabela 8, que a categoria profissional que mais buscou aprimoramento profissional foi a de enfermeiras obstétricas, e os conteúdos que mais foram contemplados dizem respeito ao conhecimento 
relacionado a urgências e emergências obstétricas, alto risco e reanimação neonatal.

Tabela 8. Distribuição dos profissionais de enfermagem das maternidades do município de Rio Branco (AC), segundo os cursos de atualização realizados nos últimos cinco anos. Rio Branco, 2005

\begin{tabular}{|c|c|c|c|c|c|}
\hline \multirow[b]{2}{*}{ CURSO DE ATUALIZAÇÃO } & \multicolumn{4}{|c|}{ Profissionais de Enfermagem } & \multirow[b]{2}{*}{ TOTAL } \\
\hline & Enf. & Enf. Obst. & Téc. Enf. & Aux. Enf. & \\
\hline 1. Assistência ao Parto Humanizado (20hs) & - & 03 & 03 & 03 & 09 \\
\hline 2-Gestação e Parto de Alto Risco (20hs) & - & 03 & - & 01 & 04 \\
\hline 3-Partograma (20hs) & - & 03 & - & - & 03 \\
\hline 4-Complicações no Parto (20hs) & - & 01 & - & - & 01 \\
\hline 5-Emergências Obstétricas (20hs) & - & 02 & - & - & 02 \\
\hline 6-Urgência Materna (20hs) & - & 01 & - & - & 01 \\
\hline 7-Reanimação Neonatal (20/40hs) & 01 & 04 & - & 02 & 07 \\
\hline 8-Aleitamento Materno (20/80hs) & - & 02 & 01 & 02 & 05 \\
\hline TOTAL & 01 & 19 & 04 & 08 & 32 \\
\hline
\end{tabular}

Com relação à participação dos profissionais em eventos científicos na área, apenas seis deles (01 enfermeira, 01 enfermeira obstétrica, 02 técnicas e 02 auxiliares de enfermagem) relataram que participaram de eventos realizados em Rio Branco e três eventos realizados em outros Estados. Os eventos foram: Seminário de Aleitamento Materno (AC), Encontro de Mortalidade Materna (AC), Violência contra a Mulher (AC), Congresso de Ginecologia e Obstetrícia (RO), Encontro de Parteiras Tradicionais (GO) e Congresso Materno-Infantil (SE).

No que se refere à realização do parto, como uma prática rotineira no trabalho dos profissionais estudados, encontramos que dos 25 profissionais que foram preparados para realizarem o parto, 17 (68\%) deles estavam realizando partos nas maternidades pesquisadas, ou seja, quatro técnicas em enfermagem, seis auxiliares de enfermagem e sete enfermeiras obstétricas. É importante ressaltar que, para os oitos profissionais restantes (quatro técnicas e quatro auxiliares de enfermagem), tal prática não mais faz parte de suas atribuições nas instituições estudadas, embora reforçassem que por muitos anos o fizeram e, na atualidade, somente realizam o parto em situações de grande movimento na maternidade ou em situações 
em que a parturiente chega à maternidade em período expulsivo, e os profissionais responsáveis por realizar o parto (enfermeiras obstétricas e médicos) não estão próximos à parturiente.

Quanto aos tipos de procedimentos que cada um dos estudados desenvolvia em suas práticas no atendimento ao parto normal, pudemos identificar que os 25 profissionais afirmaram que ao fazer o parto realizam episiotomia e episiorrafia, 17 (68\%) deles afirmaram fazer parto gemelar e 15 (60\%), parto em apresentação pélvica.

No que se refere à administração de ocitócicos, todos disseram que indicariam em algum momento do trabalho de parto e parto, sendo que 21 (84\%) profissionais disseram fazer sua indicação, no segundo período do parto, para o encurtamento do período expulsivo, 11 (44\%) profissionais afirmaram que indicariam ocitócico após a saída da placenta, no quarto período do parto nos casos de hemorragia, e 08 (32\%) disseram indicar o ocitócito para acelerar o trabalho de parto na presença de bolsa rota com dilatação avançada, no caso de amniorrexe prematura, em trabalho de parto demorado e na ausência de dinâmica uterina. Os profissionais explicaram que a utilização dessa medicação somente poderia ser indicada por eles no caso de ausência do médico, visto que, nas instituições pesquisadas, há médicos nas 24 horas do plantão, e a responsabilidade legal pela prescrição de ocitócico fica a cargo deste profissional.

Quanto à função desempenhada por cada categoria profissional da enfermagem na assistência à mulher, durante o trabalho de parto e parto, os profissionais da maternidade “seringueira” informaram que:

a) Enfermeira: é responsável pelo gerenciamento e supervisão da assistência e pelo atendimento aos pacientes graves (parturiente, puérpera e RN).

b) Técnicas e auxiliares de enfermagem: realizam exame para admissão da 
gestante, prestam assistência à parturiente no pré-parto (verificam pressão arterial, auscultam Batimentos Cardiofetais (BCF), toque obstétrico, colhem sangue para exame, anotação de enfermagem da admissão, dos procedimentos realizados e do parto), apoio psicológico, limpeza dos leitos e mesa do parto, reposição do material diariamente (roupa, instrumental e medicação), administração das medicações prescritas, higiene da parturiente e puérpera, realizam o parto, preparam a sala para o parto, preparam instrumental utilizado no parto para esterilização, preparam a parturiente para cesárea, chamam o médico quando observam uma intercorrência, são responsáveis pelo preenchimento da declaração de nascidos vivos do $\mathrm{RN}$ e encaminham a puérpera ao alojamento conjunto.

Enquanto os profissionais da maternidade “castanheira” disseram que suas funções na assistência são:

a) Enfermeira obstétrica: é responsável pela assistência prestada em todo o centro obstétrico, presta assistência à parturiente no pré-parto (ausculta BCF, verifica dinâmica uterina, faz toque obstétrico, verifica pressão arterial), realiza o parto, auxilia o médico quando ele realiza o parto, presta assistência aos pacientes graves, é responsável pelo controle das medicações psicotrópicas, solicita reposição de materiais e medicamentos e supervisiona a equipe de enfermagem.

b) Técnicas e auxiliares de enfermagem: acompanham o médico durante a admissão da gestante, auxiliando nos procedimentos e orientações necessárias (auscultam BCF, verificam pressão arterial), administram as 
medicações prescritas, acompanham as parturientes nos exames, auxiliam o médico no parto, preparam a parturiente para cesárea (tricotomia se necessário, troca de roupa), limpam os leitos no pré-parto e a mesa da sala de parto, preparam a sala para o parto, quando observam intercorrência chamam a enfermeira obstétrica, realizam a higiene da puérpera e encaminham a puérpera para o alojamento conjunto. Realizam o parto numa emergência, quando os médicos e as enfermeiras obstétricas estão impossibilitados (somente aquelas que foram treinadas).

\subsection{Atenção obstétrica: descrição do observado}

Diante da observação contextual, foi possível constatar que as instituições de saúde de Rio Branco que prestam assistência à mulher, durante o trabalho de parto e parto, não permitem, rotineiramente, a presença de acompanhante durante o processo do nascimento. Na maternidade “castanheira”, apenas as parturientes adolescentes podem permanecer com acompanhante, no entanto, este fato só acontece quando solicitado pela mesma e avaliada a possibilidade pela assistente social. Durante o período de observação, presenciamos na maternidade “castanheira” uma parturiente de 16 anos acompanhada no préparto pela mãe, enquanto na maternidade "seringueira" não observamos a presença de acompanhante em nenhuma fase do processo de nascimento.

Foi possível ainda observar que a hidratação das parturientes é liberada nas duas instituições, sendo suspensa apenas quando há a indicação de cesárea. O tipo de alimentação fornecida é a dieta líquida. Por outro lado, verificamos que, na maternidade "seringueira”, a dieta da parturiente é suspensa, quando a dilatação cervical atinge em torno de sete a oito centímetros. 
O local da realização do parto, nas duas instituições, é a sala de parto que tem uma mesa cirúrgica. A posição das mulheres no parto, adotada nas duas instituições, é em posição de litotomia, com o dorso materno na horizontal, as coxas fletidas em abdução e sustentadas por perneiras. Quanto às anotações de enfermagem, observamos que os profissionais, após a execução dos procedimentos, realizam a anotação ou registro dos mesmos, contudo estas se apresentam pouco detalhadas, muitas vezes não descrevem a real situação da parturiente.

A equipe de enfermagem que assiste o trabalho de parto e parto na maternidade “seringueira” é composta por duas enfermeiras, quatro técnicas em enfermagem e seis auxiliares de enfermagem. Verificamos que as enfermeiras realizam apenas a supervisão e o gerenciamento da unidade. Na maternidade "castanheira”, a equipe é formada por seis enfermeiras obstétricas que são responsáveis pelo acompanhamento do trabalho de parto e realização do mesmo, por quatro técnicas em enfermagem e por sete auxiliares de enfermagem que auxiliam no acompanhamento do trabalho de parto e, esporadicamente, na realização do parto em situações de movimento intenso na maternidade.

\subsubsection{A admissão da parturiente}

Foram observados, durante o período de coletas de dados nos turnos manhã (1), tarde (1) e noite (2) nas duas maternidades, 14 exames de admissão, dos quais 10 aconteceram na maternidade "seringueira” e os quatros restantes, na maternidade “castanheira”.

Observamos que, em uma maternidade, o diagnóstico de trabalho de parto é de responsabilidade da equipe de enfermagem, enquanto na outra instituição fica a cargo do médico. Foi ainda observado que, nas duas instituições estudadas, todas as fichas de Autorização de Internação Hospitalar (AIH) são preenchidas e assinadas pelos médicos.

A Tabela 9 apresenta a freqüência das atividades realizadas durante a admissão de 
14 gestantes pelos profissionais de saúde, nas instituições estudadas.

Tabela 9. Distribuição de freqüências das atividades realizadas pelos profissionais de saúde das maternidades de Rio Branco (AC), segundo a categoria profissional, durante a admissão de 14 gestantes observadas. Rio Branco, 2005

\section{Profissionais de Enfermagem}

\section{Atividade}

Encaminha a gestante para sala de exame

Ajuda a gestante a subir e descer da mesa de exame

Posiciona a gestante para exame

Ausculta do BCF:

Freqüência

Localização

Ritmo

Toque vaginal:

Dilatação do colo

Esvaecimento do colo

Membranas

Apresentação fetal

Posição fetal

Descida fetal

Avaliação da bacia

Diagnóstico de trabalho de parto

Anotações/registro prontuário

AIH

Anamnese completa

Anamnese incompleta

Solicita o cartão do pré-natal

Palpação

Pressão arterial

Dinâmica uterina

Exame físico

Encaminha para banho

Oferece camisola

Faz referência diante de problemas

TOTAL
8

5

14

Téc. Enf. Aux. Enf. Médico

Outros*

TOTAL

8

14

1

8

5

14

1

5

$-$

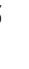

3

$-$

5

5

14

5

5

14

14

14

14

$-$

$-$

14

13

$5 \quad 5$

11

3

4

3

11

11

11

$\begin{array}{lll}4 & 3 & 7\end{array}$

$\begin{array}{lll} & \\ - & 2\end{array}$

$\begin{array}{lll}4 & 3 & 7\end{array}$

$\begin{array}{lll}2 & 4 & 7\end{array}$

3

7

- 5

5

2

4

3

3

3

1

11

53

58

87

209

* enfermeira obstétrica (docente) e acadêmicos de enfermagem da UFAC, presentes apenas na maternidade "seringueira”. 
Dentre as atividades realizadas, verificamos que o encaminhamento para a sala de exames, auxílio na colocação e posicionamento da gestante na mesa de exames, ausculta dos batimentos cardiofetais (BCF), toque vaginal e definição do diagnóstico do trabalho de parto foram aqueles efetuados para todas as gestantes.

Por outro lado, observamos que a anamnese, enquanto procedimento de coleta de informações sobre a gestação e estado atual da mesma, foi realizada de forma completa em apenas sete casos de admissão, e as demais ocorreram de forma incompleta, bem como a solicitação do cartão de pré-natal que aconteceu para apenas sete gestantes.

Da mesma forma, observamos que, para apenas cinco gestantes, foram verificados a localização e o ritmo do BCF, e durante o toque vaginal não foram avaliadas a posição e descida fetal como também a bacia materna de nenhuma gestante. Chama a atenção ainda, nos dados da Tabela 9, que a pressão arterial foi auferida em apenas sete gestantes.

Foi possível constatar também que, nas maternidades estudadas, os procedimentos como tricotomia e enema foram abolidos como prática rotineira na obstetrícia.

Ao analisarmos a relação entre categoria profissional e atividade realizada, pudemos constatar que tanto a enfermeira como a enfermeira obstétrica são elementos não participativos da admissão da gestante nas maternidades estudadas. Durante o período observado, coube às técnicas e auxiliares de enfermagem (pessoal de enfermagem de nível médio de ensino) a responsabilidade de executar quase todos os tipos de atividades realizadas durante a admissão.

Vale destacar que tais profissionais executaram, durante o período de observação, desde atividades de pequena complexidade (encaminhamento da gestante à sala de exame, auxílio na colocação e posicionamento na mesa ginecológica) até aquelas de maior complexidade como a ausculta do BCF e toque vaginal.

Outro dado que chama a atenção se refere ao papel que outros profissionais 
(docente: enfermeira obstétrica e acadêmicos de enfermagem) que não fazem parte do quadro fixo da maternidade "seringueira” exercem no atendimento à gestante, durante a internação. Como constatado na Tabela 9, estes profissionais se responsabilizam pela realização de quase todos os tipos de atividades da internação. Eles realizaram atividades de maior complexidade como dinâmica uterina (5), ausculta do BCF (5), toque vaginal (5), diagnóstico de trabalho de parto (5) e palpação (4).

Interessante observar que foram apenas os acadêmicos de enfermagem que realizaram a dinâmica uterina, constatando que esta não é uma prática realizada na admissão da gestante por nenhuma categoria profissional, nas maternidades estudadas.

Ressaltamos ainda a referência, de uma gestante para a avaliação do médico, feita por uma auxiliar de enfermagem da maternidade "seringueira", quando a mesma detectou prematuridade e queixa de perda de líquido amniótico.

Quando analisamos o número geral de atividades realizadas, durante a coleta de dados, observamos que $72,25 \%$ do total das atividades da admissão das parturientes nas instituições estudadas, durante o período de coleta de dados, foram realizadas pela equipe de enfermagem (técnicas, auxiliares e estudantes de enfermagem).

No entanto, quando analisamos tais dados de acordo com a instituição, verificamos, como mostra a Tabela 10, que na maternidade “castanheira” as atividades de ausculta do BCF (75\%), toque vaginal (100\%) e diagnóstico de trabalho de parto (100\%) cabem quase que exclusivamente à categoria médica, enquanto na outra instituição tais atividades são de responsabilidade do pessoal de enfermagem (nível médio e acadêmicos de enfermagem). Estas diferenças mostraram-se significantes pelo teste exato de Fisher, em que p foi 0,011 e 0,016, ou seja, a divisão do trabalho ocorre de forma diferente em cada instituição. 
Tabela 10. Distribuição de freqüências das atividades, ausculta do BCF, toque vaginal e diagnóstico de trabalho de parto, realizados pelos profissionais de saúde das maternidades de Rio Branco (AC), segundo a categoria profissional, durante a admissão de 14 gestantes observadas. Rio Branco, 2005

\begin{tabular}{|c|c|c|c|c|c|c|c|}
\hline \multirow[b]{2}{*}{ Maternidade } & \multicolumn{2}{|c|}{ Profissional } & \multicolumn{2}{|c|}{ Nível médio } & \multicolumn{2}{|c|}{ Alunos } & \multirow[t]{2}{*}{$\mathbf{p}$} \\
\hline & $\mathrm{n}$ & $\%$ & $n$ & $\%$ & $\mathrm{n}$ & $\%$ & \\
\hline \multicolumn{8}{|c|}{$\begin{array}{c}\text { Ausculta do BCF } \\
\end{array}$} \\
\hline "seringueira" & - & - & 5 & 50 & 5 & 50 & \multirow{2}{*}{0,016} \\
\hline "castanheira” & 3 & 75 & 1 & 25 & - & - & \\
\hline \multicolumn{7}{|c|}{ Toque vaginal } & \multirow{3}{*}{0,011} \\
\hline "seringueira” & 1 & 10 & 4 & 40 & 5 & 50 & \\
\hline "castanheira" & 4 & 100 & - & - & - & - & \\
\hline \multicolumn{7}{|c|}{ Diagnóstico de trabalho de parto } & \\
\hline "seringueira” & 1 & 10 & 4 & 40 & 5 & 50 & \multirow{2}{*}{0,011} \\
\hline "castanheira" & 4 & 100 & - & - & - & - & \\
\hline
\end{tabular}

\subsubsection{O trabalho de parto}

$\mathrm{O}$ atendimento dos profissionais no trabalho de parto foi observado durante oito turnos, sendo dois turnos da manhã, dois da tarde e quatro noturnos para cada maternidade estudada. Assim foram realizadas observações de 34 parturientes em trabalho de parto, sendo que 19 eram da maternidade “castanheira” e 15 parturientes da maternidade "seringueira”. A Tabela 11 apresenta a freqüência das atividades realizadas durante a assistência ao trabalho de parto, de acordo com a categoria profissional.

Foi possível verificar que, no período de observação, a utilização de partograma, cardiotocografia, palpação abdominal e avaliação vesical não fizeram parte da rotina das maternidades estudadas, visto que nenhuma parturiente foi submetida a eles.

As atividades de maior freqüência realizadas no acompanhamento do trabalho de parto das 34 parturientes nas maternidades estudadas foram a ausculta do BCF (65 vezes) e o 
toque vaginal (46 vezes). Cabe destacar que a ausculta do BCF se dirigia principalmente à contagem da freqüência, e o toque vaginal, à dilatação do colo uterino.

Tabela 11. Distribuição de freqüências das atividades realizadas pelos profissionais de saúde das maternidades de Rio Branco (AC), segundo a categoria profissional, durante a assistência ao trabalho de parto de 34 parturientes observadas. Rio Branco, 2005

\begin{tabular}{|c|c|c|c|c|c|}
\hline \multirow[b]{2}{*}{ Atividade } & \multicolumn{4}{|c|}{ Profissionais de Enfermagem } & \multirow[b]{2}{*}{ TOTAI } \\
\hline & Enf. Obst. & Téc. Enf. & Aux. Enf. & Médico & \\
\hline \multicolumn{6}{|l|}{ Ausculta: } \\
\hline Freqüência & 21 & 2 & 14 & 28 & 65 \\
\hline Localização & 8 & - & - & 3 & 11 \\
\hline Ritmo & - & - & - & - & - \\
\hline \multicolumn{6}{|l|}{ Toque vaginal: } \\
\hline Dilatação do colo & 3 & 3 & 8 & 32 & 46 \\
\hline Esvaecimento do colo & 3 & 2 & 2 & 18 & 25 \\
\hline Membranas & 3 & 2 & 2 & 11 & 18 \\
\hline Apresentação fetal & 3 & 2 & 2 & 10 & 17 \\
\hline Posição fetal & - & - & - & 2 & 2 \\
\hline Descida fetal & - & - & - & 6 & 6 \\
\hline Avaliação da bacia & - & - & - & - & - \\
\hline Administração de medicamentos & 1 & 8 & 7 & - & 16 \\
\hline Amniotomia & 1 & 3 & 3 & 5 & 12 \\
\hline \multicolumn{6}{|l|}{ Dinâmica uterina: } \\
\hline Freqüência & 6 & - & - & 2 & 8 \\
\hline Duração & 6 & - & - & - & 6 \\
\hline Intensidade & 6 & - & - & - & 6 \\
\hline \multicolumn{6}{|l|}{ Uso de medicamentos: } \\
\hline a)Ocitocina: & - & - & - & 7 & 7 \\
\hline b)Dolantina + atropina: & - & - & - & 1 & 1 \\
\hline c)Ampicilina: & - & - & - & 2 & 2 \\
\hline d)Buscopam: & - & - & - & 2 & 2 \\
\hline Estímulo à deambulação: & 5 & 1 & 1 & - & 7 \\
\hline Sinais vitais & 3 & - & 1 & 1 & 5 \\
\hline Apoio/orientação & 4 & - & - & - & 4 \\
\hline Faz referência diante de problemas: & 1 & 1 & 1 & - & 3 \\
\hline \multicolumn{6}{|l|}{ Alívio da dor: } \\
\hline Massagem & 1 & - & - & - & 1 \\
\hline Banho & - & - & - & - & - \\
\hline Respiração & - & - & - & - & - \\
\hline Anestesia & - & - & - & - & - \\
\hline TOTAL & 75 & 24 & 41 & 130 & 270 \\
\hline
\end{tabular}

Pudemos observar a prescrição de ocitocina para sete parturientes, dolantina e 
atropina (1), ampicilina (2) e buscopam (2) nas instituições estudadas, sendo que apenas o médico foi o responsável pela sua indicação.

Quanto à categoria profissional, os dados da Tabela 11 mostram que a enfermeira obstétrica está presente no acompanhamento do trabalho de parto. Esta categoria profissional pertence apenas ao quadro da maternidade “castanheira”. A maioria do controle da dinâmica uterina (6) foi feita pela enfermeira obstétrica, duas foram realizadas pelo médico da mesma maternidade, as demais categorias não realizaram tal atividade.

Um dado que chama a nossa atenção é que na maternidade onde não há a presença da enfermeira obstétrica no acompanhamento do trabalho de parto, atividades como ausculta do BCF, toque vaginal e amniotomia foram realizadas tanto pelas auxiliares e técnicas de enfermagem como pelos médicos.

Durante o período de observação do controle das 34 parturientes em trabalho de parto, observamos que procedimentos não farmacológicos para alívio da dor não fizeram parte da rotina de ambas as instituições estudadas. Presenciamos a realização de massagens em apenas uma parturiente pela enfermeira obstétrica. Por outro lado, constatamos que o estímulo à deambulação foi feito a sete parturientes, destas, a maioria (5) foi realizada pela enfermeira obstétrica.

Identificamos, também, durante a observação das atividades nesta fase do processo do nascimento, algumas condutas tomadas pelos profissionais de enfermagem perante situações em que os mesmos tiveram que tomar decisões, realizar procedimentos para avaliar a evolução do trabalho de parto, fazer orientações, dar apoio à parturiente e sua família. Estas condutas foram tomadas pela auxiliar de enfermagem da maternidade “seringueira” (uma vez) e pela enfermeira obstétrica da maternidade “castanheira” (quatro vezes).

Ao analisarmos a totalidade das atividades realizadas durante a observação das 34 
parturientes, mostradas na Tabela 11, observamos que 51,85\% delas foram feitas pela equipe de enfermagem.

A Tabela 12 apresenta a freqüência dos procedimentos de ausculta do BCF, toque vaginal e amniotomia realizados durante a assistência ao trabalho de parto, por instituição estudada, segundo a categoria profissional.

Tabela 12. Distribuição de freqüências dos procedimentos, ausculta do BCF, toque vaginal e amniotomia, realizados pelos profissionais de saúde das maternidades de Rio Branco (AC), segundo a categoria profissional, durante a assistência ao trabalho de parto de 34 parturientes observadas. Rio Branco, 2005

\begin{tabular}{|c|c|c|c|c|c|c|c|}
\hline \multirow[b]{2}{*}{ Maternidade } & \multicolumn{2}{|c|}{$\begin{array}{l}\text { Profissional } \\
\text { Médico }\end{array}$} & \multicolumn{2}{|c|}{ Enf. Obst. } & \multicolumn{2}{|c|}{ Nível médio } & \multirow{2}{*}{$\mathbf{p}$} \\
\hline & $\mathrm{n}$ & $\%$ & $\mathrm{n}$ & $\%$ & $\mathrm{n}$ & $\%$ & \\
\hline \multicolumn{7}{|c|}{$\begin{array}{l}\text { Ausculta do BCF } \\
\end{array}$} & \multirow{3}{*}{$<0,001$} \\
\hline "seringueira" & 8 & 33,3 & - & - & 16 & 66,7 & \\
\hline “castanheira” & 20 & 48,8 & 21 & 51,2 & - & - & \\
\hline \multicolumn{7}{|c|}{ Toque vaginal } & \multirow{3}{*}{0,001} \\
\hline "seringueira" & 11 & 50 & - & - & 11 & 50 & \\
\hline "castanheira” & 21 & 87,5 & 3 & 12,5 & - & - & \\
\hline \multicolumn{7}{|c|}{ Amniotomia } & \multirow{3}{*}{0,011} \\
\hline "seringueira" & - & - & - & - & 6 & 100 & \\
\hline "castanheira” & 5 & 83,3 & 1 & 16,7 & - & - & \\
\hline
\end{tabular}

Quando analisamos os dados da Tabela 12, verificamos que o procedimento de ausculta do BCF é realizado em 66,7\% dos casos pelo pessoal de enfermagem de nível médio na maternidade "seringueira”, enquanto na outra instituição a freqüência de realização deste procedimento é dividida quase que igualmente entre a categoria médica e a das enfermeiras obstétricas. O toque vaginal é realizado em $87,5 \%$ dos casos pelo médico na maternidade “castanheira”, já na maternidade “seringueira” os profissionais de enfermagem de nível médio e o médico realizam, 50\% cada, tal procedimento. Observamos também que a amniotomia realizada, durante o período da coleta de dados deste estudo, foi $100 \%$ executada na 
maternidade "seringueira" pelo pessoal de enfermagem de nível médio, contra $0 \%$ na maternidade “castanheira”. Nesta maternidade, a amniotomia é realizada pelo médico (83,3\%) e pela enfermeira obstétrica (16,7\%). Estes achados mostraram significantes diferenças pelo teste exato de Fisher, em que p < 0,001 e p 0,002, como evidencia a Tabela 12, revelando que as instituições apresentam formas diferentes na divisão do trabalho.

\subsubsection{Atenção ao parto}

A observação das atividades realizadas pela equipe de saúde, durante o parto, foi feita em seis turnos de plantão, sendo dois no período da manhã, dois à tarde, e dois à noite, em cada instituição estudada. Foram então observados 17 partos normais, dez deles aconteceram na maternidade “seringueira” e sete, na maternidade “castanheira”.

Dentre os partos realizados no período de observação, seis foram assistidos por médico, cinco por técnicas em enfermagem, quatro partos foram por auxiliares de enfermagem e dois por enfermeiras obstétricas.

Quando analisamos qual o profissional que realizou o parto de acordo com a instituição, Tabela 13, observamos que na maternidade “castanheira” 71,43\% dos partos foram realizados por médico, contra $10 \%$ na maternidade "seringueira”, enquanto $90 \%$ dos partos da maternidade "seringueira” foram realizados pelo pessoal de enfermagem de nível médio, contra 0\% da maternidade "castanheira”. Estas diferenças foram significantes pelo teste exato de Fisher, em que $\mathrm{p}<0,001$. Na instituição onde existem enfermeiras obstétricas, elas foram responsáveis por dois dos sete partos ali observados.

Cabe destacar que, nas situações em que era o médico quem atendia ao parto, foram observadas apenas as atividades realizadas pela equipe de enfermagem. Nesses partos, nas duas instituições estudadas, coube à equipe de enfermagem circular a sala de parto, 
oferecer os materiais solicitados, administrar as medicações prescritas, realizar a higiene da puérpera após o parto, levar a mesma ao alojamento conjunto e reorganizar a sala de parto.

Tabela 13. Distribuição de freqüências dos partos realizados pelos profissionais de saúde das maternidades de Rio Branco (AC), segundo a categoria profissional. Rio Branco, 2005

\begin{tabular}{lccccccc}
\hline & \multicolumn{2}{c}{ Profissional } & \multicolumn{2}{c}{ Enf. Obst. } & \multicolumn{2}{c}{ Nível médio } & \multirow{2}{*}{ p } \\
Maternidade & $\mathrm{n}$ & $\%$ & $\mathrm{n}$ & $\%$ & $\mathrm{n}$ & $\%$ & \\
\hline "seringueira" & 1 & 10 & - & - & 9 & 90 & $<0,001$ \\
"castanheira" & 5 & 71,43 & 2 & 28,57 & - & - & \\
\hline
\end{tabular}

Diante dessas observações, as atividades descritas a seguir referem-se apenas àquelas relacionadas aos partos assistidos pela equipe de enfermagem. Assim a Tabela 14 apresenta as freqüências das atividades realizadas pelos profissionais de saúde, durante o parto (segundo período clínico do parto - expulsivo) de 11 parturientes assistidas pela equipe de enfermagem, nas instituições estudadas.

Dentre as atividades de maior freqüência de realização nos 11 partos observados, estão o estímulo ao puxo (10), episiotomia (10), manejo do pólo cefálico (9), anestesia local antes da episiorrafia (8), administração de ocitócico (6) e manobra de Kristeller (5).

Foi possível, ainda, observar que a prescrição de ocitócicos (6) aconteceu nos partos assistidos pelo pessoal de enfermagem de nível médio de escolarização, a técnica de enfermagem indicou uma vez, a auxiliar de enfermagem duas vezes, e o médico prescreveu, para estes partos, três vezes a utilização do medicamento, enquanto nos dois partos realizados pela enfermeira obstétrica este procedimento não foi observado.

Da mesma forma, houve a realização de cinco manobras de Kristeller nos partos assistidos pelo pessoal de enfermagem de nível médio, enquanto nenhuma foi realizada nos partos da enfermeira obstétrica. Tais manobras foram executadas em três partos pelos profissionais de enfermagem e em dois pelo médico. 
Tabela 14. Distribuição de freqüências das atividades realizadas pelos profissionais de saúde das maternidades de Rio Branco (AC), durante a assistência ao parto (período expulsivo) das 11 parturientes observadas. Rio Branco, 2005

\begin{tabular}{|c|c|c|c|c|c|}
\hline \multirow[b]{2}{*}{ Atividade } & \multicolumn{4}{|c|}{ Profissionais de Saúde } & \multirow[b]{2}{*}{ TOTAL } \\
\hline & Enf. Obst. & Téc. Enf. & Aux. Enf. & Médico & \\
\hline Estímulo para puxo & 2 & 4 & 4 & - & 10 \\
\hline Episiotomia & 2 & 4 & 4 & - & 10 \\
\hline Manejo do pólo cefálico & 2 & 4 & 3 & - & 9 \\
\hline Anestesia antes da episiotomia & 2 & 3 & 3 & - & 8 \\
\hline Uso de medicamentos: ocitocina & - & 1 & 2 & 3 & 6 \\
\hline Manobra de Kristeller & - & 1 & 2 & 2 & 5 \\
\hline Proteção do períneo & 2 & - & - & - & 2 \\
\hline Faz referência diante de problemas: & - & - & 1 & - & 1 \\
\hline TOTAL & 10 & 17 & 19 & 5 & 51 \\
\hline
\end{tabular}

A Tabela 15 apresenta as atividades realizadas, durante o terceiro período clínico do parto, a dequitação, dos 11 partos realizados pela equipe de enfermagem, de acordo com a categoria profissional.

O procedimento de maior freqüência de realização foi a episiorrafia (10), seguido da tração controlada do cordão (9) e uso de ergometrina após a saída da placenta (8). Foi observado ainda que o exame da placenta e das membranas ovulares não faz parte da rotina da prática dos profissionais, visto que, dos 11 períodos de dequitação observados, nenhuma vez o procedimento foi realizado.

O manejo do terceiro período se mostrou como um procedimento predominantemente ativo (9) entre os profissionais de saúde estudados, sendo observados apenas dois manejos fisiológicos, os quais foram realizados pelas enfermeiras obstétricas.

Um dado que chama ainda atenção é que a revisão uterina (exploração manual) foi realizada em quatro períodos de dequitação, tanto pela enfermeira obstétrica (1) como pelo pessoal de enfermagem de nível médio (3). A mesma freqüência (4) foi verificada em relação 
à inspeção de vulva, períneo, vagina e cérvix também realizada pelas enfermeiras obstétricas (2) e pelo pessoal de enfermagem de nível médio (2).

Tabela 15. Distribuição de freqüências das atividades realizadas pelos profissionais de saúde das maternidades de Rio Branco (AC), durante a assistência ao parto (dequitação) das 11 parturientes observadas. Rio Branco, 2005

\begin{tabular}{|c|c|c|c|c|c|}
\hline \multirow[b]{2}{*}{ Atividade } & \multicolumn{4}{|c|}{ Profissionais de Saúde } & \multirow[b]{2}{*}{ TOTAI } \\
\hline & Enf. Obst. & Téc. Enf. & Aux. Enf. & Médico & \\
\hline Episiorrafia & 2 & 4 & 4 & - & 10 \\
\hline $\begin{array}{l}\text { Manejo ativo: } \\
\text { Uso de ocitocina: }\end{array}$ & - & 1 & 2 & 3 & 6 \\
\hline Tração controlada do cordão: & - & 5 & 4 & - & 9 \\
\hline $\begin{array}{l}\text { Clampeamento do cordão logo após a } \\
\text { expulsão fetal: }\end{array}$ & - & 3 & 2 & - & 5 \\
\hline 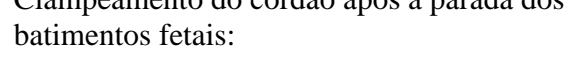 & - & 2 & 2 & - & 4 \\
\hline $\begin{array}{l}\text { Uso de ergometrina após a saída da } \\
\text { placenta: }\end{array}$ & - & 4 & 4 & - & 8 \\
\hline Revisão uterina (exploração manual) & 1 & 1 & 2 & - & 4 \\
\hline Inspeção vulva, períneo, vagina e cérvix & 2 & 1 & 1 & - & 4 \\
\hline Manejo fisiológico & 2 & - & - & - & 2 \\
\hline Anestesia antes da episiorrafia: & - & 1 & 1 & - & 2 \\
\hline Anestesia antes da sutura & - & - & 1 & - & 1 \\
\hline Sutura das lacerações & - & - & 1 & - & 1 \\
\hline Massagem fundo uterino & - & - & 1 & - & 1 \\
\hline Exame da placenta e membranas ovulares: & - & - & - & - & - \\
\hline TOTAL & 7 & 22 & 25 & 3 & 57 \\
\hline
\end{tabular}

\subsubsection{Atenção ao pós-parto}

No pós-parto, observamos as atividades realizadas na primeira hora após o parto, ou seja, o quarto período clínico do parto daqueles 11 partos realizados pela equipe de enfermagem. A Tabela 16 que descreve as atividades nesta fase, de acordo com a categoria 
profissional, evidencia que as mesmas foram realizadas apenas pelas enfermeiras obstétricas.

Tabela 16. Distribuição de freqüências das atividades realizadas pelos profissionais de saúde das maternidades de Rio Branco (AC), durante a assistência ao pós-parto das 11 puérperas observadas. Rio Branco, 2005

\begin{tabular}{lccccc}
\hline \multirow{2}{*}{ Atividade } & \multicolumn{4}{c}{ Profissionais de Saúde } & \\
\cline { 2 - 5 } & Enf. Obst. & Téc. Enf. & Aux. Enf. & Médico & TOTAL \\
\hline Obs. consistência uterina & 2 & - & 1 & - & $\mathbf{3}$ \\
Obs. sangramento & 2 & - & - & - & $\mathbf{2}$ \\
Altura uterina & 2 & - & - & - & $\mathbf{2}$ \\
Pressão arterial & 1 & - & - & - & $\mathbf{1}$ \\
TOTAL & 7 & - & $\mathbf{1}$ & - & $\mathbf{8}$ \\
\hline
\end{tabular}

Vale lembrar que apenas a maternidade "castanheira” possui no seu quadro de funcionários do centro obstétrico a enfermeira obstétrica, logo observamos neste estudo que, na maternidade “seringueira”, o atendimento durante o quarto período do parto é inexistente.

Tabela 17. Distribuição de freqüências das atividades realizadas pelos profissionais de saúde das maternidades de Rio Branco (AC), durante a assistência aos 11 recém-nascidos dos partos observados. Rio Branco, 2005

\begin{tabular}{lccccc}
\hline Atividade & Enf. Obst. & Téc. Enf. & Aux. Enf. & Médico & TOTAL \\
\hline Cortar e clampear o cordão & 2 & 6 & 3 & - & $\mathbf{1 1}$ \\
Secar & - & 5 & 5 & 1 & $\mathbf{1 1}$ \\
$\begin{array}{l}\text { Contato mãe/filho } \\
\text { a) primeira meia hora }\end{array}$ & 2 & 3 & 3 & - & $\mathbf{8}$ \\
Estímulo à amamentação & 2 & - & - & - & $\mathbf{2}$ \\
Oxigenação & - & - & 1 & 1 & $\mathbf{2}$ \\
$\begin{array}{l}\text { Aspiração } \\
\text { Liberar vias aéreas superiores }\end{array}$ & - & - & 1 & 1 & $\mathbf{2}$ \\
Estímulo ao RN com massagem nas costas & - & - & - & 1 & $\mathbf{1}$ \\
$\begin{array}{l}\text { Contato pele a pele } \\
\text { a)primeira meia hora }\end{array}$ & - & - & 1 & - & $\mathbf{1}$ \\
TOTAL & - & - & - & - & - \\
\hline
\end{tabular}


Os cuidados com os recém-nascidos estão apresentados na Tabela 17. Os procedimentos com maior freqüência foram cortar e clampear o cordão umbilical e secar o RN (11), seguido do contato entre mãe e filho na primeira meia hora pós-parto (8).

Podemos ressaltar que o contato pele a pele entre a mãe e seu filho não foi observado neste estudo, e que o estímulo à amamentação (2) foi realizado apenas pelas enfermeiras obstétricas. 
Discussão 


\section{DISCUSSÃO}

\subsection{A equipe de enfermagem}

Os profissionais de enfermagem que prestam atendimento à parturiente nas instituições estudadas em Rio Branco configuram-se como sendo a grande maioria do sexo feminino (96,66\%), convivendo com parceiro sexual, tendo experiência de ter filhos e sendo pessoas que já passaram dos 40 anos de idade. Da mesma forma, foi possível verificar que, além de serem profissionais que atingiram a maturidade pessoal, estes exibem uma longa experiência profissional no atendimento à mulher no ciclo grávido-puerperal. Portanto, o perfil do grupo estudado no município de Rio Branco revela características de pessoas maduras tanto do ponto de vista etário como profissional. A população amostral revela também uma característica muito comum na enfermagem brasileira que é caracterizada por uma extensa carga horária de trabalho, especialmente em decorrência do baixo nível de remuneração, o que leva à procura de dois ou mais empregos.

O conjunto desses profissionais é constituído em sua maioria por auxiliares e técnicos de enfermagem, sendo que as enfermeiras, especialistas ou não em obstetrícia, representaram 30\% deste conjunto populacional.

Os profissionais de enfermagem de nível médio constituem 83,8\% da força de trabalho da enfermagem no Brasil. O que não difere da maioria dos países da América Latina que apresentam uma variação entre 52,7\% e 87,8\% de auxiliares e técnicos na composição da força de trabalho da enfermagem. Apenas o Panamá, Porto Rico e México apresentam índice menor que 50\% para esta parcela de profissionais de enfermagem (PAN AMERICAN HEALTH ORGANIZATION. PAHO, 2005).

As mulheres representam cerca de 73\% dos empregos nas ocupações de saúde no Brasil. A participação feminina na região Norte é de 88,8\%, entre os enfermeiros, e 80,2\%, 
entre os profissionais de enfermagem de nível médio. A média de idade dos profissionais de enfermagem nesta região está em torno de 36 anos (GIRARDI; CARVALHO, 2002).

A condição de trabalho hospitalar em enfermagem é caracterizada por intensa sobrecarga física e mental e envolve extensa carga horária, particularmente em serviços como urgências, cuidados intensivos, recuperação cirúrgica e salas de trabalho de parto. Em todos os serviços, são exigidas da enfermagem grande responsabilidade e uma contínua disponibilidade para com as necessidades dos clientes e sua família. As condições de trabalho das enfermeiras se caracterizam por sobrecarga de trabalho, extensas jornadas, turnos rotativos, trabalho noturno, freqüentes mudanças de serviços e sobrecarga psicológica por manejar situações críticas. A jornada de trabalho da enfermagem mais comum na América Latina é de oito horas diárias e 45 horas semanais, contudo existe uma variação entre seis horas diárias e 30 semanais e nove horas diárias e mais de 50 horas semanais (PAHO, 2005).

A média da carga horária de trabalho da enfermagem encontrada neste estudo $(63,37)$ excede muito a carga horária máxima indicada para os países da América Latina, este fato ocorre devido aos vários empregos desses profissionais.

Os baixos salários encontrados neste estudo não diferem muito dos salários das enfermeiras dos demais países da América Latina. Em geral, os salários das enfermeiras, nesta parte das Américas, são baixos e variáveis por país. Os valores vão desde U\$100 na Nicarágua, passando pelo Brasil com U\$830 e até U\$1.100 na Costa Rica. Os salários dos auxiliares de enfermagem é em média 69,5\% do salário das enfermeiras nestes países (PAHO, 2005).

No Brasil, segundo Girardi e Carvalho (2002), os técnicos e auxiliares recebem em média 41,9\% do salário das enfermeiras. Neste estudo, encontramos que a média dos salários destes profissionais nas instituições de saúde de Rio Branco que atendem ao parto e nascimento corresponde a 33,75\% da média dos salários das enfermeiras. 
De acordo com a definição de profissional qualificado ao atendimento ao parto da Confederação Internacional das Parteiras (ICM), OMS, Federação Internacional de Ginecologia e Obstetrícia (FIGO) (WHO, 2004b), os dados do presente estudo revelam que, na realidade estudada, ou seja, no município de Rio Branco, nem todos os profissionais de enfermagem que exercem sua prática no atendimento ao parto atendem ao perfil traçado naquela definição. Isso porque apenas 07 (28\%) atendem àquele perfil. No Brasil, os profissionais legalmente habilitados para realizar o parto são: médico, enfermeira, enfermeira obstétrica e obstetriz (parteira profissional). À enfermeira, não especialista em obstetrícia, cabe realizar apenas o parto sem distócia e sem episiotomia e episiorrafia.

Para Onofre et al. (1990), a qualificação profissional das enfermeiras é importante e necessária para que possam acompanhar os avanços e as transformações socioeconômicas e tecnológicas, visando à melhoria da assistência prestada à clientela, além da adoção de uma postura mais crítica e reflexiva dos aspectos profissionais e estruturais.

Dentre as possíveis explicações para o número reduzido de pessoal de enfermagem qualificado para o parto, identificado no presente estudo, uma delas pode estar relacionada às dificuldades de acesso profissional para continuidade na sua formação. O Estado do Acre fica distante dos grandes centros universitários do país, o que muitas vezes dificulta e até inviabiliza a saída de estudantes para fazerem sua graduação ou pós-graduação. O único órgão formador em enfermagem no Estado do Acre fica em Rio Branco, a Universidade Federal, portanto esta Universidade passa a ser a única opção para os egressos realizarem tanto a sua formação graduada quanto a pós-graduada. Assim, a qualificação profissional fica restrita àqueles que permanecem na capital do Estado e que disputam as reduzidas vagas dos cursos de especialização oferecidos pela Universidade Federal do Acre (UFAC), os quais são oferecidos esporadicamente na dependência de financiamentos para sua concretização. Cabe ainda destacar que muito recentemente foi criado o primeiro curso de 
graduação em medicina no Estado, ou seja, na UFAC, que ainda não formou nenhuma turma. Este fato reforça a carência de pessoal com qualificação para o atendimento à saúde da população acreana, revelando uma verdadeira crise na formação e qualificação dos profissionais de saúde.

Historicamente o Estado do Acre vivencia a escassez de profissionais da área de saúde, e, principalmente, com formação especializada. Esta situação é ainda mais crítica nos municípios do interior do Estado. A presença de um grande número de parteiras tradicionais vem comprovar essa situação de que, segundo a Secretaria Estadual de Saúde, em 2005, existiam 476 parteiras tradicionais cadastradas no Estado (ACRE. GOVERNO DO ESTADO DO ACRE, 2006).

Em 2004, o número de profissionais de saúde por 1.000 habitantes no Brasil era de 1,42 para médicos, 0,55 para enfermeiros, 0,86 para técnicos em enfermagem e 2,52 para auxiliares de enfermagem. Quando analisamos esses dados por região, encontramos que a região Sudeste possui os maiores índices, apresentando 2,08 médicos por 1.000 habitantes, enquanto a região Norte apresenta os menores índices, 0,57 médico por 1.000 habitantes. No Estado do Acre, estes indicadores são: 0,72 médicos, 0,64 enfermeiros, 0,22 técnicos em enfermagem e 1,9 auxiliares de enfermagem por 1.000 habitantes (BRASIL. MS., 2004b). Tais dados confirmam a carência de profissionais de saúde no Estado sob estudo.

Os números de profissionais de saúde existentes no Brasil não são muito diferentes da maioria dos países da América Latina. O Brasil possui 0,55 enfermeiros para cada 1.000 habitantes (BRASIL. MS., 2004b), enquanto a Bolívia possui 0,16, a Colômbia, 0,57, o Peru, 0,67, a Argentina, 0,59, o Chile, 0,67, o Paraguai, 0,12 e o Uruguai possui 0,9, contudo existem países que apresentam índices bem maiores como Porto Rico que possui 4,25 e Cuba, 7,5 enfermeiros por 1.000 habitantes. Entretanto, esta carência de profissionais de saúde fica ainda mais evidente, quando a comparamos com países desenvolvidos. Os Estados 
Unidos possuem 9,72 enfermeiros por 1.000 habitantes (PAHO, 2005).

O primeiro curso de especialização em enfermagem obstétrica realizado no Estado do Acre foi em 1999. A necessidade desta especialização era sentida há muito tempo, visto que a responsabilidade pela assistência à mulher em processo de trabalho de parto e parto era realizada nas instituições de Rio Branco, apenas por técnicas e auxiliares de enfermagem. Essa realidade começou a mudar após a formação de enfermeiras obstétricas cujo curso só foi possível com o apoio do Ministério da Saúde.

A UFAC, de 1999 a 2003, formou 64 enfermeiras obstétricas no Estado, atualmente estão em curso mais 21 alunas. Cabe ressaltar que para atender à demanda do Estado, as enfermeiras obstétricas formadas ao longo desse período são provenientes também de outros municípios, as quais receberam ajuda de custo para deslocamento e uma bolsa para se manterem em Rio Branco.

Com relação à participação em eventos científicos na área, Urbano (2002) afirma que estamos na era de rápidas mudanças tecnológicas e de obsolescência do conhecimento, o que requer uma constante busca de atualização em outros meios que não o ensino formal, tais como: seminários, congressos, conferências e fontes informatizadas. Contudo o número de eventos científicos na área de saúde da mulher é muito pequeno em Rio Branco e, em geral, os profissionais não valorizam e não prestigiam os poucos eventos realizados.

Neste estudo, identificamos que 7 (77,8\%) enfermeiras não participaram de nenhum evento científico na área, resultado similar ao encontrado no estudo sobre o perfil das enfermeiras que atuam na assistência à gestante, parturiente e puérpera, nas instituições em Sorocaba (SP), onde foi identificado que 71,6\% das enfermeiras não participaram de nenhum evento científico na área, nos últimos dois anos (GARDENAL et al., 2002).

Quanto às práticas obstétricas investigadas junto aos profissionais sobre a sua realização ou não por eles, foi afirmada a realização de episiotomia, de parto gemelar e de 
apresentação pélvica, pelos entrevistados. O guia prático de assistência ao parto normal da OMS (1996) recomenda uma porcentagem de episiotomias de 10\%. O Integrated Management of Pregnancy and Childbirth (IMPAC), manual sobre o manejo das complicações da gravidez e parto da OMS, enfatiza que a episiotomia não deve ser realizada como procedimento de rotina, contudo ela deve ser considerada nos seguintes casos: parto vaginal complicado (apresentação pélvica, distócia de ombro e parto com fórceps), presença de cicatrizações de mutilações dos órgãos genitais femininos ou de lacerações de terceiro e quarto grau mal curados, e por fim em casos de sofrimento fetal (WHO, 2000).

A OMS recomenda ainda que os profissionais de saúde que assistem o parto devem ser capazes de realizar a episiotomia e a sutura desta, a episiorrafia, de modo adequado e devem receber treinamento específico para isto.

De acordo com as Portarias $n^{\circ}$ 2.815/98 e 163/98 do Ministério da Saúde e a Resolução do Conselho Federal de Enfermagem (COFEN) n 223/99 cabe à enfermeira obstétrica a identificação das distócias obstétricas e tomada de providências até a chegada do médico, devendo intervir, de conformidade com sua capacitação técnico-científica, adotando os procedimentos que entender imprescindíveis, para garantir a segurança da mãe e do filho; prestação da assistência à parturiente e ao parto normal; realização da episiotomia e episiorrafia com aplicação de anestesia local, quando necessário; acompanhamento do trabalho de parto; execução do parto sem distócia; e emissão do laudo de internação (ABENFO, 2002).

O parto normal com apresentação pélvica consiste numa distócia de apresentação. A morbimortalidade perinatal no parto com apresentação pélvica é de três a cinco vezes maior do que a do parto com apresentação cefálica (NEME, 1995). Os profissionais entrevistados que afirmaram realizar parto, com apresentação pélvica e de gemelar, ressaltaram ainda que realizam este procedimento na ausência do médico ou numa emergência. A assistência ao 
parto na gestação gemelar exige dos profissionais habilidades e competências para conduzir as possíveis complicações (NEME, 1995).

Nas Competências Essenciais para o Exercício Básico da Obstetrícia publicada pela Confederação Internacional de Parteiras (ICM), são preconizadas como habilidades básicas para os profissionais que prestam cuidados, durante o parto e nascimento, a realização da episiotomia e episiorrafia, se for necessário, contudo este documento preconiza como habilidades adicionais executar manobras apropriadas diante de um parto com apresentação pélvica e administrar ocitócicos adequadamente para estimular ou induzir o parto ou tratamento de hemorragias pós-parto. O documento deixa claro que as habilidades adicionais preconizadas dependerão da realidade de cada país, da legislação vigente, do preparo dos profissionais para a realização destes procedimentos e do meio ambiente adequado (INTERNATIONAL CONFEDERATION OF MIDWIVES, 2002).

Ressaltamos, ainda, que currículos adequados a cada realidade, fundamentados em evidências científicas, com enfoques baseados em competência para a aprendizagem e para a avaliação das habilidades bem como programas de educação continuada que promovam a atualização e ampliação das competências dos profissionais são estratégias que favorecem a promoção da atenção qualificada ao parto (MCDONALD; STARRS, 2003a). Da mesma forma, normas e protocolos assistenciais para guiar e respaldar a atenção de qualidade em obstetrícia, assim como ter um contexto facilitador, ou seja, possuir políticas, leis e regulamentos que respaldem as ações dos profissionais, e possuir infra-estrutura eficaz do sistema de saúde, incluindo equipamentos e insumos adequados e sistemas de referência, comunicação e transporte são requisitos indispensáveis para a garantia de atenção qualificada ao parto (MCDONALD; STARRS, 2003a).

Todos os profissionais que atuam na assistência ao parto, nas instituições de saúde estudadas, de alguma forma receberam algum tipo de treinamento, contudo, o reconhecimento 
de que alguém recebeu treinamento não implica que esteja necessariamente qualificado, uma vez que ser "treinado" não garante a aquisição de conhecimentos e habilidades. Por outro lado, ser "qualificado" implica no competente uso do conhecimento e na habilidade de prover cuidado obstétrico competente, durante a gravidez, parto e pós-parto (STARRS, 1998).

Um grande percentual dos profissionais estudados, 18 (72\%), recebeu treinamento informal para a assistência ao parto, ou seja, por meio de cursos de atualização, de acompanhamento prático por outros profissionais, o que não os habilita legalmente para exercer esta atividade. Contudo vale ressaltar que, mesmo sem uma qualificação adequada, muito destes profissionais, ao seu modo, ao longo dos anos têm prestado importante contribuição na assistência à mulher e a seu recém-nascido no município estudado.

Os dados do presente estudo revelam ainda uma falta de delimitação nos limites de atuação entre as diversas categorias profissionais de enfermagem, quando se constata que, independente do nível de qualificação formal do profissional de enfermagem no município estudado, todas as categorias profissionais, especialmente os técnicos e auxiliares de enfermagem, ainda realizam partos na sua prática profissional.

Da mesma forma, fica evidente que a definição de protocolos assistenciais, especialmente aqueles que deveriam nortear a tomada de decisão profissional quanto às práticas baseadas em evidências científicas, inexiste na realidade estudada. O manejo ativo do terceiro período do parto, a realização de partos obstruídos, de parto gemelar, o uso de partograma são exemplos de práticas que, na realidade estudada, ainda carecem de uma definição e sistematização sobre a quem cabe a sua realização, quando e por que realizá-las.

\subsection{As práticas obstétricas}

Os resultados da avaliação das competências da equipe de profissionais da área da 
saúde possuem um importante papel na definição de políticas de saúde, no desempenho organizacional, no gerenciamento de riscos à saúde, na avaliação da eficácia dos programas de treinamento e formação de profissional, na seleção de novos profissionais, na melhoria do desempenho individual e supervisão da atenção oferecida (KAK; BURKHALTER; COOPER, 2001).

O exercício da prática profissional exige dos profissionais de saúde o domínio de um grande número de competências para oferecer serviços de qualidade. A avaliação periódica de competências profissionais deve ser planejada para aquelas áreas que são consideradas de baixa freqüência, de alto risco ou críticas. Estudiosos vêm mostrando que as competências requeridas nestas áreas devem ser avaliadas para assegurar que os profissionais de saúde sejam capazes de desempenhar atividades raras, de alto risco e críticas (KAK; BURKHALTER; COOPER, 2001).

Um movimento internacional, em defesa da saúde materna, que tomou força em 1987 com a Iniciativa por uma Maternidade Segura, vem expondo as precárias condições de saúde de mães e bebês no mundo e especialmente em países em desenvolvimento, e, ao mesmo tempo, o movimento tem promovido um amplo debate e estímulo a revisões das práticas em obstetrícia, a fim de assegurar e proteger a saúde e a vida das mulheres e seus recém-nascidos.

O desafio que se coloca na assistência materna é a sua imprevisibilidade, pois complicações que colocam em risco a saúde e a vida de uma mulher e do seu filho podem surgir, e no momento do parto esta imprevisibilidade se associa à necessidade de medidas urgentes para remediar ou tratar o problema.

Nesse sentido, a classificação pela OMS, em 1996, das práticas que apresentam evidências científicas de boa conduta em obstetrícia e daquelas recomendadas, com cautela, como inadequadas ou prejudiciais tem trazido importante contribuição no estabelecimento de 
padrões de qualidade no cuidado obstétrico e neonatal.

Encontramos neste estudo, nas maternidades de Rio Branco, que algumas práticas são adotadas de acordo com as recomendações da OMS. A alimentação e hidratação são liberadas e estimuladas durante o trabalho de parto, existe o cuidado por parte do serviço de nutrição de oferecer alimentos líquidos nutritivos e calóricos.

A tricotomia e enema, práticas consideradas prejudiciais, não são realizadas de rotina nas instituições pesquisadas. Recomenda-se que estas práticas devem ser feitas somente se solicitadas pela mulher, porém esta escolha deve ser de forma consciente. A mulher deve receber orientações não tendenciosas durante o pré-natal para que possa tomar esta decisão (BRASIL. MS., 2001). No entanto, estas práticas ainda estão sendo utilizadas rotineiramente em instituições de saúde no Brasil (LOPES et al., 2001; REIS; PATRÍCIO, 2005).

Nas maternidades do Rio de Janeiro, o enema foi utilizado em 17\% dos partos normais de uma maternidade e 38\% na outra instituição, enquanto a tricotomia foi realizada em 52,3\% dos partos nestas instituições, sendo que mais de 45,9\% das mulheres que tiveram parto normal fizeram a tricotomia em casa, totalizando 98,2\% das mulheres (D’ORSI et al., 2005).

Um ensaio clínico realizado num hospital-escola investigou os efeitos do enteroclisma sobre a contaminação fecal, durante o trabalho de parto e parto, e constatou que a freqüência da contaminação fecal no primeiro e segundo períodos clínicos do parto não diferiu significativamente entre os dois grupos (com e sem enteroclisma), e também verificou que a utilização do enteroclisma não abreviou a duração do trabalho de parto e do período expulsivo, independente da paridade (LOPES et al., 2001).

O estímulo à deambulação, prática benéfica e recomendada durante o trabalho de parto de algumas parturientes, também foi observado neste estudo. As enfermeiras obstétricas foram os profissionais que mais estimularam esta prática, contudo a pequena área física do 
centro obstétrico não contribui para o estímulo e a concretização da mesma.

Alguns estudos indicam que a deambulação da mulher, durante o trabalho de parto, pode acelerar um trabalho de parto lento, principalmente nas primeiras horas da fase ativa, assim como diminuir a incidência de parto fórceps e de cesárea (GOER, 1999).

Estudo sobre os efeitos da deambulação no trabalho de parto de primigesta mostrou que a quantidade deambulada, especialmente durante as três primeiras horas da fase ativa do trabalho de parto, está associada ao encurtamento do trabalho de parto (MAMEDE, 2005).

Entre as práticas benéficas e que devem ser estimuladas, existem métodos não invasivos e não farmacológicos para alívio da dor que podem ser utilizados, durante o trabalho de parto, como o banho de imersão ou de chuveiro, massagens e toques. Encontramos neste estudo, embora em uma única situação, que apenas as enfermeiras obstétricas utilizaram a massagem como método não farmacológico de alívio da dor.

Nas instituições estudadas, a posição adotada para todas as parturientes durante o parto foi a posição litotômica. As instituições não oferecem a possibilidade da mulher parir em outra posição. Em duas maternidades do Rio de Janeiro, um estudo identificou que a posição de litotomia foi a posição adotada em 98,5\% dos partos vaginais (D’ORSI et al., 2005). Há algumas décadas tem surgido a preocupação sobre qual seria a melhor posição para o parto. Estudos sugerem que a posição verticalizada ou com inclinação lateral causa menos desconforto e dificuldade nos puxos, menos traumatismo vaginal ou perineal, reduz o tempo deste período, assim como a necessidade de partos assistidos, de episiotomias, e das alterações no BCF. Por outro lado, os resultados também mostram um aumento de lacerações de segundo grau e de perda sanguínea superior a 500 ml (OMS, 1996, GUPTA; HOFMEYR, 2006).

Um estudo randomizado controlado, realizado num centro de parto normal no 
Brasil, comparou as posições litotômica e lateral esquerda e constatou que na posição lateral houve uma redução significante do traumatismo perineal e de episiotomia (BASILE, 2001).

A OMS recomenda que a mulher deve ser estimulada a escolher a posição que for mais confortável e que suas escolhas devem ser respeitadas e apoiadas, para isso os profissionais de saúde devem estar aptos a manejar o parto em outras posições que não a supina, para não serem um fator de inibição na escolha das mulheres (OMS, 1996).

Identificamos, também, neste estudo que a presença de acompanhantes durante o trabalho de parto e parto não faz parte da rotina das instituições pesquisadas. Respeitar a escolha da mulher sobre seus acompanhantes, durante o trabalho de parto e parto, permitir e incentivar que isto aconteça em todas as instituições de saúde é a recomendação da OMS para a humanização do nascimento.

Estudos controlados sobre o assunto mostraram que as gestantes ficam mais seguras e confiantes durante o parto, quando são acompanhadas por alguém de sua confiança, resultando num encurtamento do trabalho de parto, um menor volume de medicações e analgesia peridural, menor número de cesáreas e menos escores de Apgar abaixo de sete (OMS, 1996; BRASIL. MS., 2001).

No Brasil, a Lei ${ }^{0}$ 11.108, de 7 de abril de 2005 garante o direito às parturientes da presença de acompanhante durante o trabalho de parto, parto e pós-parto imediato, no âmbito do SUS, e a Portaria ${ }^{\circ} 2.418$ de 2 de dezembro de 2005 do Ministério da Saúde vem regulamentar esta lei, garantindo este direito à toda gestante atendida no SUS com os custos de acomodações e refeições deste acompanhante pagos pelo Estado. A Portaria estabeleceu ainda o prazo de seis meses para que os hospitais adaptem suas instalações e procedimentos à nova regra (BRASIL. MS., 2005; BRASIL. PRESIDÊNCIA DA REPÚBLICA, 2005). No entanto, a presença do acompanhante ainda não é uma realidade em nosso país, e especialmente na realidade estudada, como constatamos nesta pesquisa. 
Uma investigação foi realizada, em 2004, sobre a oferta de serviços e ações na atenção às mulheres brasileiras atendidas no Sistema Único de Saúde. Esta pesquisa identificou que 65,3\% dos municípios brasileiros não permitem a presença de um acompanhante, no período de trabalho de parto e do parto (COSTA, 2004).

Um estudo recente no Brasil sobre esta temática, onde a pesquisadora mediu o nível de satisfação em vários procedimentos, antes, durante e após o parto, constatou que as mulheres acompanhadas tiveram um índice de satisfação cinco vezes maior em relação aos resultados apurados no grupo-controle. Em se tratando do pré-parto, o índice foi oito vezes maior, quando comparado com as mulheres que não tiveram acompanhantes (BRUGGEMANN, 2005).

Kak, BurKhalter e Cooper (2001) recomendam que, ao se propor a análise das competências profissionais, esta deve envolver comparação dos dados a um padrão de competência. A este respeito, a Confederação Internacional das Parteiras, apoiada pela OMS e pela FIGO, liderou o trabalho de elaboração e definição das competências essenciais para o desenvolvimento da atenção qualificada em obstetrícia (INTERNATIONAL CONFEDERATION OF MIDWIVES, 2002).

As competências essenciais estão definidas de acordo com o modelo de cuidado obstétrico que está baseado na premissa de que a gravidez e nascimento são eventos de vida normais. Este modelo de cuidado inclui a monitoração do bem-estar físico, psicológico, espiritual e social da mulher/família ao longo do ciclo reprodutivo; o fornecimento de educação individualizada à mulher, orientação e cuidado de pré-natal; assistência contínua durante o trabalho de parto, nascimento e no pós-parto imediato; a assistência contínua durante todo o período pós-natal; com o mínimo de intervenções tecnológicas. Inclui ainda a identificação e encaminhamento das mulheres que requerem atenção de especialista em obstetrícia ou outra especialidade. Este modelo de cuidado é, portanto, centrado na mulher e é 
a ela que ele deve prestar contas (INTERNATIONAL CONFEDERATION OF MIDWIVES, 2002).

Falar em competência de um profissional compreende falar sobre seus conhecimentos, habilidades, destrezas, características pessoais as quais influenciam na tomada de decisão, autocontrole e autoconfiança (KAK; BURKHALTER; COOPER, 2001).

Os resultados de nosso estudo revelam que, com relação às competências esperadas para fornecimento de um cuidado de alta qualidade e culturalmente sensível durante o parto e nascimento, muitas das habilidades básicas deixaram de ser desenvolvidas ou, quando realizadas, o foram de forma incompleta.

Identificamos neste estudo que a história específica, habilidade básica imprescindível na admissão da parturiente, foi realizada de forma incompleta pelos profissionais de enfermagem. A realização da anamnese completa, com levantamento e avaliação de dados e informações contidas no cartão de pré-natal, para identificar possíveis complicações no trabalho de parto e parto e assim planejar e realizar uma assistência individualizada a cada mulher é fundamental, mesmo para as gestações consideradas de baixo risco (BRASIL. MS., 2001). A ausência da história específica completa significa oportunidades perdidas para uma assistência qualificada às parturientes e a seus filhos.

A ausculta dos batimentos cardiofetais e o toque obstétrico são atividades fundamentais no acompanhamento da evolução do trabalho de parto. Neste estudo observamos estas atividades sendo realizadas de maneira incompleta, ou seja, não foram descritos a localização e o ritmo do BCF, só algumas anotações apresentaram a posição e descida fetal e nenhuma teve avaliação da bacia, quando foi realizado o toque vaginal. Na forma incompleta como foram realizados tanto a ausculta do BCF como o toque vaginal, perde-se a oportunidade de subsidiar informações relacionadas ao bem-estar materno-fetal e à condução do trabalho de parto. 
Está clara a relação entre o bem-estar fetal e a freqüência cardíaca. O sofrimento fetal pode se manifestar pela anormalidade na freqüência cardíaca (aumento ou diminuição), pela diminuição da variabilidade ou desaceleração (OMS, 1996).

Os profissionais de enfermagem devem possuir competências necessárias para executar atividades como ausculta do BCF, toque vaginal e amniotomia, com base nos padrões de assistência de boa qualidade preconizados. Não basta apenas realizar repetidas vezes uma tarefa nova para se tornar competente nela, é necessário ter educação pré-serviço e em serviço, receber treinamento com supervisão e ter seu desempenho avaliado continuamente (KAK; BURKHALTER; COOPER, 2001).

O partograma, a palpação abdominal e a avaliação vesical são habilidades básicas que não foram observados nas instituições pesquisadas. Recomendado pela OMS, o partograma é uma representação gráfica que deve ser utilizado para acompanhar a evolução do trabalho de parto, facilitando a avaliação e o manejo do mesmo. Com sua utilização é possível fazer diagnóstico precoce das distócias e suas respectivas intervenções (BRASIL. MS., 2001).

Além do gráfico que representa a dilatação cervical e a descida da apresentação com relação ao tempo, o partograma pode possuir espaço para anotações sobre freqüência das contrações, medicamentos, BCF e outros fatos importantes. É um recurso prático e uma forma eficiente de trocas de informações técnicas sobre o progresso do trabalho de parto entre equipes multiprofissionais. Um estudo realizado pela OMS sobre o uso do partograma identificou uma redução da incidência de trabalho de parto prolongado e redução nas taxas de cesáreas de emergência (ENKIN et al., 2005).

O não-uso do partograma pode dificultar a seqüência do atendimento na evolução do trabalho de parto da parturiente, bem como a integração das várias equipes de profissionais que acompanham esta mulher durante a sua permanência no pré-parto. 
Outra atividade que também não foi observada na rotina dos cuidados de enfermagem, neste estudo, foi a verificação da pressão arterial. Observamos que não foi realizada em todas as gestantes durante a admissão, não foi verificada de rotina durante o trabalho de parto e em apenas uma das 11 puérperas observadas, durante o pós-parto, foi verificada a pressão arterial. A pressão arterial é um importante sinal clínico das condições de saúde materna. Um estudo identificou que 57,7\% das indicações obstétricas para transferências de gestantes, parturientes ou puérperas (a maioria) para a unidade de terapia intensiva, num hospital terciário, foram os distúrbios hipertensivos induzidos pela gravidez (VIGGIANO et al., 2004). Portanto, é imprescindível o acompanhamento deste sinal clínico, durante todo o processo do nascimento.

A revisão da placenta e dos anexos não foi observada nos partos realizados pela enfermagem neste estudo. Esta é uma prática benéfica e que deve ser estimulada (OMS, 1996). O exame da placenta, cordão umbilical e membranas deve ser feito logo após a expulsão, principalmente para verificar a integridade dos mesmos e certificar que não foram deixados restos placentários ou de membranas na cavidade uterina (BRASIL. MS., 2001).

Os cuidados no pós-parto imediato foram observados apenas nos partos realizados pelas enfermeiras obstétricas, também foram elas as únicas profissionais de enfermagem que estimularam a amamentação na sala de parto, contudo o contato pele a pele do recém-nascido com a mãe não foi observado, verificamos apenas o contato entre mãe e filho na primeira meia hora de nascido.

A primeira hora após o nascimento é muito propícia para iniciar a amamentação, visto que o recém-nascido normalmente está bem alerta, com reflexo de sucção ativo, levando ao estímulo precoce da produção de ocitocina e prolactina, além de possibilitar a formação do vínculo mãe-filho (BRASIL. MS., 2001).

O quarto período clínico do parto (ou de Greenberg) é o período do pós-parto 
imediato, com duração considerada de uma hora para alguns autores e para outros de duas horas. É um período de grande risco materno, com possibilidade de grandes hemorragias (BRASIL. MS., 2001). A OMS (1996) recomenda que a mulher deve ser observada cuidadosamente durante as primeiras horas após o parto. As observações mais importantes incluem o volume da perda sanguínea, a contratilidade uterina, a altura do fundo uterino e avaliação da pressão arterial. A não-observância desses cuidados, identificados neste estudo, pode levar a mulher a grandes riscos, dificultando inclusive o diagnóstico precoce das intercorrências.

A dinâmica uterina, a avaliação da dilatação do colo e descida da apresentação são fundamentais no monitoramento da progressão do trabalho de parto (OMS, 1996). Neste estudo, observamos que o controle da dinâmica uterina foi uma habilidade que não fez parte da rotina das práticas obstétricas. Esta atividade foi realizada apenas pelos estudantes de enfermagem e esporadicamente pelas enfermeiras obstétricas. Esta situação diminui as informações com que a equipe de profissionais pode contar para a avaliação da progressão do trabalho de parto e posterior conduta.

A prática de fazer pressão no fundo do útero, durante o segundo período do trabalho de parto, conhecida como manobra de Kristeller, foi realizada pelos profissionais de enfermagem de nível médio e pelo médico nos partos realizados pela equipe de enfermagem. Esta manobra que tem a intenção de acelerar o nascimento é uma habilidade em que não existem evidências sobre a sua utilidade, que, além do aspecto do maior desconforto materno, ela pode trazer danos ao útero, ao períneo e ao feto (OMS, 1996). Um estudo identificou que a manobra de Kristeller foi realizada em 49,8\% dos partos realizados em duas maternidades do Rio de Janeiro (D’ORSI et al., 2005).

Quanto ao uso de ocitócicos, observamos neste estudo que, durante o trabalho de parto, esta medicação foi prescrita apenas pelo médico, coube aos profissionais de 
enfermagem realizarem sua administração, contudo, no momento do parto observamos que os profissionais de enfermagem de nível médio realizaram a indicação e administração desta medicação. Para a OMS (1996), não está claro que o uso liberal da correção da dinâmica uterina com ocitocina ofereça benefícios para as mulheres e seus recém-nascidos, o seu uso só deve ser considerado em instituições onde houver o acesso imediato à cesariana, caso ela seja necessária. Portanto, a correção de dinâmica com ocitocina é uma intervenção importante e somente deve ser usada com uma indicação válida.

O uso rotineiro da episiotomia é uma prática freqüentemente utilizada de modo inadequado (OMS, 1996). Dos 11 partos normais realizados pela enfermagem neste estudo, em 10 foi realizada a episiotomia. Não existem evidências em favor da utilização rotineira da episiotomia. Os estudos mostram que o uso restrito da episiotomia apresenta um número maior de benefícios para a mulher, incluindo menos trauma perineal posterior e menos complicações (CARROLLI; BELIZAN, 2006).

A OMS (1996) recomenda que, em determinadas situações, como sofrimento fetal, progressão insuficiente do parto e ameaça de laceração de terceiro grau podem ser bons motivos para a indicação da episiotomia.

Durante os primeiros 50 anos do século XX, os índices de episiotomia aumentaram de maneira substancial, junto com a tendência dos partos hospitalares. A episiotomia se tornou um dos procedimentos cirúrgicos mais realizados no mundo (CARROLLI; BELIZAN, 2006).

Um estudo realizado num centro de parto normal no Brasil identificou que em 26,5\% dos partos normais ocorreu a episiotomia, sendo que, quando analisada a paridade das mulheres, a episiotomia foi praticada em 43,3\% das nulíparas e 15,9\% das multíparas (SCHNECK, 2004).

Uma investigação feita num hospital universitário de São Paulo identificou que a 
episiotomia foi realizada em $76,2 \%$ dos partos e que, entre as primigestas, $95,2 \%$ delas foram submetidas a esta intervenção (OLIVEIRA; MIQUILINI, 2005).

O manejo ativo do terceiro período do parto, com administração de ocitocina, pinçamento e corte precoce do cordão e tração controlada do mesmo, é uma recomendação da FIGO/ICM para reduzir os índices de hemorragia pós-parto devido à atonia uterina (INTERNATIONAL CONFEDERATION OF MIDWIVES, 2002).

Uma revisão sistemática que incluiu cinco estudos clínicos aleatórios onde foram comparadas as condutas ativa e expectante, no terceiro período do parto, concluiu que a conduta ativa sistemática é a melhor opção quanto à perda sanguínea, hemorragia puerperal e outras complicações graves deste período. No entanto, os revisores recomendam que pelos riscos secundários que a conduta ativa pode trazer, como náuseas, vômitos e hipertensão, ela seja adotada de rotina apenas para as mulheres cujo parto se realize por via vaginal e em uma instituição de saúde, não recomendando nos partos domiciliares (PRENDIVILLE; ELBOURNE; MCDONALD, 2006).

Neste estudo encontramos que o manejo ativo foi realizado apenas pelos profissionais de enfermagem de nível médio de ensino. As enfermeiras obstétricas utilizaram o manejo fisiológico, isto pode ter ocorrido pelo fato de a recomendação do manejo ativo ser recente e a formação das especialistas no Estado do Acre não adotarem esta conduta.

Os achados do presente estudo permitiram-nos identificar que o modelo de atenção ao parto no município de Rio Branco assemelha-se ao modelo definido por Pettersson e Stone (2004), de serviços de atenção à saúde materna no Brasil. De acordo com as autoras, o modelo brasileiro se enquadra entre aquele de países onde a atenção obstétrica é quase que eminentemente institucionalizada, com limitada ação dos profissionais não médicos. Segundo dados tomados dos indicadores básicos de saúde das Américas, 80\% dos partos no Brasil são realizados por médicos e os restantes ficam por conta dos não médicos (PETTERSSON; 
STONE, 2004).

Segundo as autoras, tais modelos de atenção obstétrica, dominados pelos médicos, são caracterizados por índices extremamente altos de parto cesárea. Referem, ainda, que pesquisas têm mostrado que esta intervenção está associada com maiores taxas de mortes entre as mulheres no parto, as quais não estão associadas a partos complicados.

Conforme estatísticas das instituições estudadas, o percentual de partos operatórios, realizados no primeiro semestre de 2005 (43\%), superou a expectativa da OMS.

A identificação de características deste modelo, definido por Pettersson e Stone (2004), de atenção obstétrica se fez presente em nosso estudo, especialmente na forma como a divisão do trabalho entre os membros da equipe de profissionais se configura em cada uma das instituições estudadas.

Os testes estatísticos revelaram que as instituições estudadas apresentam modelos diferenciados quanto a quem cabe a responsabilidade de execução de determinadas competências na atenção à parturiente.

O desempenho de competências que exigem habilidades de maior complexidade, como ausculta do BCF, toque vaginal, diagnóstico de trabalho de parto, durante a admissão da parturiente (Tabela 10), fica a cargo do pessoal de enfermagem de nível médio na instituição em que não há a presença da enfermeira obstétrica. E em contrapartida na instituição onde esta profissional está presente, estas atividades são exclusivamente realizadas pelos médicos na admissão da parturiente.

Da mesma forma, nas instituições estudadas, o controle do BCF, toque vaginal e amniotomia no acompanhamento do trabalho de parto, conforme Tabela 12, se fazem diferentemente. Na instituição onde não há enfermeira obstétrica, tais procedimentos são delegados aos profissionais de enfermagem de nível médio. Esta constatação é desencorajante, uma vez que cada uma dessas habilidades representa uma competência 
necessária para combater uma proporção significante de emergências obstétricas. Por outro lado, na instituição em que a enfermeira obstétrica atua diretamente no centro obstétrico, são os médicos que desempenham a maior parte desses procedimentos.

No que se refere à realização do parto normal, as maternidades estudadas mostram também diferenças significantes nos modelos de divisão de trabalho, conforme Tabela 13.

Na maternidade onde não há a presença da enfermeira obstétrica são os profissionais de enfermagem de nível médio que realizaram $90 \%$ dos partos, enquanto na outra maternidade foram os médicos que realizaram a grande maioria dos partos, $71,43 \%$ contra os $28,57 \%$ das enfermeiras obstétricas.

Diante de tais observações, os nossos achados indicam que o modelo de atenção materna, nas instituições estudadas, não prioriza a qualificação profissional para a assistência à mulher no trabalho de parto e parto. Estas evidências nos possibilitam verificar que contradições podem estar presentes no interior da realidade estudada.

A forma como a organização do trabalho se estabelece em cada instituição estudada parece estar muito mais relacionada com a categoria profissional do que com a própria qualificação e desempenho profissional.

Os testes estatísticos revelaram que há diferenças institucionais no desenvolvimento de habilidades de maior complexidade na assistência à parturiente, desde a internação até a resolução do parto.

A presença da enfermeira obstétrica parece ser o marcador para o tipo de modelo de divisão de trabalho usado, ou seja, a quem cabe a responsabilidade do desempenho de tais habilidades. E o mais interessante e intrigante nos achados deste trabalho é que quando esta profissional não participa do quadro funcional da instituição, as habilidades obstétricas de maior complexidade podem e são delegadas ao pessoal de enfermagem de nível médio. E, quando há um vínculo funcional institucional da enfermeira obstétrica diretamente na 
assistência em centro obstétrico, fica a cargo do médico grande parte das habilidades de maior complexidade para o seu desempenho.

Esta constatação pode significar a necessidade de demarcação e apropriação, consciente ou não, de um espaço não institucionalizado, historicamente ocupado pelas parteiras, para outro hegemônico em que o médico sempre deteve o domínio - o hospital.

Portanto, parece que a lógica do modelo de divisão do trabalho na atenção ao parto, nas instituições estudadas, se constrói muito mais nas posições hierárquicas dos profissionais do que nas competências profissionais. 
Limitações e Conclusões 


\section{LIMITAÇÕES E CONCLUSÕES}

Os resultados deste estudo apresentam limitações quanto à avaliação de competências, dado que não foi nosso interesse avaliar o desempenho dos profissionais sobre as competências essenciais em obstetrícia, mas sim identificar se as ações relacionadas àquelas competências eram desenvolvidas no atendimento às parturientes, durante o processo de parturição.

No entanto, as entrevistas dos profissionais e a observação sistemática no local de trabalho dos mesmos nos possibilitaram tirar importantes conclusões:

A equipe de enfermagem que atende a mulher no processo do parto e nascimento em Rio Branco é composta de enfermeiras obstétricas, técnicas e auxiliares de enfermagem;

O perfil dos profissionais de enfermagem constitui-se: predominantemente do sexo feminino, idade média em torno de 41 anos, metade deles é casado ou possui parceria fixa, a maioria possui mais de 10 anos de formação profissional, a carga horária semanal trabalhada, 63 horas, encontra-se acima da média encontrada no Brasil, existe diferença na remuneração salarial entre as maternidades, $40 \%$ deles trabalham em mais de uma instituição, os profissionais de nível médio possuem maior tempo de experiência na área (170 meses) do que as enfermeiras obstétricas (80 meses), as enfermeiras obstétricas foram a categoria profissional que mais buscou aprimoramento profissional;

Quase 84\% (25) dos profissionais de enfermagem foram treinados e/ou capacitados para realizarem parto;

72\% (18) dos profissionais receberam educação informal para a assistência ao 
parto, enquanto apenas $28 \%$ (7) dos profissionais da equipe de enfermagem que realiza parto nas instituições de Rio Branco são considerados qualificados para este atendimento, de acordo com os critérios e requisitos estabelecidos pela Organização Mundial de Saúde e pela Confederação Internacional das Parteiras;

A realização do parto normal nas maternidades de Rio Branco é feita por pessoal de enfermagem de nível médio, enfermeira obstétrica e pelo médico; Algumas práticas obstétricas recomendadas pela OMS são adotadas pelas maternidades;

Muitas das competências essenciais para o atendimento ao trabalho de parto e parto não são desenvolvidas ou são realizadas de forma incompleta;

A utilização de práticas baseadas em evidências científicas atualizadas necessita ser incentivada;

Inexiste a prática do uso de partograma nas instituições estudadas;

O modelo de atenção materna, nas instituições estudadas, não prioriza a qualificação profissional, a organização do trabalho parece estar mais relacionada com a categoria profissional do que com a qualificação e desempenho profissional. 
Implicações para o Ensino, Pesquisa e Assistência 


\section{IMPLICAÇÕES PARA O ENSINO, PESQUISA E ASSISTÊNCIA}

Os resultados da avaliação sobre as competências clínicas em atenção ao trabalho de parto e parto poderão ser úteis para o início da discussão e reflexão sobre o estabelecimento de protocolos assistenciais para a atenção materna baseada nas melhores práticas e competências essenciais em obstetrícia, na realidade de Rio Branco.

O treinamento e padronização de um nível mínimo e essencial de competências em obstetrícia poderão ser estratégias para melhorar o desempenho dos profissionais que assistem no trabalho de parto e parto.

Os resultados do estudo evidenciam que a realidade estudada carece de pessoal qualificado para o atendimento no processo de parturição, e que a formação de enfermeiras obstétricas deve ser estimulada como também a inserção das egressas destes cursos nas instituições e serviços de atenção à saúde materna.

No futuro, a realização de outros estudos que associem os resultados quantitativos desta pesquisa com outros mais qualitativos que busquem melhor compreender o ambiente de trabalho dos profissionais, focalizando os passos necessários para aumentar a demanda de pessoal qualificado em obstetrícia e diminuição de conflitos no compartilhamento da organização do processo de trabalho na realidade local, como também ao nível regional, poderá ser uma importante contribuição para o alcance da maternidade segura em nosso país. 
Referências Bibliográficas 


\section{REFERÊNCIAS BIBLIOGRÁFICAS}

ABENFO. Associação Brasileira de Obstetrizes e Enfermeiros Obstetras - seção São Paulo. Dispositivos legais relacionados à saúde da mulher e do recém-nascido: manual. São Paulo: ABENFO-SP, 2002.

ACRE. GOVERNO DO ESTADO DO ACRE. Nosso Acre. 2002. Disponível em: $<$ http://www.ac.gov.br/nossoacre.html>. Acesso em: 25 ago. 2003.

ACRE. GOVERNO DO ESTADO DO ACRE. Secretaria de Estado de Saúde. Plano Estadual de Saúde 2004-2007. Rio Branco, 2004.

ACRE. GOVERNO DO ESTADO DO ACRE. Secretaria Estadual de Saúde. 2006. Disponível em: <http://www.ac.gov.br.>. Acesso em: 03 mai. 2006.

AVERY, M. D. The evolution of the core competencies for basic midwifery pratice. $J$. Midwifery Women's Health, New York, v. 45, n. 6, p. 532-36, Nov.-Dec. 2000.

BASILE, A. L. O. Estudo randomizado controlado entre as posições do parto: litotômica e lateral esquerda. 2001. 105 f. Dissertação (Mestrado em Enfermagem) - Enfermagem, Universidade Federal de São Paulo, São Paulo, 2001.

BRASIL. Ministério da Saúde. Programa de Humanização do Pré-Natal e Nascimento. Brasília: MS, 2000.

BRASIL. Ministério da Saúde. Secretaria de Políticas de Saúde. Área Técnica de Saúde da Mulher. Parto, aborto e puerpério: assistência humanizada à mulher. Brasília: Ministério da Saúde, 2001.

BRASIL. Ministério da Saúde. Manual dos comitês de mortalidade materna. Brasília: MS, 2002.

BRASIL. Ministério da Saúde. Pacto nacional pela redução da mortalidade materna e neonatal. Informe da Atenção Básica, Brasília, ano 5, mai-jun. 2004a.

BRASIL. Ministério da Saúde. Indicadores e Dados Básicos para a Saúde. 2004b. Disponível em: <http://www.portal.saude.gov.br/portal/saude/ripsa>. Acesso em: 21 abr. 2006. 
BRASIL. Ministério da Saúde. Portaria. 2005. Disponível em:

<http://www.saude.gov.br/sas/PORTARIAS>. Acesso em: 23 mai. 2006.

BRASIL. Presidência da República. Casa Civil. Subchefia para assuntos jurídicos. 2005. Disponível em: <http://www.planalto.gov.br/ccivil>. Acesso em: 23 mai. 2006.

BRUGGEMANN, O. M. O apoio à mulher no nascimento por acompanhante de sua escolha: abordagem quantitativa e qualitativa. 2005. $180 \mathrm{f}$. Tese (Tese de Doutorado) Faculdade de Ciências Médicas, Universidade Estadual de Campinas, Campinas, 2005.

CARROLI, G.; BELIZAN, J. Episiotomy for vaginal birth (Cochrane Review). In: The Cochrane Library, Issue 1, 2006. Oxford: Update Software

COSTA, A. M. Atenção integral à saúde das mulheres: QUO VADIS? Uma avaliação da integralidade na atenção à saúde das mulheres no Brasil. 2004. 196 f. Tese (Doutorado em Ciências da Saúde) - Faculdade de Ciências da Saúde, Universidade de Brasília, Brasília, 2004.

D’ORSI, E. et al. Qualidade da atenção ao parto em maternidades do Rio de Janeiro. Rev. Saúde Pública, São Paulo, v. 39, n. 4, p. 646-54, ago. 2005.

ENKIN, M. et al. Guia para atenção efetiva na gravidez e no parto. Rio de Janeiro: Guanabara Koogan, 2005.

FAKO, T. T.; FORCHEH, N., NCUBE, E. Prospects of safe motherhood in Botswana: midwifery training and nurses' ability to complete the Botswana obstetric record. Soc. Sci. Méd., Oxford, v. 58, n. 6, p. 1109-20, Mar. 2004.

FEBRASGO. Federação Brasileira de Ginecologia e Obstetrícia. Oito passos para a maternidade segura: guia básico para serviços de saúde. Brasília: FEBRASGO/COMIN/OPAS/OMS/UNICEF/FNUAP, 1995.

FURLLERTON, J. et al. The International Confederation of Midwives' study of essential competencies of midwifery pratice. Midwifery, Edimburgo, v. 19, n. 3, p. 174-90, Sep. 2003.

GARDENAL, C. L. C. et al. Perfil das enfermeiras que atuam na assistência à gestante, parturiente e puérpera, em instituições de Sorocaba/SP (1999). Rev. Latino-am. Enfermagem, Ribeirão Preto, v. 10, n. 4, p. 478-84, jul.-ago. 2002. 
GIRARDI, S. N.; CARVALHO, C. L. Mercado de trabalho e regulação das profissões de saúde. In: NEGRI, B.; FARIA, R.; VIANA, A. L. D’A. (Org.) Recursos humanos em saúde: política, desenvolvimento e mercado de trabalho. Campinas: Unicamp, 2002. Cap. 3.2, p. 221-56.

GOER, H. Does walking enhance labor progress? Birth, Berkeley, v. 26, n. 2, p. 127-9, June 1999.

GOMES, F. A.; MAMEDE, M. V.; COSTA-JUNIOR, M. L. Mortes maternas mascaradas. In: BESSA, L. F.; CUNHA, M. A.; FERREIRA, T. F. (Org.). Saúde da mulher: desafios a vencer. Rio Branco: EDUFAC, 2004.

GUPTA, J. K.; HOFMEYR, G. J. Position in the second stage of labour for women. (Cochrane Review). In: The Cochrane Library, Issue 1, 2006.

HAGER, P.; GONCZI, A.; ATHANASOU, J. Topicos generales sobre la evaluación de la competência. Asses Evaluation Higher Educ., Sidney, v. 19, p. 327-39, junio 1994.

HARVEY, S. A. et al. Skilled birth attendant competence: an initial assessment in four countries, and implications for the Safe Motherhood movement. Int. J. Gynecol. Obst., Limerick, v. 87, n. 2, p. 203-10, Nov. 2004.

INSTITUTO BRASILEIRO DE GEOGRAFIA E ESTATÍSTICA. IBGE. Censo demográfico 2000. Disponível em: <http://www.ibge.gov.br>. Acesso em: 24 ago. 2005.

INSTITUTO BRASILEIRO DE GEOGRAFIA E ESTATÍSTICA. IBGE.Cidades@. 2002. Disponível em: http://www.ibge.gov.br/cidadesat. Acesso em: 24 mai. 2005.

INSTITUTO BRASILEIRO DE GEOGRAFIA E ESTATÍSTICA. IBGE. Pesquisa nacional por amostra de domicílio: síntese de indicadores 2002. Rio de Janeiro: IBGE, 2003.

INSTITUTO BRASILEIRO DE GEOGRAFIA E ESTATÍSTICA. IBGE. Pesquisa nacional por amostra de domicílio: síntese de indicadores sociais 2004. Rio de Janeiro: IBGE, 2005.

INTERNATIONAL CONFEDERATION OF MIDWIVES. Competencies. New York: ICM, 2002. Disponível em: <http://www.internationalmidwives.org>. Acesso em: 20 set. 2004.

KAK, N.; BURKHALTER, B.; COOPER, M. A. Measuring the competence of healthcare providers. Operations Res. Issue Paper, Bethesda, v. 2, n. 1, p. 1-28, July 2001. Disponível em: <http://www.qaproject.org/pubs/PDF/competence.pdf >. Acesso em: 10 abr. 2006. 
LAURENTI, R.; JORGE, M. H. P. M.; GOTLIEB, S. L. D. A mortalidade materna nas capitais brasileiras: algumas características e estimativas de um fator de ajuste. Rev. Bras. Epidemiol., São Paulo, v. 7, n. 4, p. 449-60, dez. 2004.

LOPES, A. C. Competências na organização curricular da reforma do ensino médio. Bol. Técnico do SENAC, Rio de Janeiro, v. 27, n. 3, set./dez. 2001.

LOPES, M. H. B. M. et al. O uso do enteroclisma no preparo para o parto: análise de suas vantagens e desvantagens. Rev. Latino-am Enfermagem, Ribeirão Preto, v. 9, n. 6, p. 49-55, nov.-dez. 2001.

MACDONALD, M.; STARRS, A. La atención calificada durante el parto. Un cuaderno informativo para salvar la vida de las mujeres y mejorar la salud de los recén nacidos. New York: Family Care Internacional, 2003a.

MACDONALD, M.; STARRS, A. La atencion calificada durante el parto. Recomendaciones para politica. New York: Family Care Internacional, 2003b.

MACLEAN, G. D. The challenge of preparing and enabling 'skilled attendants' to promote safer childbirth. Midwifery, Edinburg, v. 19, n. 3, p. 163-9, Sep. 2003.

MAMEDE, F. V. O efeito da deambulação na fase ativa do trabalho de parto. 2005. $100 \mathrm{f}$. Tese (Doutorado em Enfermagem) - Escola de Enfermagem de Ribeirão Preto, Universidade de São Paulo, Ribeirão Preto, 2005.

MINAYO, M. C. S.; SANCHES, O. Quantitativo-qualitativo: oposição ou complementaridade? Cad. Saúde Pública, Rio de Janeiro, v. 9, n. 3, p. 239-62, jul.-set. 1993.

NEME, B. Distócia fetal. In: NEME, B. Obstetrícia básica. São Paulo: Sarvier, 1995. Cap. 75, p. 508-37.

OLIVEIRA, S. M. J. V.; MIQUILINI, E. C. Freqüência e critérios para indicar a episiotomia. Rev. Esc. Enfermagem USP, São Paulo, v. 39, n. 3, p. 288-95, jul./ago./set. 2005.

ONOFRE, I. et al. A participação do enfermeiro assistencial nos cursos de pós-graduação. Enf. Cient., São Paulo, v.10, n. 2, p. 17-22, 1990.

ORGANIZAÇÃO MUNDIAL DE SAÚDE. OMS. Maternidade segura. Assistência ao parto normal: um guia prático. Genebra: OMS, 1996. 
ORGANIZAÇÃO PAN-AMERICANA DE SAÚDE. OPAS. 26ª Conferência Sanitária Panamericana. Washington: OPAS, 2002.

ORGANIZAÇÃO PAN-AMERICANA DE SAÚDE. OPAS. Perfil dos serviços de obstetrícia/parteria nas Américas. Washington: OPAS, 2004.

PAN AMERICAN HEALTH ORGANIZATION. PAHO. Overview of the nursing workforce in Latin America. Washington: PAHO/WHO/ICN, 2005. Disponível em: <http:/www.icn.ch/ global/Issue6LatinAmericaSP.pdf>. Acesso em: 20 maio 2006.

PERRENOUD, P. Dez novas competências para ensinar. Porto Alegre: Artes Médicas Sul, 2000 .

PERRENOUD, P. Ensinar: agir na urgência, decidir na incerteza. Porto Alegre: Artes Médicas Sul, 2001.

PETTERSSON, K. O.; STONE, K. Profiling midwifery services in the Americas models of childbirth care - a literature review. Washington: PAHO/WHO, 2004.

POLIT, D. F.; BECK, C.T.; HUNGLER, B.P. Fundamentos de Pesquisa em Enfermagem: métodos, avaliação e utilização. 5. ed. Porto Alegre: Artmed, 2004.

PRENDIVILLE, W. J.; ELBOURNE, D.; MCDONALD, S. Active versus expectant management in the third stage labour. (Cochrane Review). In: The Cochrane Library, Issue 1, 2006. Oxford: Update Software

REDE FEMINISTA DE SAÚDE. Comitê de prevenção de mortalidade materna. São Paulo: Rede Feminista de Saúde, 2003.

REIS, A. E.; PATRÍCIO, Z. M. Aplicação das ações preconizadas pelo Ministério da Saúde para o parto humanizado em um hospital de Santa Catarina. Ci. \& Saúde Coletiva, Rio de Janeiro, v.10, supl., p. 221-30, set.-dez. 2005.

RICHARDSON, R. J. et al. Pesquisa social: métodos e técnicas. São Paulo: Atlas, 1999. SAFE MOTHERHOOD. The safe motherhood initiative. New York: Family Care International, 1998. Disponível em: <http://www.safemotherhood.org>. Acesso em: 11 abr. 2005. 
SCHIRMER, J. Panorama dos cursos de especialização financiados pelo Ministério da Saúde. 2004. Conferência realizada no $15^{\circ}$ International Congress on Women's Health Issues, São Pedro, 2004.

SCHNECK, C. A. Intervenções obstétricas no centro de parto normal do Hospital Geral de Itapecerica da Serra Seconci-OSS: estudo descritivo. 2004. 105 f. Dissertação (Mestrado em Enfermagem) - Escola de Enfermagem, Universidade de São Paulo, São Paulo, 2004.

SEIAM. Sistema Estadual de Informações Ambientais. Rio Branco. 2002. Disponível em: $<$ http://www.seiam.ac.gov.br/rbranco.php>. Acesso em: 25 ago. 2003.

SISPACTO. Pacto de Indicadores da Atenção Básica. 2005. Disponível em: <http://www. saude.gov.br/pacto> . Acesso em: 12 set. 2005.

STARRS, A. The safe motherhood action agenda: priorities for the next decade. New York: Family Care Internacional, 1998.

TYRRELL, M. A. R.; SANTOS, R. S. Enfermagem obstétrica: transpondo os limites da enfermagem e da saúde reprodutiva. In: SEMINÁRIO ESTADUAL SOBRE O ENSINO DE ENFERMAGEM PARA A ASSISTÊNCIA AO NASCIMENTO E PARTO, 3., 2001, São Paulo. Anais... São Paulo: Departamento de Enfermagem Materno-Infantil e Psiquiátrica da EEUSP, 2001. p.13-30.

TRIVIÑOS, A. N. S. Introdução à pesquisa em ciências sociais: a pesquisa qualitativa em educação. São Paulo: Atlas, 1987.

URBANO, L. A. As reformulações na saúde e o novo perfil de profissional requerido. Rev. Enfermagem da UERJ, Rio de Janeiro, v. 10, n. 2, p. 142-5, maio-ago. 2002.

VIGGIANO, M. B. et al. Necessidades de cuidados intensivos em maternidade pública terciária. Rev. Bras. Ginecol. Obstet., Rio de Janeiro, v. 26, n. 4, p. 317-23, mai. 2004.

WORLD HEALTH ORGANIZATION. WHO. Coverage of maternity care: a listining of avaliable information. Geneva: WHO, 1996.

WORLD HEALTH ORGANIZATION. WHO. Reduction of maternal mortality: a joint WHO/UNFPA/UNICEF/World Bank statement. Geneva: WHO, 1999.

WORLD HEALTH ORGANIZATION. WHO. IMPAC - Mannaging complications in pregnancy and childbirth: a guide for midwives and doctors. Geneva:

WHO/UNFPA/UNICEF/World Bank, 2000. 
WORLD HEALTH ORGANIZATION. WHO. Maternal mortality in 2000: estimates developed by WHO,UNICEF and UNFPA. Geneva: WHO, 2003.

WORLD HEALTH ORGANIZATION. WHO. Beyond the numbers: reviewing maternal deaths and complications to make pregnancy safer. Geneva: WHO, 2004a.

WORLD HEALTH ORGANIZATION. WHO. Making pregnancy safer: the critical role of the skilled attendant: a joint statement by WHO, ICM, and FIGO. Geneva: WHO, 2004b.

WORTH-BUTLER, M.; MURPHY, R. J. L.; FRASER, D. M. Towards an integrated model of competence in midwifery. Midwifery, Edinburg, v. 10, n. 4, p. 225-31, Dec. 1994. 
Apêndices 


\section{APÊNDICE A - Termo de Consentimento Livre e Esclarecido (profissionais de saúde)}

Meu nome é Leila Maria Geromel Dotto, sou aluna do Programa de Pós-Graduação Doutorado, da Escola de Enfermagem de Ribeirão Preto - USP, área de concentração: Saúde Pública. Estou desenvolvendo uma pesquisa intitulada: Atenção qualificada ao parto: a realidade da assistência de enfermagem em Rio Branco-AC, para obtenção do título de Doutor em Enfermagem.

Este estudo tem por finalidade conhecer a realidade do atendimento ao trabalho de parto e parto nas maternidades do município de Rio Branco-AC, com especial enfoque no pessoal de enfermagem. Para isto, gostaria de entrevistá-la (o) e observar as ações/intervenções que você desenvolve com as parturientes. Você não será identificada (o) em momento algum da pesquisa e poderá a qualquer momento deixar de participar da mesma. Não haverá ônus para qualquer uma das partes envolvidas.

Esclareço que sua participação será muito importante para que possamos conhecer quem são os profissionais que trabalham na assistência ao parto nas maternidades de Rio Branco, e quais as atividades que realizam.

Agradeço sua colaboração, coloco-me à disposição para os esclarecimentos que se fizerem necessários, pelo telefone (68) 3223-7778 ou e-mail: leiladotto@uol.com.br.

Obrigada.

Leila Maria Geromel Dotto

Após ter lido e compreendido as informações acima, concordo em participar desta pesquisa e autorizo a utilização dos dados para o presente estudo que poderá ser publicado e utilizado em eventos científicos. 


\section{APÊNDICE B - Roteiro de Entrevista}

Número:

\section{I- IDENTIFICAÇÃO}

1- Sexo: ( ) feminino （） masculino 2-Idade: anos

3- Estado conjugal: ( ) solteiro(a) （ ) casado(a) （ ) separado(a) （ ) mora junto ( ) divorciado(a) ( ) viúvo(a)

4- Número de filhos: 5- Idade dos filhos:

6- Renda Familiar: $\mathbf{R} \$$ 7- Remuneração nesta instituição: $\mathbf{R}$ \$

\section{II- FORMAÇÃO E ATIVIDADE PROFISSIONAL}

8- Nível de instrução:

( ) ensino fundamental incompleto

( )ensino médio completo

( ) ensino fundamental completo

( )ensino superior incompleto

( ) ensino médio incompleto

( )ensino superior completo

9- Formação profissional: 10- Ano que concluiu:

\section{1- Formação:}

Básica (anos de estudo):

Profissional: Auxiliar/Técnico/Graduação/Especialização (local, o que aprendeu de obstetrícia: como? (aulas teóricas, práticas, estágios) quanto tempo? Carga horária total? Quem eram os professores? Aprendeu a fazer partos? Com quem? Havia supervisão? 
11- Fez curso de pós-graduação: ( ) Sim ( ) Não

( ) Especialização (mínimo 360 horas)

Nome: ( ) Concluído. Ano

Financiado pelo Ministério da Saúde ( ) Sim ( ) Não Carga horária:

( ) Em andamento

Nome: ( ) Concluído. Ano

Financiado pelo Ministério da Saúde ( ) Sim ( ) Não Carga horária:

( ) Em andamento

Nome: ( ) Concluído. Ano

Financiado pelo Ministério da Saúde ( ) Sim ( ) Não Carga horária:

( ) Em andamento

( ) Mestrado Nome: ( ) Concluído. Ano

( ) Em andamento

( ) Doutorado Nome: ( ) Concluído. Ano

( ) Em andamento

12- Realizou curso(s)/treinamento(s) de atualização/aprimoramento na área de assistência ao parto depois de sua formação profissional (últimos anos)?

( ) Sim ( ) Não

Nome: Carga horária: Ano:

Nome: Carga horária: Ano:

Nome: Carga horária: Ano:

Nome: Carga horária: Ano:

Nome: Carga horária: Ano:

13- Tem participado de eventos científicos (área de saúde da mulher) após a sua formação profissional? （） Sim （ ） Não

Nome: Ano:

Nome: Ano:

Nome: Ano: 
14- Tem mais de 01(um) emprego?( ) Sim Quantos? Quais? 1)

2) 3)

( ) Não

15- Jornada diária de trabalho:

16- Há quanto tempo trabalha na assistência ao parto?

16.1- Experiência em sala de parto (local/período):

17- Qual é a sua função nesta assistência:

18- Realiza o parto nesta maternidade? （ ） Sim ( ) Não

Se a resposta for SIM fazer as perguntas a seguir:

19- Realiza parto de gemelar? ( ) Sim ( ) Não

20- Realiza episiotomia? ( ) Sim ( ) Não

21- Realiza episiorrafia? ( ) Sim ( ) Não

22- Realiza parto de apresentação pélvica (nádegas)? ( ) Sim ( ) Não

23- Indica administração de ocitócico em que momento?

( ) nunca - Justifique:

( ) durante o trabalho de parto - Justifique:

( ) no momento da expulsão do feto - Justifique:

( ) após a saída da placenta - Justifique: 


\section{APÊNDICE C - Roteiro de Observação}

Número:

I- ADMISSÃO

Gesta Para

Apresentação fetal:

Motivo:

Idade Pré-natal: ( ) Sim ( ) Não Número de consultas:

Profissional que admitiu: Prof. Resp. AIH:

Anamnese( ) Algumas perguntas( ) Exame físico( ) Palpação( ) Dinâmica uterina( ) Ausculta( ) Toque( ) PA ( ) Tricotomia( ) Enema( ) Encaminhou para banho( )

Ofereceu camisola( ) Presença de acompanhante( )

Obs:

\section{II- TRABALHO DE PARTO}

1- Oferece líquidos (alimentação):( )Sim ( )Não Obs.

2- Métodos não invasivos e não farmacológicos de alívio da dor:

a) massagem: ( ) Sim ( ) Não Obs.

b) técnicas de relaxamento: ( ) Sim ( ) Não Obs.

3- Uso de partograma: ( ) Sim Em que momento inicia: ( ) Não

4- Estímulo à deambulação: ( ) Sim ( ) Não

5- Presença de um acompanhante: ( ) Sim O que faz: ( ) Não

\section{6- Identificação de sofrimento fetal:}

Profissional: Em que momento:

Ações/intervenções:

\section{7- Amniotomia:}

( ) Sim Profissional: Em que momento: ( ) Não

8- Uso de fármacos para controle da dor:

( ) Sim Qual? Em que momento: ( ) Não

9- Uso de analgesia peridural:

( ) Sim Em que momento: ( ) Não 


\begin{tabular}{|c|c|c|c|c|c|c|c|c|c|}
\hline Hora & Palp. & $\overline{\text { BCF }}$ & $\overline{D U}$ & Toque & Ocit. & $\mathbf{P A}$ & $\mathbf{T}$ & Profissional & Observação \\
\hline & & & & & & & & & \\
\hline & & & & & & & & & \\
\hline & & & & & & & & & \\
\hline & & & & & & & & & \\
\hline & & & & & & & & & \\
\hline & & & & & & & & & \\
\hline & & & & & & & & & \\
\hline & & & & & & & & & \\
\hline & & & & & & & & & \\
\hline & & & & & & & & & \\
\hline & & & & & & & & & \\
\hline & & & & & & & & & \\
\hline & & & & & & & & & \\
\hline & & & & & & & & & \\
\hline & & & & & & & & & \\
\hline & & & & & & & & & \\
\hline & & & & & & & & & \\
\hline & & & & & & & & & \\
\hline & & & & & & & & & \\
\hline & & & & & & & & & \\
\hline & & & & & & & & & \\
\hline & & & & & & & & & \\
\hline & & & & & & & & & \\
\hline & & & & & & & & & \\
\hline & & & & & & & & & \\
\hline & & & & & & & & & \\
\hline & & & & & & & & & \\
\hline & & & & & & & & & \\
\hline & & & & & & & & & \\
\hline & & & & & & & & & \\
\hline
\end{tabular}

Legenda: Palp.: palpação, BCF: batimentos cardiofetais, DU: dinâmica uterina, Ocit.: ocitocina, PA: pressão arterial, T: temperatura. 
10- Indicação de Cesárea:

Profissional Em que momento:

Motivo:

\section{III- PARTO}

Hora encaminhada: Condições obstétricas da parturiente:

Hora do parto:

11- Profissional que realizou:

12- Teve supervisão: ( ) Sim De quem? ( ) Não

13- Foi solicitada a presença de outro profissional:

( ) Sim Quem? Em que momento: ( ) Não

14- Local do parto: Posição da mulher no parto:

15- Administração ocitocina:

b) no expulsivo: ( ) Sim ( ) Não $\quad$ d) após dequitação: ( ) Sim ( ) Não

16- Presença de um acompanhante: ( ) Sim O que fez? ( ) Não

17- Oferece líquido (alimentação): ( ) Sim ( ) Não Obs.

18 - Estímulo para puxo quando a dilatação está completa ou quase completa:

( ) Sim ( ) Não

19- Manobra de Kristeller no expulsivo: ( ) Sim ( ) Não Quem fez?

20- Proteção do períneo no expulsivo: ( ) Sim ( ) Não

21- Manejo do pólo cefálico no momento do parto: ( ) Sim ( ) Não

22- Uso de ocitocina na dequitação: ( ) Sim ( ) Não

23- Tração controlada do cordão durante a dequitação: ( ) Sim ( ) Não

24- Momento do clampeamento do cordão:
a) logo após a expulsão do feto:
b) após a parada dos batimentos:

25- Exame da placenta e membranas ovulares: ( ) Sim ( ) Não

26- Contato pele a pele mãe/filho: a) primeira meia hora: ( b) primeira hora: ( )

c) segunda hora: ( ) d) após a segunda hora: ( ) e) não aconteceu: ( )

27- Contato mãe/filho: a) primeira meia hora: ( ) b) primeira hora: ( )

c) segunda hora: ( ) d) após a segunda hora: ( ) e) não aconteceu: ( )

28- Estímulo à amamentação: ( ) Sim ( ) Não

29- Uso de ergometrina após a saída da placenta: ( ) Sim ( ) Não

30- Revisão uterina (exploração manual) após o parto: ( ) Sim ( ) Não 
31- Realizou episiotomia: ( ) Sim ( ) Não

32- Realizou anestesia antes da episiotomia: ( ) Sim Qual? ( ) Não

33- Realizou episiorrafia: ( ) Sim ( ) Não

34- Realizou anestesia antes da episiorrafia: ( ) Sim Qual? ( ) Não

35- Inspeção da vagina e da cérvix para observar lacerações: ( ) Sim ( ) Não

36- Sutura das lacerações: ( ) Sim ( ) Não

37- Realizou anestesia antes da sutura: ( ) Sim Qual? ( ) Não

38- Cuidados com o recém-nascido: profissional:

Quais cuidados foram realizados?

IV- PÓS-PARTO ( $4^{\circ}$ período)

39- Verificou pressão arterial: ( ) Sim ( ) Não

40- Verificou consistência uterina: ( ) Sim ( ) Não

41-Verificou altura uterina: ( ) Sim ( ) Não

42- Verificou sangramento: ( ) Sim ( ) Não

43- Hora que foi encaminhada para enfermaria:

44- Anotação do parto no prontuário: Profissional:

O que foi anotado:

45- Existem equipamentos de emergência:( ) Sim ( ) Não Quem é o responsável:

46- Outras ações/intervenções realizadas:

a)

b)

c)

Situação de emergência:

Descrever: 


\section{APÊNDICE D - Termo de Consentimento Livre e Esclarecido (parturientes)}

Meu nome é Leila Maria Geromel Dotto, sou aluna do Programa de Pós-Graduação Doutorado, da Escola de Enfermagem de Ribeirão Preto - USP, área de concentração: Saúde Pública. Estou desenvolvendo uma pesquisa intitulada: Atenção qualificada ao parto: a realidade da assistência de enfermagem em Rio Branco-AC, para obtenção do título de Doutor em Enfermagem.

Este estudo tem por finalidade conhecer a realidade do atendimento ao trabalho de parto e parto nas maternidades do município de Rio Branco-AC, com especial enfoque no pessoal de enfermagem. Para isto, gostaria de observar as ações/intervenções que os profissionais de saúde desenvolvem enquanto você estiver internada para ter o seu bebê. Você não será identificada em momento algum da pesquisa e poderá a qualquer momento deixar de participar sem prejuízo para o seu atendimento nesta maternidade. Não haverá nenhum custo para você participar da pesquisa.

Esclareço que sua participação será muito importante para que possamos identificar e descrever como a assistência ao parto está sendo desenvolvida nas maternidades de Rio Branco.

Agradeço sua colaboração, coloco-me à disposição para os esclarecimentos que se fizerem necessários, pelo telefone (68) 3223-7778 ou e-mail: leiladotto@uol.com.br.

Obrigada.

Leila Maria Geromel Dotto

Após ter lido e compreendido as informações acima, concordo em participar desta pesquisa e autorizo a utilização dos dados para o presente estudo que poderá ser publicado e utilizado em eventos científicos. 
Anexos

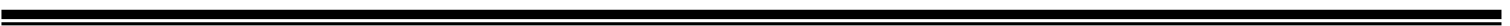




\section{ANEXO A - Competências ${ }^{3}$}

\section{CONFEDERAÇÃO INTERNACIONAL DAS PARTEIRAS}

\section{COMPETÊNCIAS ESSENCIAIS PARA O EXERCÍCIO BÁSICO DA OBSTETRÍCIA/2002}

\section{INTRODUÇÃO}

A Confederação Internacional das Parteiras (ICM) é uma federação de associações de parteiras de 72 nações do mundo. A ICM trabalha de perto com todas as agências da ONU em defesa da Maternidade Segura, estratégias de cuidado de saúde primária para as famílias do mundo, e a definição e preparação da parteira. Mantendo os objetivos da ICM, da Definição Internacional da Parteira da ICM/OMS/FIGO (1992), o Código de Ética Internacional das Parteiras da ICM (1993), a Visão Global da ICM para as Mulheres e a sua Saúde (1996) e pedidos das associações-membro, a ICM tomou a liderança para definir estas competências essenciais para as parteiras.

Ao longo deste documento, o termo "competências" é usado para se referir à ampla declaração que encabeça cada seção, como também ao conhecimento básico, às habilidades e aos comportamentos da parteira, necessários para uma prática segura em qualquer situação. Elas respondem à pergunta: $\mathrm{O}$ que faz uma parteira? e estão baseadas em evidência.

É totalmente compreensível que estas competências podem ser consideradas completas, em algumas áreas do mundo, e mínimas ou insuficientes em outras áreas. Alguns conhecimentos e habilidades estão separados em uma categoria "adicional". Isto permite variação na preparação e prática das parteiras através do mundo, dependendo das necessidades da nação e/ou da comunidade local delas.

Igualmente, reconhece-se que as parteiras recebem conhecimento e habilidades por vários caminhos educacionais, estas competências são escritas para uso genérico pelas parteiras e associações de parteiras responsáveis pela educação e prática da obstetrícia no país ou região. As competências essenciais são diretrizes para quem estiver interessado em desenvolver a educação da parteira, do mesmo modo serve de informação para organismos governamentais e outras esferas que estabelecem normas, e que precisam entender o que é uma parteira, o que uma parteira faz, e como a parteira aprendeu a ser uma parteira.

\footnotetext{
3 Tradução: Leila Maria Geromel Dotto. Revisão: Anne Marie Weissheimer. Texto original em inglês: www.internationalmidwives.org.
} 
É esperado que este documento seja submetido à avaliação contínua, enquanto é usado pelo mundo inteiro, pois as mudanças nas necessidades de cuidados de saúde às mulheres em idade reprodutiva e as suas famílias continuam ocorrendo.

\section{CONCEITOS-CHAVES DA OBSTETRÍCIA}

Os conceitos-chaves da obstetrícia que definem o papel específico das parteiras, promovendo a saúde das mulheres em idade reprodutiva e suas famílias incluem: parcerias com as mulheres para promover seu autocuidado, e a saúde das mulheres, de seus filhos e suas famílias; o respeito à dignidade humana, considerando as mulheres como pessoas possuidoras de todos os direitos humanos; defesa para as mulheres a fim de que suas vozes sejam ouvidas; sensibilidade diante de valores culturais, inclusive trabalhando com as mulheres e provedores de cuidado de saúde, na tentativa de superar práticas culturais que prejudiquem as mulheres e seus bebês; ênfase na promoção de saúde e prevenção de doenças de maneira a ver a gravidez como um evento normal da vida. As parteiras reconhecem que a eqüidade de posição social para as mulheres trará maior impacto na saúde global maternoinfantil, assegurando nutrição adequada, água limpa e serviços de saúde pública; assim elas são comprometidas com a melhoria das condições básicas de vida, como também promovem serviços de obstetrícia competentes.

\section{O ALCANCE DA PRÁTICA}

A extensão da prática obstétrica usada ao longo deste documento é construída pela Definição Internacional da Parteira da ICM/WHO/FIGO (1992). A prática obstétrica inclui o cuidado autônomo da menina, da adolescente e da mulher adulta, antes, durante e depois da gravidez. Isto significa que a parteira dá supervisão necessária, cuidado e aconselhamento às mulheres durante gravidez, o parto e no período pós-parto. A parteira realiza parto sob sua própria responsabilidade e presta cuidados ao recém-nascido. Estes cuidados incluem supervisão de cuidado de saúde primário dentro da comunidade (medidas preventivas); orientação e educação sobre saúde para as mulheres, a família e a comunidade, inclusive orientações para a maternidade; o oferecimento de planejamento familiar; detecção de condições anormais da mãe e da criança; a obtenção de ajuda especializada, quando necessário (consulta ou referência); e a execução de medidas de emergências primária e secundária na ausência do médico. A prática obstétrica desenvolve-se dentro de um sistema de saúde, baseado na comunidade, que pode incluir as parteiras tradicionais, curandeiros tradicionais, outros trabalhadores de saúde comunitária, médicos, enfermeiras e especialistas 
em centros de referência.

\section{O MODELO DE CUIDADO EM OBSTETRÍCIA}

O Modelo de Cuidado em Obstetrícia está baseado na premissa de que gravidez e nascimento são eventos normais de vida. O Modelo de Cuidado em Obstetrícia inclui: monitorar o bem-estar físico, psicológico, espiritual e social da mulher/família ao longo do ciclo reprodutivo; proporcionar à mulher educação individualizada, orientação e cuidado prénatal; dar assistência contínua durante o trabalho de parto, nascimento e pós-parto imediato; oferecer assistência contínua durante todo o período pós-natal, manter um mínimo de intervenções tecnológicas; e identificar e encaminhar as mulheres que requerem atenção em obstetrícia ou outra especialidade. Este modelo de cuidado é centrado na mulher e é a ela que deve prestar contas.

\section{MODELO CONCEITUAL PARA A TOMADA DE DECISÃO EM OBSTETRÍCIA}

As parteiras assumem responsabilidade e respondem por sua prática profissional, aplicando conhecimentos e habilidades atualizados nos cuidados de saúde a cada mulher e família. A segurança e o bem-estar global da mulher são as principais preocupações da parteira. A parteira se esforça para apoiar as escolhas informadas da mulher, no contexto de uma experiência segura. A parteira toma decisão utilizando uma variedade de fontes de conhecimento, este é um processo dinâmico e responde ao estado de saúde variável de cada mulher. As parteiras envolvem as mulheres e suas famílias, em todas as partes do processo de tomada de decisão, desenvolvendo um plano de cuidado para uma gravidez e nascimento saudáveis.

PASSO 1: Colher informação com a mulher, sobre sua história clínica e de seu filho e de qualquer exame laboratorial, de um modo sistemático, para obter uma avaliação completa.

PASSO 2: Identificar problemas atuais ou potenciais, baseando-se na interpretação correta das informações coletadas no Passo 1.

PASSO 3: Desenvolver um plano de cuidado compreensivo para a mulher e sua família, baseado nas necessidades da mulher/criança, de acordo com os dados coletados.

PASSO 4: Realizar o plano de cuidado, atualizá-lo continuamente, dentro de um período de 
tempo adequado.

PASSO 5: Avaliar a eficácia/efetividade do cuidado dado à mulher e sua família, considerando outras alternativas; se fracassar, voltar para o PASSO 1 para coletar mais dados e desenvolver um novo plano.

\section{DECLARAÇÃO ORIENTADORA PARA OS MEMBROS ASSOCIADOS}

As competências essenciais para a prática da obstetrícia básica a seguir estão baseadas nos valores, visão, estratégias e ações usadas por aqueles que assistem as necessidades das mulheres/famílias em idade reprodutiva. As associações-membro são encorajadas a usar esta declaração da ICM sobre competências, seguindo as necessidades de seus próprios países, na educação, na regulamentação e desenvolvimento de modelos de prática para as parteiras, como também em políticas necessárias para fortalecer a obstetrícia.

\section{COMPETÊNCIAS ESSENCIAIS PARA O EXERCÍCIO BÁSICO DA OBSTETRÍCIA MAIO 2002}

\section{CONHECIMENTO GENÉRICO, HABILIDADES E COMPORTAMENTOS DAS CIÊNCIAS SOCIAIS, SAÚDE PÚBLICA E DAS PROFISSÕES DE SAÚDE}

Competência \#1: as parteiras têm o conhecimento e habilidades requeridas das ciências sociais, saúde pública e ética que constituem a base do cuidado de alta qualidade, culturalmente pertinente, apropriado para as mulheres, recém-nascido e famílias, no período reprodutivo.

\section{Conhecimento e habilidades básicas:}

1. Respeitar a cultura local (costumes/hábitos).

2. Práticas de saúde tradicional e moderna (benéfico e prejudicial).

3. Recursos para atenção e transporte (cuidado de emergência).

4. Causas diretas e indiretas de mortalidade e morbidade materna e neonatal na comunidade local.

5. Estratégias para defender e fortalecer (empoderar) as mulheres.

6. Entender os direitos humanos e seus efeitos sobre a saúde.

7. Conhecer os riscos e benefícios dos centros disponíveis para atender aos nascimentos. 
8. Estratégias para defender junto com as mulheres o alcance de vários locais para um nascimento mais seguro.

9. Conhecimento das condições de saúde da comunidade, inclusive a provisão de água, a moradia, os perigos ambientais, os alimentos e as ameaças comuns para saúde.

10. Indicações e procedimentos para ressussitação cardiopulmonar do adulto e da criança.

11. Habilidade para reunir, utilizar e manter os equipamentos e materiais apropriados para a prática.

\section{Conhecimento e habilidades adicionais}

12. Princípios de epidemiologia, sanitarismo, diagnóstico comunitário e estatísticas vitais ou registros.

13. Infra-estruturas de saúde locais e nacionais; como ter acesso a recursos necessários para o cuidado de obstetrícia.

14. Princípios de atenção primária baseada na comunidade, utilizando estratégias de promoção de saúde e de prevenção de doença.

15. Programa de Imunização Nacional (provisão do mesmo ou conhecimento de como ajudar os membros da comunidade a ter acesso aos serviços de imunização).

\section{Comportamento profissional - A parteira:}

1. É responsável e responde pelas decisões clínicas que toma.

2. Mantém os conhecimentos e habilidades atualizados para possibilitar uma prática atual.

3. Usa precauções universais, estratégias de controle de infecção e técnicas higiênicas.

4. Realiza consulta e encaminhamentos apropriados nos cuidados que oferecer.

5. Não emite julgamentos e respeita a cultura.

6. Trabalha em conjunto com as mulheres e as apóia para fazerem escolhas informadas sobre sua saúde.

7. Usa habilidades apropriadas de comunicação.

8. Trabalha de forma colaborativa com outros trabalhadores de saúde para melhorar a prestação de serviços para as mulheres e famílias.

\section{CUIDADO PRÉ-CONCEPCIONAL E MÉTODOS DE PLANEJAMENTO FAMILIAR}

Competência \#2: as parteiras proporcionam educação para saúde de alta qualidade e culturalmente sensível, proporcionam serviços para toda a comunidade para promover uma 
vida familiar saudável, gestações planejadas e uma maternidade/paternidade positivas.

\section{Conhecimento básico de:}

1. Crescimento e desenvolvimento relacionados com a sexualidade, desenvolvimento sexual e atividade sexual.

2. Anatomia e fisiologia masculina e feminina relacionada com a concepção e a reprodução.

3. Normas e práticas culturais relacionadas com a sexualidade, as práticas sexuais e a reprodução.

4. Componentes da história clínica pessoal, familiar e história genética pertinente.

5. Resultados do exame físico e exames laboratoriais investigados para avaliar possibilidade de uma gravidez saudável.

6. Educação para a saúde dirigida à saúde reprodutiva, doenças sexualmente transmitidas (DSTs), HIV/AIDS e sobrevivência infantil.

7. Métodos naturais para espaçar as gestações e outros métodos de planejamento familiar que estejam disponíveis no local e que sejam culturalmente aceitos.

8. Métodos de contracepção de barreira, hormonais, mecânicos, químicos e métodos cirúrgicos de contracepção e indicações para uso.

9. Métodos de aconselhamento para as mulheres que precisam tomar decisões sobre métodos de planejamento familiar.

10. Sinais e sintomas de infecção do trato urinário e de doenças de transmissão sexual comuns na área.

\section{Conhecimento adicional de:}

11. Fatores que envolvem decisões relativas a gestações não planejadas ou não desejadas.

12. Indicadores de doenças agudas e crônicas mais comuns, específicas de uma área geográfica do mundo, e processo de encaminhamento para exame/tratamento.

13. Indicadores e métodos de orientação/encaminhamento para os problemas de relações interpessoais que incluem problemas sexuais, violência doméstica, abuso emocional e negligência física.

\section{Habilidades básicas:}

1. Obter uma história clínica completa.

2. Executar um exame físico com enfoque na condição em que a mulher se apresenta.

3. Solicitar e interpretar exames de laboratório comuns, como por exemplo, hematócrito, 
análise de urina ou exames microscópicos.

4. Usar adequadamente sua habilidade para a educação em saúde e aconselhamentos básicos.

5. Proporcionar métodos de planejamento familiar disponíveis no local e que são aceitos culturalmente.

6. Registrar os achados, incluindo as atividades realizadas e as que necessitam de seguimento.

\section{Habilidades adicionais:}

7. Utilizar microscópio.

8. Oferecer todos os métodos anticoncepcionais disponíveis; de barreira, hormonal, mecânicos, e químicos de contracepção.

9. Realizar ou solicitar a coleta de citologia cervical (teste de Papanicolau).

\section{CUIDADO E ORIENTAÇÃO DURANTE A GRAVIDEZ}

Competência \#3: as parteiras proporcionam um cuidado pré-natal de alta qualidade, preocupadas em otimizar a saúde da mulher durante a gravidez, e isso inclui a detecção precoce, tratamento ou encaminhamento de algumas complicações.

\section{Conhecimento básico de:}

1. Anatomia e fisiologia do corpo humano.

2. Ciclo menstrual e processo de concepção.

3. Sinais e sintomas da gravidez.

4. Como confirmar uma gravidez.

5. Diagnóstico de uma gravidez ectópica e gestação múltipla.

6. Determinação da idade gestacional pela história menstrual, tamanho de útero e/ou dos padrões de crescimento do fundo uterino.

7. Elementos da história clínica.

8. Elementos do exame físico enfocado nas visitas de pré-natal.

9. Resultados normais de exames laboratoriais, definidos segundo as necessidades comuns da área geográfica; exemplo: níveis de ferro, exame de urina para glicose, proteína, cetonas e bactérias.

10. Evolução normal da gravidez: modificações corporais, desconfortos comuns, padrões de crescimento esperados para fundo uterino.

11. Mudanças psicológicas normais na gravidez e impacto da gestação na família. 
12. Preparação de ervas ou outras substâncias não-farmacológicas seguras e disponíveis no local para o alívio de desconfortos comuns da gravidez.

13. Como determinar o bem-estar fetal durante a gravidez, incluindo a freqüência cardíaca fetal e padrões de atividade.

14. Necessidades nutricionais da mulher grávida e do feto.

15. Crescimento e desenvolvimento fetal básico.

16. Necessidades de educação relativa às mudanças corporais normais durante a gravidez, alívio de desconfortos comuns, higiene, sexualidade, nutrição, trabalho dentro e fora de casa.

17. Preparação para o parto, nascimento e maternidade.

18. Preparação da casa/família para receber o recém-nascido.

19. Indicadores do início do trabalho de parto.

20. Como explicar e apoiar o aleitamento materno.

21. Técnicas para relaxamento e medidas disponíveis para o alívio da dor no parto.

22. Efeitos de medicamentos prescritos sobre a gravidez e o feto, drogas proibidas, medicamentos tradicionais e medicamentos sem receita.

23. Efeitos do fumo, uso de álcool e uso de drogas ilícitas na mulher grávida e no feto.

24. Sinais e sintomas de condições que podem colocar em risco a vida da mulher grávida; ex: pré-eclâmpsia, sangramento vaginal, trabalho de parto prematuro, anemia severa.

\section{Conhecimento adicional de:}

25. Sinais, sintomas e indicações para encaminhar a mulher para outro serviço devido a complicações e condições da gravidez. Ex: asma, infecção por HIV, diabete, problemas cardíacos, gravidez prolongada.

26. Efeitos, sobre a gravidez e o feto, de condições crônicas e agudas já citadas.

\section{Habilidades básicas:}

1. Realizar uma história inicial e, em cada consulta pré-natal, dar seguimento.

2. Realizar um exame físico e explicar à mulher os achados.

3. Verificar e avaliar os sinais vitais maternos, inclusive temperatura, pressão sanguínea, e pulso.

4. Avaliar a nutrição materna e sua relação com o crescimento do feto.

5. Exame abdominal completo, incluindo a medida da altura uterina, posição, apresentação e descida do feto.

6. Avaliação do crescimento fetal. 
7. Ausculta da freqüência cardíaca fetal e palpar o útero para determinar padrão de atividade fetal.

8. Realizar exame pélvico, incluindo a medida do tamanho do útero, determinando a adequabilidade das estruturas ósseas.

9. Calcular a data provável do parto.

10. Ensinar as mulheres e famílias sobre sinais de perigo e quando e como contactar com a parteira.

11. Ensinar e demonstrar medidas para diminuir os desconfortos comuns da gravidez.

12. Oferecer um roteiro e preparação básica para o parto, nascimento e maternidade.

13. Identificar as alterações, durante o curso da gravidez, e realizar intervenções apropriadas para:

a. nutrição materna inadequada,

b. crescimento fetal inadequado,

c. pressão sanguínea elevada, proteinúria, presença de edema significante, cefaléias severas, alterações visuais, dor epigástrica associada com pressão sanguínea elevada,

d. sangramento vaginal,

e. gestação múltipla, posição anormal do feto a termo,

f. morte fetal intra-uterina,

g. rotura prematura das membranas.

14. Realizar medida de reanimação de forma competente.

15. Registrar os achados da história clínica, incluindo as atividades realizadas e as que necessitam de seguimento.

\section{Habilidades adicionais:}

16. Orientar as mulheres sobre hábitos de saúde; ex: nutrição, exercício, segurança, parar de fumar.

17. Realizar pelvimetria clínica [avaliação dos ossos da pélvis].

18. Monitorar a freqüência cardíaca fetal com Doppler.

19. Identificar e encaminhar, quando ocorrerem alterações durante o curso da gravidez tais como:
a. retardo do crescimento intra-uterino ou macrossomia fetal,
b. suspeita de poliidrâmnio, diabetes, anomalia fetal (ex: oligúria),
c. resultados anormais de exames laboratoriais,
d. infecções, como doenças sexualmente transmitidas (DSTs), vaginites, infecção do 
trato urinário, infecção das vias respiratórias superiores,

e. Avaliação fetal na gravidez de pós-termo.

20. Tratamento e/ou manejo colaborativo das alterações mencionadas, seguindo as normas locais e os recursos disponíveis.

21. Realizar versão externa na apresentação pélvica.

\section{CUIDADOS DURANTE O PARTO E NASCIMENTO}

Competência \#4: as parteiras proporcionam durante o parto um cuidado de alta qualidade, culturalmente sensível. Conduzem um parto higiênico e seguro e manejam situações de emergência para otimizar a saúde das mulheres e dos recém-nascidos.

\section{Conhecimento básico de:}

1. Fisiologia do parto.

2. Anatomia do crânio fetal, diâmetros críticos e pontos anatômicos importantes.

3. Aspectos psicológicos e culturais do parto e nascimento.

4. Indicadores do início do trabalho de parto.

5. Progressão normal do parto e como usar o partograma ou ferramenta semelhante.

6. Medidas para avaliar o bem-estar fetal durante o parto.

7. Medidas para avaliar o bem-estar materno durante o parto.

8. Processo de descida fetal através da pelve durante o parto e nascimento.

9. Medidas de conforto durante o parto: ex: presença/ajuda da família, posicionamento, hidratação, apoio emocional, métodos não-farmacológicos de alívio da dor.

10. Transição do recém-nascido para a vida extra-uterina.

11. Cuidados físicos do recém-nascido - respiração, calor, alimentação.

12. Promoção de contato pele a pele do recém-nascido com a mãe, quando apropriado.

13. Meios para apoiar e promover o aleitamento materno exclusivo e contínuo.

14. Manejo fisiológico do $3^{\circ}$ período do parto.

15. Indicações para medidas de emergência: ex: placenta retida, distócia de ombro, sangramento uterino por atonia, asfixia neonatal.

16. Indicações para o parto cirúrgico: ex: sofrimento fetal, desproporção cefalopélvica.

17. Indicadores de complicações no parto: sangramento, parada na evolução do parto, distócia de apresentação, eclâmpsia, sofrimento materno, sofrimento fetal, infecção, prolapso de cordão. 
18. Princípios de manejo ativo do $3^{\circ}$ período do parto.

\section{Habilidades básicas:}

1. Realizar uma história específica e controlar os sinais vitais maternos, durante o trabalho de parto.

2. Realizar exame físico direcionado.

3. Fazer exploração/palpação abdominal completa para determinar posição fetal e descida.

4. Avaliar a freqüência e efetividade das contrações uterinas.

5. Realizar um exame pélvico completo e preciso para determinar a dilatação, a descida, a apresentação fetal, variedade de posição, estado das membranas e a adequação da pelve.

6. Acompanhar a evolução do trabalho de parto, usando o partograma ou ferramenta semelhante para registrar.

7. Proporcionar apoio psicológico para a mulher e sua família.

8. Proporcionar hidratação, alimentação e medidas de conforto adequadas durante o trabalho de parto.

9. Proporcionar cuidado para a bexiga.

10. Identificar prontamente anormalidades no parto, com intervenção e/ou encaminhamento apropriado e oportuno.

11. Executar manobras apropriadas para um parto em apresentação cefálica fletida.

12. Manejar uma circular de cordão no parto.

13. Práticar episiotomia, se for necessário.

14. Suturar episiotomia, se necessário.

15. Apoiar o processo fisiológico do $3^{\circ}$ período do parto.

16. Conduzir ativamente o $3^{\circ}$ período do parto incluindo:

a. administração de ocitocina,

b. pinçamento e corte precoce do cordão,

c. tração controlada do cordão.

17. Prevenir a inversão uterina durante o $3^{\circ}$ período do parto.

18. Inspecionar a placenta e membranas para verificar se estão íntegras.

19. Estimar a perda materna de sangue.

20. Inspecionar se ocorreu laceração na vagina e na cérvix.

21. Suturar as lacerações da vagina/períneo e a episiotomia.

22. Manejar a hemorragia pós-parto.

23. Proporcionar um ambiente seguro para promover o vínculo mãe/filho. 
24. Iniciar a amamentação o mais cedo possível, depois do nascimento, e apoiar o aleitamento exclusivo.

25. Realizar exame físico específico no recém-nascido.

26. Registrar os achados, incluindo as atividades realizadas e as que necessitam de seguimento.

\section{Habilidades adicionais:}

31. Executar manobras apropriadas diante de um parto com apresentação pélvica e de face.

32. Injetar anestesia local.

33. Aplicar vácuo-extrator ou fórceps.

34. Manejar distócia de apresentação, distócia de ombro e sofrimento fetal.

35. Identificar e manejar um prolapso de cordão umbilical.

36. Executar remoção manual de placenta.

37. Identificar e suturar lacerações cervicais.

38. Executar compressão interna bimanual do útero para controlar hemorragia.

39. Puncionar veia, colher sangue, fazer testes de hematócrito e hemoglobina.

40. Prescrever e/ou administrar métodos farmacológicos de alívio da dor, quando necessário.

41. Administrar ocitócicos adequadamente para estimular ou induzir o parto ou no tratamento de hemorragia pós-parto.

42. Transferir a mulher que necessita de cuidados adicionais ou de emergência.

\section{CUIDADOS AO PÓS-NATAL DAS MULHERES}

Competência \#5: as parteiras proporcionam à mulher cuidado integral, de alta qualidade, culturalmente sensível, durante o pós-parto.

\section{Conhecimento básico de:}

1. Processo normal de involução e cicatrização depois do parto [incluindo depois de um aborto].

2. Processo de lactação e alterações freqüentes, tais como: ingurgitamento, pouco leite, etc.

3. Nutrição materna, repouso, atividades e necessidades fisiológicas (ex: bexiga).

4. Necessidades nutricionais do recém-nascido.

5. Vínculo e apego pais-filho; ex: como promover relações positivas.

6. Indicadores de subinvolução ex: sangramento uterino persistente, infecção. 
7. Indicações de problemas no aleitamento materno.

8. Sinais e sintomas de condições de risco de vida; ex: sangramento vaginal persistente, retenção urinária, incontinência fecal, pré-eclâmpsia no pós-parto.

\section{Conhecimento adicional de:}

9. Indicadores de determinadas complicações no período pós-natal: ex: anemia persistente, hematoma, embolia, mastite, depressão, tromboflebites.

10. Necessidade de cuidados e orientação, durante e depois do aborto.

11. Sinais e sintomas de complicações de aborto.

\section{Habilidades básicas:}

1. Realizar uma história clínica seletiva, incluindo detalhes da gravidez, parto e nascimento.

2. Realizar exame físico específico para a mãe.

3. Avaliar a involução uterina e a cicatrização das lacerações/suturas.

4. Iniciar e apoiar o aleitamento materno exclusivo.

5. Instruir a mãe sobre autocuidado e os cuidados com o recém-nascido, incluindo o descanso e a nutrição.

6. Identificação dos hematomas, para tratamento e encaminhamento, se necessário.

7. Identificação de infecção materna, para tratamento e encaminhamento, se necessário.

8. Registrar os resultados, incluindo as atividades realizadas e as que necessitam de seguimento.

\section{Habilidades adicionais:}

9. Assessorar a mulher/família sobre sexualidade e planejamento familiar depois do parto.

10. Assessorar e apoiar a mulher no pós-aborto.

11. Esvaziamento de um hematoma.

12. Proporcionar tratamento adequado com antibiótico para infecção.

13. Encaminhar em determinadas complicações.

\section{CUIDADOS COM O RECÉM-NASCIDO (até 2 meses de idade)}

Competência \# 6: as parteiras proporcionam cuidado integral de alta qualidade para o recémnascido saudável, do nascimento até dois meses de idade. 


\section{Conhecimento básico de:}

1. Adaptação do recém-nascido para vida extra-uterina.

2. Necessidades básicas de recém-nascido: respiração, calor, nutrição, apego.

3. Elementos de avaliação das condições imediatas do recém-nascido; ex: sistema de avaliação APGAR para a respiração, freqüência cardíaca, reflexos, tônus muscular e cor.

4. Aparência geral e comportamento do recém-nascido.

5. Crescimento e desenvolvimento normal do recém-nascido e lactente.

6. Particularidades de alguns recém-nascidos normais; ex: “caput”, moldagem da cabeça, manchas mongólicas, hemangiomas, hipoglicemia, hipotermia, desidratação, infecção.

7. Elementos da promoção de saúde e prevenção de doença em recém-nascido e lactente.

8. Necessidade de imunização, riscos e benefícios para o lactente até 2 meses de idade.

\section{Conhecimento adicional de:}

9. Complicações específicas do recém-nascido, ex: icterícia, hematoma, amoldamento anormal do crânio fetal, irritação cerebral, danos não-acidentais, causas de morte súbita infantil.

10. Crescimento e desenvolvimento normal do recém-nascido pré-termo até 2 meses de idade.

\section{Habilidades básicas:}

1. Vias aéreas livres para manter a respiração.

2. Manter o calor corporal, evitando aquecer demais.

3. Avaliar a condição imediata do recém-nascido; ex. APGAR ou outros métodos de avaliação.

4. Executar um exame físico específico no recém-nascido para detectar condições incompatíveis com a vida.

5. Posicionamento da criança para amamentar.

6. Educar os pais sobre sinais de perigo e quando levar a criança para receber cuidado.

7. Iniciar medidas de emergência para dificuldade respiratória (reanimação de recémnascido), hipotermia, hipoglicemia, parada cardíaca.

8. Transferir recém-nascido para receber cuidado de urgência, quando disponível.

9. Registrar os resultados, incluindo as atividades realizadas e as que necessitam de seguimento. 


\section{Habilidades adicionais:}

10. Identificar a idade gestacional.

11. Educar os pais sobre crescimento e desenvolvimento normal, e cuidado da criança.

12. Ajudar os pais a terem acesso aos recursos disponíveis na comunidade para a família.

13. Apoiar pais que vivenciam um nascimento com malformação congênita, perda de gestação, ou morte neonatal.

14. Apoiar pais durante a transferência do recém-nascido.

15. Apoiar pais com nascimentos múltiplos. 


\section{ANEXO B - Comitê de Ética em Pesquisa da EERP/USP}
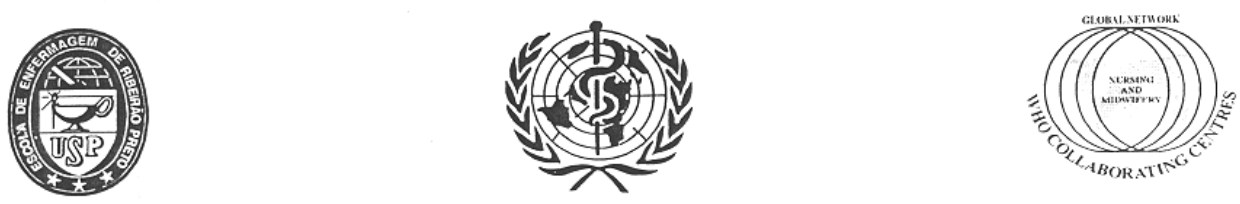

ESCOLA DE ENFERMAGEM DE RIBEIRÃO PRETO - UNIVERSIDADE DE SÃO PAULO CENTRO COLABORADOR DA ORGANIZAÇÃO MUNDIAL DA SAÚDE PARA O DESENVOLVIMENTO DA PESQUISA EM ENFERMAGEM

Avenida Bandeirantes, 3900 - Campus Universitário - Ribeirão Preto - CEP 14040-902 - São Paulo - Brasil FAX: $55-16-633-3271 / 55-16-630-2561$ - TELEFONES: 55 - 16-633-0379/602-3382

\section{COMITÊ DE ÉTICA EM PESQUISA DA EERP/USP}

Of.CEP-EERP/USP - 093/2005

Ribeirão Preto, 28 de julho de 2005

Prezada Senhora,

Comunicamos que o projeto de pesquisa, abaixo especificado, foi analisado e considerado APROVADO pelo Comitê de Ética em Pesquisa da Escola de Enfermagem de Ribeirão Preto da Universidade de São Paulo, em sua $77^{\circ}$ Reunião Ordinária, realizada em 27 de julho de 2005.

Protocolo: $\quad n^{\circ} 0573 / 2005$

Projeto: ATENÇÃO QUALIFICADA AO PARTO: A REALIDADE DA ASSISTÊNCIA DE ENFERMAGEM EM RIO BRANCO - AC

Pesquisadores: Marli Villela Mamede (Orientadora)

Leila Maria Geromel Dotto (Doutoranda)

Em atendimento à Resolução 196/96, deverá ser encaminhado ao CEP - relatório final da pesquisa e a publicação de seus resultados, para acompanhamento, bem como comunicada qualquer intercorrência ou a sua interrupção.

Atenciosamente,

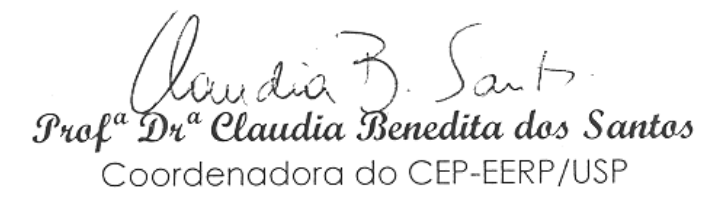

